\title{
STRESS INDICES AT LUG SUPPORTS ON PIPING SYSTEMS
}

\author{
E. C. Rodabaugh \\ W. G. Dodge \\ S. E. Moore
}

\section{OAK RIDGE NATIONAL LABORATORY}




\section{DISCLAIMER}

This report was prepared as an account of work sponsored by an agency of the United States Government. Neither the United States Government nor any agency Thereof, nor any of their employees, makes any warranty, express or implied, or assumes any legal liability or responsibility for the accuracy, completeness, or usefulness of any information, apparatus, product, or process disclosed, or represents that its use would not infringe privately owned rights. Reference herein to any specific commercial product, process, or service by trade name, trademark, manufacturer, or otherwise does not necessarily constitute or imply its endorsement, recommendation, or favoring by the United States Government or any agency thereof. The views and opinions of authors expressed herein do not necessarily state or reflect those of the United States Government or any agency thereof. 


\section{DISCLAIMER}

Portions of this document may be illegible in electronic image products. Images are produced from the best available original document. 
Printed in the United States of America. Available from

National Technical Information Service

U.S. Department of Commerce

5285 Port Royal Road, Springfield, Virginia 22151

Price: Printed Copy \$5.45; Microfiche $\$ 0.95$

This report was prepared as an account of work sponsored by the United States Government. Neither the United States nor the United States Atomic Energy Commission, nor any of their employees, nor any of their contractors, subcontractors, or their employees, makes any warranty, express or implied, or assumes any legal liability or responsibility for the accuracy, completeness or usefulness of any information, apparatus, product or process disclosed, or represents that its use would not infringe privately owned rights. 
ORNL-TM-4211

UC-79, $-79 \mathrm{~h},-79 \mathrm{k}$

Contract No. W-7405-eng-26

Reactor Division

\section{STRESS INDICES AT LUG SUPPORTS ON PIPING SYSTEMS}

E. C. Rodabaugh

Battelle-Columbus Laboratories

W. G. Dodge

Oak Ridge National Laboratory

S. E. Moore

Oak Ridge National Laboratory

MAY 1974

OAK RIDGE NATIONAL IABORATORY

Oak Ridge, Tennessee 37830

operated by

UNION CARBIDE CORPORATION

for the

U.S. ATOMIC ENERGY COMMISSION 
THIS PAGE

\section{WAS INTENTIONALLY LEFT BLANK}


FOREWORD $\ldots \ldots \ldots \ldots \ldots \ldots \ldots \ldots \ldots \ldots \ldots \ldots \ldots \ldots \ldots \ldots \ldots \ldots \ldots$

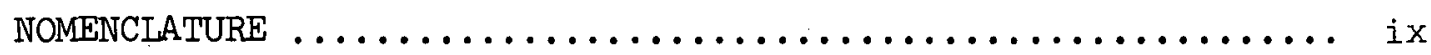

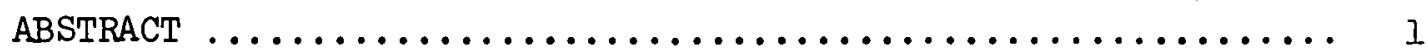

1. INTRODUCTION AND SCOPE $\ldots \ldots \ldots \ldots \ldots \ldots \ldots \ldots \ldots \ldots \ldots$

2. THRUST AND BENDING MOMENT LOADS ..................

Maximum Stress Intensities .................... 7

Comparisons with ASME Boiler Code, Section I,

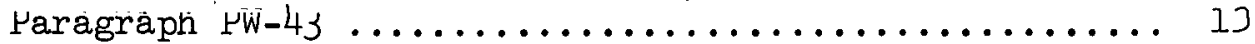

Comparisons with Welding Research Council

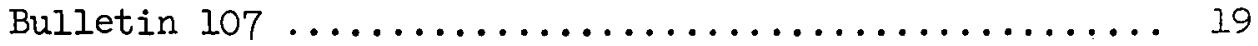

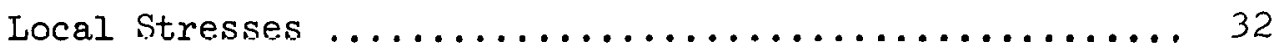

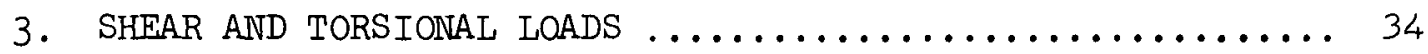

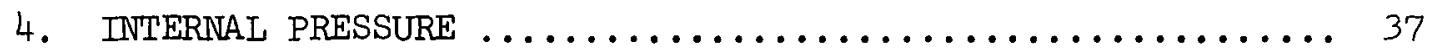

5. THERMAL GRADIENTS ............................. 41

6. CODE USE OF STRESS INDICES ..................... 42

Satisfaction of Primary-Stress-Intensity Limit ....... 43

Satisfaction of Primary-Plus-Secondary Stress-

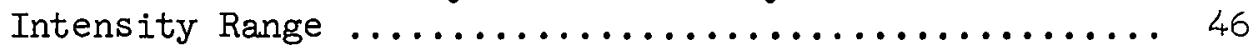

Satisfaction of Peak-Stress-Intensity Range ......... 46

Simplified Elastic-Plastic Discontinuity Analysis ..... 48

7. SUMMARY AND CONCLUSIONS ..................... 49

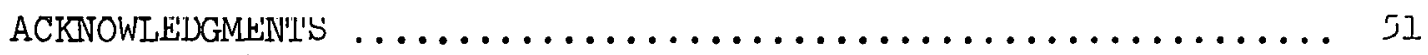

REFERENCES.$\ldots \ldots \ldots \ldots \ldots \ldots \ldots \ldots \ldots \ldots \ldots \ldots \ldots \ldots \ldots \ldots \ldots \ldots$

APPENDIX A: RECOMMENDED ADDITION TO ASME CODE SECTION III

TO COVER STRAIGHT PIPE WITH INTEGRAL STRUCTURAL ATTACHMENTS . . 53

APPENDIX B: DIRECTIONS AND LOCATIONS OF MAXIMUM STRESSES

FOR THRUST AND MOMENT LOADINGS .................... 58

APPENDIX C: EXAMPLE ANALYSIS OF A LUG SUPPORT ........... 70 
THIS PAGE

\section{WAS INTENTIONALLY LEFT BLANK}




\section{FOREWORD}

The work reported here was performed at Oak Ridge National Laboratory (ORVL) and at Battelle-Columbus Laboratories under Union Carbide Corporation Nuclear Division subcontract No. 2913, as part of the ORNL Piping Program - Design Criteria for Piping, Pumps, and Valves - under the direction of W. L. Greenstreet, Associate Head, Solid Mechanics Department, and S. E. Moore, Program Coordinator. The program is funded by the U.S. Atomic Energy Commission (USAEC) as the AEC-supported portion of an AECindustry cooperative effort for the development of design criteria for nuclear-power-plant piping components. This joint effort is coordinated by the Pressure Vessel Research Committee (PVRC) of the Welding Research Council, under the Subcommittee to Develop Stress Indices for Piping, Pumps, and Valves.

Prior reports and open literature publications under the ORNL piping program are listed below.

1. W. L. Greenstreet, S. E. Moore, and E. C. Rodabaugh, "Investigations of Piping Components, Valves, and Pumps to Provide Information for Code Writing Bodies," ASME Paper 68-WA/PTC-6, American Society of Mechanical Engineers, New York, Dec. 2, 1968.

2. W. L. Greenstreet, S. E. Moore, and R. C. Gwaltney, Progress Report on Studies in Applied Solid Mechanics, ORNL-4576 (August 1970).

3. E. C. Rodabaugh, Phase Report No. 115-1 on Stress Indices for Small Branch Connections with External Loadings, ORNL-TM-3014 (August 1970).

4. E. C. Rodabaugh and A. G. Pickett, Survey Report on Structural Design of Piping Systems and Components, TID-25553 (December 1970).

5. E. C. Rodabaugh, Phase Report No. 115-8, Stresses in Out-of-Round Pipe Due to Internal Pressure, ORNL-TM-3244 (January 1971).

6. S. E. Bolt and W. L. Greenstreet, "Experimental Determination of Plastic Collapse Loads for Pipe Elbows," ASME Paper 71-PVP-37, American Society of Mechanical Engineers, New York, May 1971.

7. G. H. Powell, R. W. Clough, and A. N. Gantayat, "Stress Analysis of B16.9 Tees by the Finite Element Method," ASME Paper 71-PVP-40, American Society of Mechanical Engineers, New York, May 1971.

8. J. K. Hayes and B. Roberts, "Experimental Stress Analysis of 24-Inch Tees," ASME Paper 71-PVP-28, American Society of Mechanical Engineers, New York, May 1971. 
9. J. M. Corum et al., "Experimental and Finite Element Stress Analysis of a Thin-Shell Cylinder-to-Cylinder Model," ASME Paper 71-PVP-36, American Society of Mechanical Engineers, New York, May 1971.

10. W. L. Greenstreet, S. E. Moore, and J. P. Callahan, Second Annual Progress Report on Studies in Applied Solid Mechanics (Nuclear Safety), ORNL-4693 (July 1971).

11. J. M. Corum and W. L. Greenstreet, "Experimental Elastic Stress Analysis of Cylinder-to-Cylinder Shell Models and Comparisons with: Theoretical: Predictions," Paper. No. G2/5, First International Conference on Structural Mechanics in Reactor Technology, Berlin, Germany, Sept: $20 \cdots 24,1971$.

12. R. W. Clough, G. H. Powell, and A. N. Gantayat, "Stress Analysis of B16.9 Tees by the Finite Element Method," Paper No. F4/7, First International Conference on Structural Mechanics in Reactor. Technology, Berlin, Germany, Sept. 20-24, 1971.

13. R. L. Johnson, Photoelastic Determination of Stresses in ASA B16.9 Tees, Research Report 71-9E7-PHOTO-R2, Westinghouse Research Laboratory (November 1971).

14. E. C. Rodabaugh and S. E. Moore, Phase Report No. 115-10 on Comparisons of Test Data with Code Methods for Fatigue Evaluations, ORNLTM-3520 (November 1971).

15. W. G. Dodge and S. E. Moore, Stress Indices and Flexibility Factors for Moment Loadings on Elbows and Curved Pipe, ORNL-TM-3658 (March $1972)$.

16. J. E. Brock, Elastic Buckling of Heated, Straight-Line Piping Configurations, ORNL-TM-3607 (March 1972).

17. J. M. Corum et al., Theoretical and Experimental Stress Analysis of ORNL Thin-Shel1 Cylinder-to-Cylinder Model No. 1, ORNL-4553 (October 1972).

18. W. G. Dodge and J. E. Smith, A Diagnostic Procedure for the Evaluation of Strain Data from a Linear Elastic Test, ORNL-TM-3415 (November 1.72).

19. W. G. Dodge and S. E. Moore, "Stress Indices and Flexibility Factors for Moment Loadings on Elbows and Curved Pipe," Welding Research Council Bulletin 179, December 1972.

20. W. L. Greenstreet, S. E. Moore, and J. P. Callahan, Third Annual Progress Report on Studies in Applied Solid Mechanics (Nuclear Safety), ORNL-4821 (December 1972). 
21. W. G. Dodge and S. E. Moore, ELBdW: A Fortran Program for the Calculation of Stresses, Stress Indices, and Flexibility Factors for Elbows and Curved Pipe, ORNL-TM-4098 (April 1973).

22. W. G. Dodge, Secondary Stress Indices for Integral Structural Attach- ments to Straight Pipe, ORNL-TM-3476 (June 1973). 
THIS PAGE

WAS INTENTIONALLY

LEFT BLANK 
$A_{\ell}=4 L_{1} L_{2}=$ loaded area (base of lug)

$A_{p}=2 \pi r t=$ cross-sectional area of pipe

$\mathrm{B}=$ stress index for sustained loads

$\mathrm{B}_{\mathrm{T}}, \mathrm{B}_{\mathrm{L}}, \mathrm{B}_{\mathrm{C}}=$ stress indices for radial thrust, longitudinal moment, and circumferential moment loadings respectively

$\mathrm{B}_{1}, \mathrm{~B}_{2}=$ stress indices as defined by the Code*

$\mathrm{C}=$ stress index for primary-plus-secondary stresses

$\mathrm{C}_{\mathrm{T}}, \mathrm{C}_{\mathrm{L}}, \mathrm{C}_{\mathrm{C}}=$ stress indices for radial thrust, longitudinal moment, and circumferential moment loadings respectively; the normalizing stress is the nominal stress at base of the lug

$\mathrm{C}_{\mathrm{T}}^{*}, \mathrm{C}_{\mathrm{L}}^{*}, \mathrm{C}_{\mathrm{C}}^{*}=$ analogous to $\mathrm{C}_{\mathrm{T}}$, etc., except that the normalizing stress is the nominal stress in the pipe

$\mathrm{C}_{1}, \mathrm{C}_{2}, \mathrm{C}_{3}, \mathrm{C}_{3}^{\prime}=$ stress indices as defined.by the Code

$\mathrm{D}_{0}=$ outside diameter of the pipe

$\mathrm{E}$ = modulus of elasticity as defined by the Code

$\mathrm{K}$ = stress index for local stresses

$\mathrm{K}_{\mathrm{e}}$ = fatigue evaluation factor defined by the Code in Paragraph NB-3653.6

$\mathrm{K}_{\ell}=$ stress index for local stresses at lug fillet welds

$\mathrm{K}_{1}, \mathrm{~K}_{2}, \mathrm{~K}_{3}=$ peak stress indices as defined by the Code

$L_{1}=$ one-half the width of the loaded area in the circumferential direction

$L_{2}=$ one-half the length of the loaded area in the longitudinal direction

$L=$ one-half the length of a simply supported cylindrical shell

$I_{a}, I_{b}, L_{c}, L_{d}=\underset{t o r}{l u m e n s i o n s ~ u s e d ~ i n ~ d e f i n i n g ~ i n d i c e s ~ f o r ~ s h e a r ~ a n d ~}$

$\mathrm{M}_{i}, \mathrm{M}_{i}^{*}=\underset{\text { analysis }}{\operatorname{magnitudes}}$ of moment-vector ranges as used in the Code's design

$\mathrm{M}_{\mathrm{L}}, \mathrm{M}_{\mathrm{C}}, \mathrm{M}_{\mathrm{T}}=\underset{\text { longitudinal, circumferential, and torsional moments respec- }}{\text { tively }}$

$\overline{\mathrm{M}}_{\mathrm{T}}=$ torsional-moment-load term $\mathrm{M}_{\mathrm{L}}^{*}, \mathrm{M}_{\mathrm{C}}^{*}, \mathrm{M}_{\mathrm{T}}^{*}=\underset{\text { respectively }}{\text { range }}$ of longitudinal, circumferential, and torsional maments

$\overline{\mathrm{M}}_{\mathrm{T}}^{*}$ = range of $\overline{\mathrm{M}}_{\mathrm{T}}$

*Code, as used in this report, refers to ASME Boiler and Pressure Vessel Code, Section III, Nuclear Power Plant Components; see Ref. 1. 
$\mathrm{P}=$ design pressure as specified by the Code

$\mathrm{P}_{\mathrm{O}}=$ range of operating pressure according to the Code

$\mathrm{p}=$ internal pressure

$Q_{1}, Q_{2}=$ circumferential and longitudinal shear forces respectively

$Q_{1}^{*}, Q_{2}^{*}=$ range of circumferential and longitudinal shear forces respectively

$r$ = mean pipe radius

$\mathrm{S}_{\text {alt }}=$ alternating stress intensity as defined by the Code.

$S_{\mathrm{e}}=$ expansion stress intensity

$\mathrm{S}_{l}=$ nominal stress at the base of the lug

$=\mathrm{W} / 4 \mathrm{~L}_{1} \mathrm{~L}_{2}$ for radial thrust load

$=6 \mathrm{M}_{\mathrm{L}} / 8 \mathrm{~L}_{1} \mathrm{~L}_{2}$ ? for longitudinal moment load

$=6 \mathrm{M}_{\mathrm{C}} / 8 \mathrm{~L}_{1}{ }^{2} \mathrm{~L}_{2}$ for circumferential moment load

$\mathrm{S}_{\mathrm{n}}=$ primary-plus-secondary stress-intensity range

$S_{p}=$ peak-stress-intensity range

$t=$ pipe wall thickness

$\mathrm{T}_{\ell}=$ average temperature of $\mathrm{lug}$

$\dot{\mathrm{T}}_{\mathrm{W}}=$ average temperature of pipe

$\mathrm{W}$ = radial thrust load

$W^{*}=$ range of radial load

$\mathrm{x}=$ axial coordinate.

$\mathrm{Z}=$ section modulus

$z_{p}=\pi r^{2} t$, section modulus of the pipe

$\mathrm{Z}_{\ell_{\mathrm{L}}}^{\mathrm{P}}=8 \mathrm{~L}_{1} \mathrm{~L}_{2}{ }^{2} / 6$, lug section modulus for longitudinal moment loading $\mathrm{M}_{\mathrm{L}}$

$\mathrm{Z}_{\ell \mathrm{C}}=8 \mathrm{~L}_{1}{ }^{2} \mathrm{~L}_{2} / 6$, lug section modulus for circumferential moment loading $\mathrm{M}_{\mathrm{C}}$

$\alpha=$ coefficient of thermal expansion

$\beta_{1}=L_{1} / r$, nondimensional parameter perpendicular to the pipe axis

$\dot{\beta}_{2}=\bar{L}_{2} / r$, nondimensional parameter parallel with the pipe axis

$\gamma=r / t$, radius-to-thickness ratio of cylindrical shell

$\varnothing=$ circumferential coordinate

$\sigma=$ normal otres

$T=$ shear stress 
STRESS INDICES AT LUG SUPPORTS ON PIPING. SYSTEMS

E. C. Rodabaugh W. G. Dodge

S. E. Moore

\begin{abstract}
Stress indices and the appropriate simplified design formulas are developed for analyzing integral lug attachments on straight pipe according to the philosophy of Section III of the ASME Boiler and Pressure Vessel Code for Class I Piping Systems. Indices are developed for the evaluation of primary stresses, primary-plus-secondary stresses, and peak stresses due to internal pressure in the pipe; for radial thrust and transverse shear forces and torsional and bending moment loads acting on the lug; and for a thermal gradient between the pipe and the lug. The indices for thrust and bending moment loads are based on an extensive parameter study and are represented by simple formulas that may be used directly by designers and/ or incorporated into codes and standards. From comparisons with other methods of analysis these formulas are considered to be more accurate and easier to use. Indices for the other loadings are based in part on strength-of-materials theory and information in the literature. Specific recommendations are made for incorporating the stress indices and design formulas into the ASME Code. As an example, a simple pipe support design is analyzed using the recommended formulas.

Key words: stress indices, stress analysis, pipe supports, pipe attachments, straight pipe, piping code, ASME BPV Section III, lugs, lug supports, nuclear piping, pressure vessel code, ORNL piping program.
\end{abstract}

1. INTRODUCTION AND SCOPE

The ASME Boiler and Pressure Vessel Code, Section III, Nuclear Power Plant Components ${ }^{1}$ (hereinafter referred to as the Code) includes a "simplified" method of design analysis for piping components (Subsubarticle $\mathrm{NB}-3650) *$ which makes use of stress indices. The method uses three types

* References to articles, subarticles, paragraphs, tables, or figures from the Code are identified by number (e.g., NB-xxxx), as appropriate. 
of indices ( $B, C$, and $K$ ), which are related to the three categories of Code-allowable stresses: primary, primary-plus-secondary, and peak stresses, respectively, in conjunction with five rather simple equations. In the Code the design formulas are given as Eqs. (9) to (14) in Paragraphs NB-3652 and NB-3653, and stress indices for many commonly used piping components are given in Table NB-3683.2-1. The Code equations are reproduced here in Table 1.* Reference to these equations as Eqs. (C9)(C14) is made throughout this report when referring to Code equations in order to avoid confusion with numbered equations of the text.

To the extent that stress indices are provided for the particular piping component and loading, the Code-analysis method is a relatively simple way to check a piping design for compliance with Code requirements. At present, however, stress indices are not provided for lugs or other types of pipe supports. The purpose of this report is to develop stress indices for points on piping systems that are supported or restrained by lugs which are integral with the pipe, that is, attached with full-penetration welds.

Three types of loadings are involved in the analysis: (1) mechanical loads, such as thrust, shear, and bending moments; (2) internal pressure; and (3) thermal gradients. Conceptually $B, C$, and $K$ stress indices could be developed for each of the loadings and ad, ted to Table NB-3683.2-1 for direct use in Eqs. (C9)-(C14). However, since this table and its footnotes are already quite lengthy and involved and since the evaluation of stresses at lugs involves an almost independent set, of definitions, the approach taken here is to modify the existing Code equations hy a.tत= ing new terms, specifically for integral lugs. The modified equations take the generic form shown in Table 2, where the new terms are identified by the subscript "lug." Definitions for these additions in terms of appropriate $\mathrm{B}_{\ell}, \mathrm{C}_{\ell}$, and $\mathrm{K}_{\ell}$ stress indices for each of the three types of loadings are developed in Sections 2 to 5. Their application, as a supplement to the present Code analysis, is discussed in section 6, with specific recommendations for Code use given in Appendix A.

*Table 1 is presented with appropriate definitions given in the nomenclature, but without the accompanying footnotes, qualifications, or cross references given in the Code. 
Table 1. Equations ${ }^{a}$ for the simplified designanalysis procedures of the Code

$B_{1} \frac{P D_{O}}{2 t}+B_{2} \frac{D_{O}}{2 I} M_{i} \leq 1.5 S_{m}$

$S_{n}=C_{1} \frac{P_{0} D_{0}}{2 t}+C_{2} \frac{D_{0}}{2 I} M_{i}$

$+\frac{1}{2(1-v)} E \alpha\left|\Delta T_{1}\right|+C_{3} E_{a b}\left|\alpha_{a} T_{a}-\alpha_{b} T_{b}\right| \leq 3 S_{m}$

$S_{p}=K_{1} C_{1} \frac{P_{0} D_{0}}{2 t}+K_{2} C_{2} \frac{D_{0}}{2 I} M_{i}$

$+\frac{1}{2(1-v)} K_{3} E \alpha\left|\Delta T_{1}\right|+K_{3} C_{3} E_{a b}\left|\alpha_{a} T_{a}-\alpha_{b} T_{b}\right|$

$$
+\frac{1}{1-v} E \alpha\left|\Delta \mathrm{T}_{2}\right|
$$

$S_{e}=C_{2} \frac{D_{0}}{2 I} M_{i}^{*} \leq 3 S_{m}$

$C_{1} \frac{P_{O} D_{0}}{2 t}+C_{2} \frac{D_{o} M_{i}}{2 I}+C_{3}^{\prime} E_{a b}\left|\alpha_{a} T_{a}-\alpha_{b} T_{b}\right| \leq 3 S_{m}$

$S_{\text {alt }}=\frac{K_{E}}{2} S_{p}$

abstracted from Paragraph NB-3650 of the Code; see Nomenclature and the Code for symbol definitions. 
Table 2. Modified stress index equations for the design analysis of pipe with integral attachments remote from other discontinuities ${ }^{2}$

Primary stress-intensity limit:

$$
B_{1} \frac{P_{0}}{2 t}+B_{2} \frac{D_{0}}{2 I} M_{i}+\left(P_{L}+P_{b}\right)_{1 u g} \leq 1.5 S_{m}
$$

Primary-plus-secondary stress-intensity-range limit:

$$
S_{n}=C_{1} \frac{P_{0} D_{0}}{2 t}+C_{2} \frac{D_{0}}{2 I} M_{i}+\frac{1}{2(1-v)} E \alpha\left|\Delta T_{1}\right|+\left(S_{n}\right)_{1 u g} \leq 3 S_{m}
$$

Peak stress-intensity range:

$$
\begin{aligned}
S_{p}=K_{1} C_{1} \frac{P_{0} D_{0}}{2 t}+ & K_{2} C_{2} \frac{D_{0}}{2 I} M_{i} \\
& +\frac{1}{2(1-v)} K_{u_{3}} E \alpha\left|\Delta T_{1}\right|+\frac{1}{1-v} E \alpha\left|\Delta T_{2}\right|+\left(S_{p}\right)_{\text {lug }}
\end{aligned}
$$

Nominal expansion-stress limit:

$$
S_{e}=C_{2} \frac{D_{0}}{2 I} M_{i}^{*} \leq 3 S_{m}
$$

Nominal primary-plus-secondary membrane-plus-bending stressintensity-range limit (excluding thermal-bending and thermal-expansion stresses):

$$
c_{1} \frac{P_{\theta} D_{\theta}}{2 t}+c_{2} \frac{D_{u}}{2 I} M_{i} \leq 3 S_{m}
$$

Alternating stress intensity:

$$
s_{\text {alt }}=K_{e} \frac{s_{p}}{2}
$$

${ }^{a}$ Since the intended application is for lugs remote from other discontinuities, the term $\left|\alpha_{a} T_{a}-\alpha_{b} T_{b}\right|$ in Eqs. (C10), (Cll), and (C13) is
zero. 
Maximum stress intensities induced in the pipe-lug component by the different types of loading are discussed in Sections 2 to 5 . Stress indices for thrust and bending moment loads applied to the lug are discussed in Section 2 based on the analysis and numerical results given by Dodge 2 for the maximum surface stresses (membrane plus bending) in the pipe. The primary-plus-secondary stress indices (C-type indices) developed in Ref. 2 are renormalized to conform with the equations of Table 1. The maximum membrane and surface stresses from the numerical parameter study are tabulated in Appendix B since they were not reported in Ref. 2. Local stresses and the corresponding K-type stress indices for thrust and bending moment loads are also discussed in Section 2.

In addition to the stress-index analysis method for integral lug attachments given in this report, there are two methods that are widely used in design: (1) the design equations prescribed in Paragraph $\mathrm{PW}-43$ of the ASME Boiler and Pressure Vessel Code, Section I, Power Boilers, ${ }^{3}$ referred to herein as the PW- 43 method, and (2) the analysis presented in Welding. Research Council Bulletin 107 (WRC-107 method). 4 Since both of these methods are concerned only with thrust and bending moment loads, comparative results with the indices developed in Section 2 are also given in this section. Conclusions drawn from these comparisons indicate that the PW-43 method gives maximum allowable loadings which are comparable with the results from the stress-index analysis, although the applicable range for the PW-43 method is limited. Comparisons with the WRC-107 method show that the results are similar for square lugs but that for long rectangular lugs the WRC-107 method may be incorrect.

Stresses due to transverse shear and torsional moment loads on the lug are discussed in Section 3. The analyses are based on rather simple strength-of-materials assumptions that are believed to be conservalive and therefore adequate for defining stress indices for Code use. An example calculation for the design of shear lug supports for a vertical pipe section is given in Appendix $C$.

Calculated stresses due to internal pressure, discussed in Section 4, are based on an analysis of a cylindrical shell with a solid circular insert. For square or rectangular lugs, approximations are introduced 
which should give conservative results, although further study is needed to verify this point.

Stresses due to temperature differences between the lug and the pipe are discussed in Section 5. Here again the analytical model is only an approximation, and a more rigorous analysis would be desirable although the results given here are believed to be conservative.

All the basic analyses used in this report are concerned with the stresses in the pipe and not in.the lug itself. A portion of the lug, however, is included within the jurisdiction of the cote rules given in , Subarticle NB-3600 Piping Design, whereas the remainder of the lug would be covered by Subsection $\mathrm{NF}$, Component Supports.* For the type of lugs considered in this report, the lug-pipe interface and the portion of the lug within a distance of $0.353 \mathrm{r}$ from the surface of the pipe, where $r$ is one-half the maximum cross-sectional dimension of the lug, are within the jurisdiction of NB-3600. With relatively simple modifications and/or restrictions, the equations developed in this report for calculating stresses in the pipe wall due to thrust, shear, and moment loads on the lug can also be used to evaluate the adequacy of the lug-pipe interface. These modifications and restrictions are therefore included as appropriate. The development of stress indices given here applies basically to rectangulär integral lugs on straight pipe remote from other discontinu1ties.

In piping systems, it may also be desirable to place lugs on elbows or tees. While the indices developed here may (with appropriate modifications) be applicable to such components, we believe that, surh extensinns should not be attempted until after the present approach to the integrallug problem has been studied by potential users.

*According to the December 1972 draft of Subsection NF, this boundary is established in Subarticle NF-1000, Paragraph NF-1512. 
2. THRUST AND BENDING MOMENT ' LOADS

\section{Maximum Stress Intensities}

Stress indices developed by Dodge ${ }^{2}$ for calculating the maximum surface stresses (membrane plus bending) in straight circular pipe due to thrust and moment loadings at lug attachments as indicated in Fig. 1 are
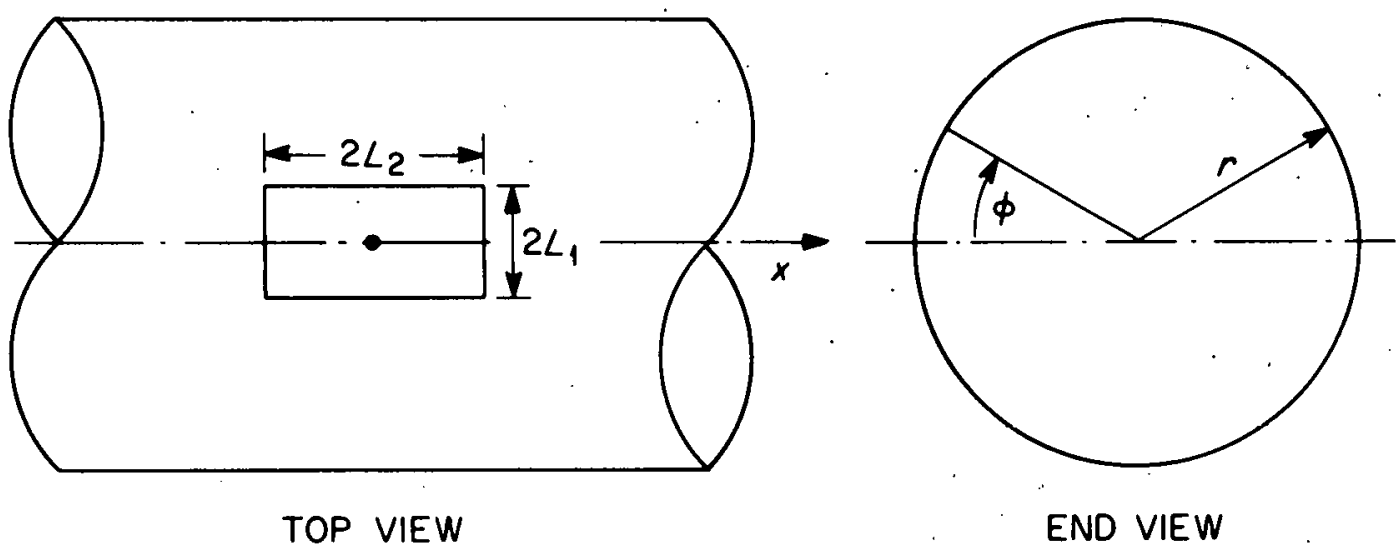

END VIEW
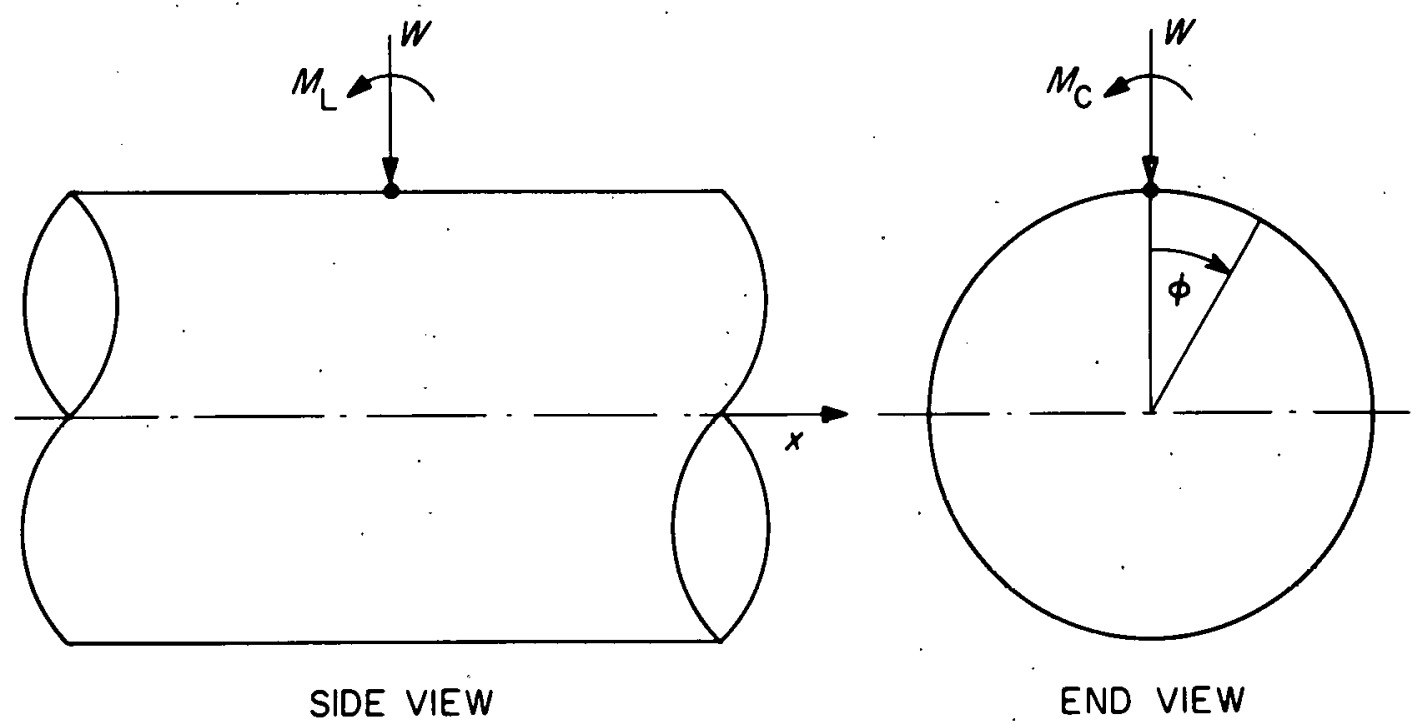

Fig. 1. Coordinate system and positive directions for loadings. 
given by

$$
\begin{aligned}
& C_{T}^{*}=12.0(r / t)^{0.64} \eta^{1.54}, \\
& C_{L}^{*}=1.2(r / t)^{0.74} \eta^{4.74}, \\
& C_{C}^{*}=1.8(r / t)^{0.90} \eta^{3.40},
\end{aligned}
$$

where $C_{T}^{*}$ is for a radial thrust load, $C_{L}^{*}$ is for a longitudinal moment load, and $\mathrm{C}_{\mathrm{C}}^{*}$ is for a circumferential moment load acting on the lug. The nondimensional parameter $\eta$ is given by

$$
\eta=-\left(X_{1} \cos \theta+Y_{1} \sin \theta\right)-\frac{1}{A_{0}}\left(X_{1} \sin \theta-Y_{1} \cos \theta\right)^{2},
$$

where $\theta$ is a constant and $X_{1}$ and $Y_{1}$ are given in terms of the constants $X_{O}$ and $Y_{O}$ and the nondimensional width and length parameters $\beta_{1}$ and $\beta_{2}$ :

$$
\begin{aligned}
& X_{1}=X_{0}+\log _{10} \beta_{1}, \\
& Y_{1}=Y_{0}+\log _{10} \beta_{12} .
\end{aligned}
$$

Here $\beta_{1}=L_{1} / r$ is one-half the width of the loaded area in the circumferential direction divided by the mean pipe radius $r$ and $\beta_{2}=L_{r} / r$ is onehalf the length of the loaded area in the longitudinal direction divided by $r$.

Appropriate numerical values for the constants $A_{0}, \theta, X_{0}$, and $Y_{0}$ are tabulated below for each of the three different types of Ioad.

\begin{tabular}{lcccr}
\multicolumn{1}{c}{ Load } & $\mathrm{A}_{\mathrm{O}}$ & $\theta$ & $\mathrm{X}_{\mathrm{U}}$ & \multicolumn{1}{c}{$\mathrm{Y}_{\mathrm{O}}$} \\
\hline Thrust & 2.2 & $40^{\circ}$ & 0 & 0.05 \\
Longitudinal moment & 2.0 & $50^{\circ}$ & -0.45 & -0.55 \\
Circumferential moment & 1.8 & $40^{\circ}$ & -0.75 & -0.60
\end{tabular}

Maximum stress intensities in the pipe $\bar{\sigma}_{T}, \bar{\sigma}_{L}$, and $\bar{\sigma}_{C}$ corresponding to the thrust and moment loadings $W, M_{L}$, and $M_{C}$ on the lug are then given 
by the following stress-index equations in terms of the pipe dimensions:

$$
\begin{aligned}
& \bar{\sigma}_{\mathrm{T}}=\mathrm{C}_{\mathrm{T}}^{*} \mathrm{~W} / \mathrm{A}_{\mathrm{p}}, \\
& \bar{\sigma}_{\mathrm{L}}=\mathrm{C}_{\mathrm{L}}^{*} \mathrm{M}_{\mathrm{L}} / \mathrm{z}_{\mathrm{p}}, \\
& \bar{\sigma}_{\mathrm{C}}=\mathrm{C}_{\mathrm{C}}^{*} \mathrm{M}_{\mathrm{C}} / \mathrm{z}_{\mathrm{p}},
\end{aligned}
$$

where $A_{p}$ is the cross-sectional area of the pipe and $z_{p}$.is the section modulus of the pipe. This form of stress index has certain advantages in that, for moment loading, the nominal stresses $\left(M_{L} / z_{p}\right)$ and $\left(M_{C} / z_{p}\right)$ are the same as used in the Code for moments acting on the pipe cross section. However, as indicated in the Introduction, it appears desirable to consider the additional stresses in the pipe caused by the lug separately from the stresses presently covered by the Code. With this approach we may change the normalizing base of Dodge's $\mathrm{C}^{*}$-type indices to the nominal stresses in the lug. Thus $\mathrm{C}_{\mathrm{T}}, \mathrm{C}_{\mathrm{L}}$, and $\mathrm{C}_{\mathrm{C}}$ may be defined as

$$
\begin{aligned}
& \mathrm{C}_{\mathrm{T}}=\bar{\sigma}_{\mathrm{T}} /\left(\mathrm{W} / \mathrm{A}_{\ell}\right), \\
& \mathrm{C}_{\mathrm{L}}=\bar{\sigma}_{\mathrm{L}} /\left(\mathrm{M}_{\mathrm{L}} / \mathrm{z}_{\ell L}\right), \\
& \mathrm{C}_{\mathrm{C}}=\bar{\sigma}_{\mathrm{C}} /\left(\mathrm{M}_{\mathrm{C}} / \mathrm{z}_{\ell \mathrm{C}}\right),
\end{aligned}
$$

where $A_{\ell}=4 \mathrm{~L}_{1} \mathrm{~L}_{2}$ is the cross-sectional area of the lug at the pipe surface, $Z_{\ell L}=(4 / 3) L_{1} L_{2}{ }^{2}$ is the section modulus of the lug at the pipe surface for an applied moment $M_{L}$, and $Z_{\ell C}=(4 / 3) L_{1}{ }^{2} L_{2}$ is the section modulus of the lug at the pipe surface for an applied moment $M_{C}$. Conversion from the $\mathrm{C}^{*}$ indices to the $\mathrm{C}$ indices is obtained by the following relationships:

$$
\begin{aligned}
& C_{T}=C_{T}^{*}\left(A_{\ell} / A_{p}\right)=C_{T}^{*}\left[4 L_{1} L_{2} /(2 \pi r t)\right]=C_{T}^{*}\left(2 \beta_{1} \beta_{2} \gamma / \pi\right), \\
& C_{L}=C_{L}^{*}\left(z_{\ell L} / z_{p}\right)=C_{L}^{*}\left[8 \mathrm{~L}_{1} L_{2}{ }^{2} /\left(6 \pi r^{2} t\right)\right]=C_{L}^{*}\left[4 \beta_{1} \beta_{2}{ }^{2} \gamma /(3 \pi)\right], \\
& C_{C}=C_{C}^{*}\left(z_{\ell} / z_{p}\right)=C_{C}^{*}\left[8 \mathrm{I}_{1}{ }^{2} L_{2} /\left(6 \pi r^{2} t\right)\right]=C_{C}^{*}\left[4 \beta_{1}{ }^{2} \beta_{2} \gamma /(3 \pi)\right],
\end{aligned}
$$

where $\gamma=r / t$ is the radius-to-thickness ratio of the pipe. 
Numerical values of $\mathrm{C}_{\mathrm{T}}, \mathrm{C}_{\mathrm{L}}$, and $\mathrm{C}_{\mathrm{C}}$ are given in Tables 3 to 5 respectively. Table 3, for thrust load, gives the ratios of the maximum primary-plus-secondary stress intensity in the pipe to the nominal compressive (or tensile) stress in the lug at the pipe surface. (See Fig. I for assumed positive load directions.) Reversing the direction of the load reverses the sign of all stresses. Tables 4 and 5, for longitudinal and circumferential moment loadings $\mathrm{M}_{L}$ and $\mathrm{M}_{C}$, respectively, give the ratios of the maximum primary-plus-secondary stress in the pipe to the nominal

Table 3. Stress indices $\mathrm{C}_{\mathrm{T}}$ for thrust loading

\begin{tabular}{|c|c|c|c|c|c|c|}
\hline \multicolumn{2}{|c|}{ Shape parameter } & \multicolumn{5}{|c|}{ Radius-to-thickness $(\gamma)$ ratio } \\
\hline$\beta_{1}$ & $\beta_{\dot{2}}$ & 5 & 10 & 20 & $40^{\circ}$ & 80 \\
\hline 0.05 & $\begin{array}{l}0.05 \\
0.1 \\
0.2 \\
0.3 \\
0.4 \\
0.5\end{array}$ & $\begin{array}{l}0.66 \\
1.11 \\
1.72 \\
2.12 \\
2.38 \\
2.55\end{array}$ & $\begin{array}{l}2.05 \\
3.44 \\
5.36 \\
6.61 \\
7.43 \\
7.05\end{array}$ & $\begin{array}{l}6.30 \\
10.7 \\
16.7 \\
20.6 \\
23.2 \\
21.8\end{array}$ & $\begin{array}{l}19.9 \\
33.5 \\
52.1 \\
64.2 \\
72.2 \\
77.2\end{array}$ & $\begin{array}{r}62.1 \\
104.0 \\
162.0 \\
200.0 \\
225.0 \\
2111.0\end{array}$ \\
\hline 0.1 & $\begin{array}{l}0.05 \\
0.1 \\
0.2 \\
0.3 \\
0.4\end{array}$ & $\begin{array}{l}1.02 \\
1.74 \\
2.74 \\
3.38 \\
3.80\end{array}$ & $\begin{array}{c}3.19 \\
5.44 \\
8.53 \\
10.5 \\
11.8\end{array}$ & $\begin{array}{l}9.95 \\
16.9 \\
26.6 \\
32.8 \\
36.9\end{array}$ & $\begin{array}{r}31.0 \\
52.8 \\
82.9 \\
102.0 \\
115.0\end{array}$ & $\begin{array}{r}96.7 \\
165.0 \\
258.0 \\
319.0 \\
358.0\end{array}$ \\
\hline $0 . ?$ & $\begin{array}{l}0.05 \\
0.1 \\
0.2 \\
0.3\end{array}$ & $\begin{array}{l}1.46 \\
2.52 \\
3.96 \\
4.87\end{array}$ & $\begin{array}{r}4.54 \\
7.84 \\
12.4 \\
15.2\end{array}$ & $\begin{array}{l}14.1 \\
24.4 \\
38.5 \\
47.3\end{array}$ & $\begin{array}{r}44.1 \\
76.2 \\
1.20 .0 \\
147.0\end{array}$ & $\begin{array}{l}137.0 \\
237.0 \\
374.0 \\
460.0\end{array}$ \\
\hline 0.3 & $\begin{array}{l}0.05 \\
0.1 \\
0.2\end{array}$ & $\begin{array}{l}1.68 \\
2.93 \\
4.60\end{array}$ & $\begin{array}{r}5.22 \\
9.12 \\
14.4\end{array}$ & $\begin{array}{l}16.3 \\
28.4 \\
44.7\end{array}$ & $\begin{array}{r}50.8 \\
88.6 \\
139.0\end{array}$ & $\begin{array}{l}158.0 \\
276.0 \\
434.0\end{array}$ \\
\hline 0.4 & $\begin{array}{l}0.05 \\
0.1 \\
0.2\end{array}$ & $\begin{array}{l}1.77 \\
3.12 \\
4.89\end{array}$ & $\begin{array}{c}5.52 \\
9.72 \\
15.3\end{array}$ & $\begin{array}{l}17.2 \\
30.3 \\
47.5\end{array}$ & $\begin{array}{r}53.6 \\
94.4 \\
148.0\end{array}$ & $\begin{array}{l}167.0 \\
294.0 \\
462.0\end{array}$ \\
\hline 0.5 & $\begin{array}{l}0.05 \\
0.1\end{array}$ & $\begin{array}{l}1.78 \\
3.17\end{array}$ & $\begin{array}{l}5.56 \\
9.87\end{array}$ & $\begin{array}{l}17.3 \\
30.8\end{array}$ & $\begin{array}{l}54.0 \\
95.9\end{array}$ & $\begin{array}{l}168.0 \\
299.0\end{array}$ \\
\hline
\end{tabular}


Table 4. Stress indices $C_{L}$ for longitudinal moment loading

\begin{tabular}{|c|c|c|c|c|c|c|}
\hline \multicolumn{2}{|c|}{ Shape parameter } & \multicolumn{5}{|c|}{ Radius-to-thickness $(\gamma)$ ratio } \\
\hline$\beta_{1}$ & $\beta_{2}$ & 5 & 10 & 20 & 40 & 80 \\
\hline 0.05 & $\begin{array}{l}0.05 \\
0.1 \\
0.2 \\
0.3 \\
0.4 \\
0.5\end{array}$ & $\begin{array}{l}0.086 \\
0.197 \\
0.385 \\
0.514 \\
0.593 \\
0.634\end{array}$ & $\begin{array}{l}0.286 \\
0.658 \\
1.29 \\
1.72 \\
1.98 \\
2.12\end{array}$ & $\begin{array}{l}0.955 \\
2.20 \\
4.30 \\
5.73 \\
6.61 \\
7.07\end{array}$ & $\begin{array}{l}3.19 \\
7.34 \\
14.4 \\
19.1 \\
22.1 \\
23.6\end{array}$ & $\begin{array}{l}10.7 \\
24.5 \\
47.9 \\
64.0 \\
73.8 \\
78.9\end{array}$ \\
\hline 0.1 & $\begin{array}{l}0.05 \\
0.1 \\
0.2 \\
0.3 \\
0.4\end{array}$ & $\begin{array}{l}0.119 \\
0.290 \\
0.605 \\
0.846 \\
1.01\end{array}$ & $\begin{array}{l}0.399 \\
0.970 \\
2.02 \\
2.82 \\
3.39\end{array}$ & $\begin{array}{c}1.33 \\
3.24 \\
6.75 \\
9.44 \\
11.3\end{array}$ & $\begin{array}{l}4.45 \\
10.8 \\
22.6 \\
31.5 \\
37.8\end{array}$ & $\begin{array}{r}14.9 \\
36.2 \\
75.4 \\
105.0 \\
126.0\end{array}$ \\
\hline 0.2 & $\begin{array}{l}0.05 \\
0.1 \\
0.2 \\
0.3\end{array}$ & $\begin{array}{l}0.144 \\
0.368 \\
0.811 \\
1.18\end{array}$ & $\begin{array}{l}0.480 \\
1.23 \\
2.71 \\
3.93\end{array}$ & $\begin{array}{l}1.60 \\
4.11 \\
9.05 \\
13.1\end{array}$ & $\begin{array}{l}5.36 \\
13.7 \\
30.2 \\
43.8\end{array}$ & $\begin{array}{r}17.9 \\
45.8 \\
101.0 \\
146.0\end{array}$ \\
\hline 0.3 & $\begin{array}{l}0.05 \\
0.1 \\
0.2\end{array}$ & $\begin{array}{l}0.147 \\
0.388 \\
0.880\end{array}$ & $\begin{array}{l}0.491 \\
1.30 \\
2.94\end{array}$ & $\begin{array}{l}1.64 \\
4.33 \\
9.82\end{array}$ & $\begin{array}{l}5.48 \\
14.5 \\
32.8\end{array}$ & $\begin{array}{r}18.3 \\
48.3 \\
110.0\end{array}$ \\
\hline 0.4 & $\begin{array}{l}0.05 \\
0.1 \\
0.2\end{array}$ & $\begin{array}{l}0.142 \\
0.383 \\
0.888\end{array}$ & $\begin{array}{l}0.475 \\
1.28 \\
2.97\end{array}$ & $\begin{array}{l}1.59 \\
4.28 \\
9.91\end{array}$ & $\begin{array}{l}5.30 \\
14.3 \\
33.1\end{array}$ & $\begin{array}{r}17.7 \\
47.7 \\
111.0\end{array}$ \\
\hline 0.5 & $\begin{array}{l}0.05 \\
0.10\end{array}$ & $\begin{array}{l}0.134 \\
0.368\end{array}$ & $\begin{array}{l}0.447 \\
1.23\end{array}$ & $\begin{array}{l}1.49 \\
4.11\end{array}$ & $\begin{array}{c}4.99 \\
13.7\end{array}$ & $\begin{array}{l}16.7 \\
45.8\end{array}$ \\
\hline
\end{tabular}

bending stress in the lug at the pipe surface. It may be noted in these tables that there are several combinations of $\beta_{1}, \beta_{2}$, and $\gamma$ for which $C_{T}, C_{L}$, and $C_{C}$ are less than unity. For these dimensional parameters, the maximum stress is less than the nominal stress in the lug at the lugpipe interface. Since the analysis procedure is intended to cover this interface as well as the pipe, a lower limit of 1.0 must be imposed on the values of the $C_{T}, C_{L}$, and $C_{C}$ indices. These indices are used in 
Table 5. Stress indices $\mathrm{C}_{\mathrm{C}}$ for circumferential moment loading

\begin{tabular}{|c|c|c|c|c|c|c|}
\hline \multicolumn{2}{|c|}{ Shape parameter } & \multicolumn{5}{|c|}{ Radius-to-thickness $(\gamma)$ ratio } \\
\hline$\beta_{1}$ & $\beta_{2}$ & 5 & 10 & 20 & 40 & 80 \\
\hline 0.05 & $\begin{array}{l}0.05 \\
0.1 \\
0.2 \\
0.3 \\
0.4 \\
0.5\end{array}$ & $\begin{array}{l}0.066 \\
0.104 \\
0.148 \\
0.172 \\
0.184 \\
0.190\end{array}$ & $\begin{array}{l}0.246 \\
0.388 \\
0.553 \\
0.640 \\
0.688 \\
0.711\end{array}$ & $\begin{array}{l}0.918 \\
1.45 \\
2.06 \\
2.39 \\
2.57 \\
2.65\end{array}$ & $\begin{array}{l}3.43 \\
5.41 \\
7.70 \\
8.92 \\
9.58 \\
9.90\end{array}$ & $\begin{array}{l}12.8 \\
20.2 \\
28.7 \\
33.3 \\
35.7 \\
37.0\end{array}$ \\
\hline ن.IU & $\begin{array}{l}0.05 \\
0.1 \\
0.2 \\
0.3 \\
0.4\end{array}$ & $\begin{array}{l}0.184 \\
0.303 \\
0.450 \\
0.536 \\
0.587\end{array}$ & $\begin{array}{l}0.685 \\
1.13 \\
1.68 \\
2.00 \\
2.19\end{array}$ & $\begin{array}{l}2.56 \\
4.22 \\
6.27 \\
7.46 \\
8.18\end{array}$ & $\begin{array}{l}9.55 \\
15.7 \\
23.4 \\
27.8 \\
30.5\end{array}$ & $\begin{array}{r}35.6 \\
58.7 \\
87.4 \\
104.0 \\
114.0\end{array}$ \\
\hline 0.2 & $\begin{array}{l}0.05 \\
0.1 \\
0.2 \\
0.3\end{array}$ & $\begin{array}{l}0.459 \\
0.798 \\
1.24 \\
1.52\end{array}$ & $\begin{array}{l}1.71 \\
2.98 \\
4.64 \\
5.67\end{array}$ & $\begin{array}{l}6.40 \\
11.1 \\
17.3 \\
21.2\end{array}$ & $\begin{array}{l}23.9 \\
41.5 \\
64.7 \\
79.0\end{array}$ & $\begin{array}{r}89.1 \\
155.0 \\
241.0 \\
295.0\end{array}$ \\
\hline 0.3 & $\begin{array}{l}0.05 \\
0.1 \\
0.2\end{array}$ & $\begin{array}{l}0.735 \\
1.32 \\
2.13\end{array}$ & $\begin{array}{l}2.74 \\
4.94 \\
7.95\end{array}$ & $\begin{array}{l}10.2 \\
18.4 \\
29.7\end{array}$ & $\begin{array}{r}38.2 \\
68.8 \\
111.0\end{array}$ & $\begin{array}{l}143.0 \\
257.0 \\
113.0\end{array}$ \\
\hline 0.4 & $\begin{array}{l}0.05 \\
0.1 \\
0.2\end{array}$ & $\begin{array}{l}0.986 \\
1.83 \\
3.02\end{array}$ & $\begin{array}{c}3.68 \\
6.84 \\
11.3\end{array}$ & $\begin{array}{l}13.7 \\
25.5 \\
42.1\end{array}$ & $\begin{array}{r}51.3 \\
95.3 \\
157.0\end{array}$ & $\begin{array}{l}191.0 \\
356.0 \\
586.0\end{array}$ \\
\hline 0.5 & $\begin{array}{l}0.0 .5 \\
0.1\end{array}$ & $\begin{array}{l}1.21 \\
2.30\end{array}$ & $\begin{array}{l}4.50 \\
8.59\end{array}$ & $\begin{array}{l}16.8 \\
32.1\end{array}$ & $\begin{array}{r}62.7 \\
120.0\end{array}$ & $\begin{array}{l}34.0 \\
447.0\end{array}$ \\
\hline
\end{tabular}

Section 6 for developing the additaments $\left(S_{n}\right)_{\text {lug }}$ for primary-plus-secondary stresses and $\left(S_{p}\right)_{\text {lug }}$ for peak stresses.

The paramelric study which formed the basis for developing Eqs. (1a), $(1 b)$, and (lc) included only the values of $\beta_{1}$ and $\beta_{2}$ listed in Tables 3 to 5 ; thus the equations should not be used for $\beta_{1}$ or $\beta_{2}$ values higher than 0.5. In addition, the equations should not be used for $\beta_{1} \beta_{2}$ greater than 0.075 . These limitations permit a small extrapolation beyond the 
$\beta_{1} \beta_{2}$ products included in the study but prevent large extrapolations. While the study included parameter values for $\gamma$ up to 80 , the general limitation on stress indices of $D_{0} / t=100$ is recommended for the indices for lugs. These limitations are included in Appendix A, Recommended Addition to ASME Code Section III to Cover Straight Pipe with Integral Structural Attachments.

Ratios of the maximum calculated membrane stress to the maximum calculated secondary stress intensity are given in Tables 6 to 8 for radial thrust, longitudinal moment, and circumferential moment loadings respectively. For all three cases the tabulated values show that the membrane stresses are small with respect to the bending stresses. This fact is used in Section 6 as a part of the basis for establishing the $\mathrm{B}_{\ell}$ indices used in the new term $\left(P_{L}+P_{b}\right)$ lug for primary stresses. The directions and locations of the maximum stresses are included in Appendix $B$ for reference.

\section{Comparisons with ASME Boiler Code, Section I, Paragraph PW-43}

Paragraph $\mathrm{PW}-43$ in Section I of the ASME Boiler Code ${ }^{3}$ gives a design method for loading on structural attachments which considers only radial thrust and longitudinal moment loadings; circumferential moment loadings are not considered. According to this code, the design is acceptable if the following inequality is satisfied:

$$
\frac{W}{2 L_{2}}+\frac{6 M_{L}}{4 L_{2}^{2}} \leq Y,
$$

where $Y$ is the maximum allowable load per unit length of the loaded area ( $1 \mathrm{~b} /$ in.), $W$ is the radial thrust load ( $1 \mathrm{~b}), \mathrm{M}_{\mathrm{L}}$ is the longitudinal moment load (in.-lb), and $\mathrm{L}_{2}$ is one-half the length of the loaded area (in.). The maximum load $Y$ is given graphically in Fig. PW-43.1 of Ref. 3 (the load being identified there as $P$ ). The value of $Y$ depends on whether the direction of loading is tensile or compressive and also on the outside diameter of the pipe for tensile loads. For arbitrary loading directions 
Table 6. Ratios of maximum membrane stress to maximum secondary stress intensity ${ }^{a}$ for thrust loading

\begin{tabular}{|c|c|c|c|c|c|c|}
\hline \multicolumn{2}{|c|}{ Shape parameter } & \multicolumn{5}{|c|}{ Radius-to-thickness $(\gamma)$ ratio } \\
\hline $\bar{B}_{1}$ & $\bar{B}_{2}$ & 5 & 10 & 20 & 40 & 80 \\
\hline \multirow[t]{6}{*}{0.05} & 0.05 & 0.081 & 0.098 & 0.180 & 0.145 & 0.160 \\
\hline & 0.1 & 0.093 & 0.112 & 0.131 & 0.148 & 0.187 \\
\hline & 0.2 & 0.109 & 0.122 & 0.131 & 0.170 & 0.210 \\
\hline & 0.3 & 0.118 & 0.122 & 0.144 & 0.185 & 0.224 \\
\hline & $0 . \overline{4}$ & 0.121 & 0.116 & 0.155 & 0.196 & 0.235 \\
\hline & 0.5 & 0.123 & 0.117 & 0.165 & 0.207 & 0.248 \\
\hline \multirow[t]{5}{*}{0.1} & 0.05 & 0.103 & 0.122 & 0.144 & 0.164 & 0.202 \\
\hline & 0.1 & 0.116 & 0.136 & 0.156 & 0.169 & 0.208 \\
\hline & 0.2 & 0.135 & 0.149 & 0.156 & 0.190 & 0.222 \\
\hline & 0.3 & 0.145 & 0.149 & 0.169 & 0.210 & 0.244 \\
\hline & 0.4 & 0.151 & 0.143 & 0.182 & 0.227 & 0.264 \\
\hline \multirow[t]{4}{*}{0.2} & 0.05 & 0.139 & 0.164 & 0.187 & 0.203 & 0.229 \\
\hline & 0.1 & 0.150 & 0.167 & 0.178 & 0.208 & 0.244 \\
\hline & 0.2 & 0.176 & 0.186 & 0.183 & 0.219 & 0.255 \\
\hline & 0.3 & 0.192 & 0.190 & 0.181 & 0.226 & 0.265 \\
\hline \multirow[t]{3}{*}{0.3} & 0.05 & 0.177 & 0.203 & 0.225 & 0.232 & 0.229 \\
\hline & 0.1 & 0.187 & 0.202 & 0.204 & 0.228 & 0.250 \\
\hline & $0 . ?$ & 0.209 & 0.210 & 0.210 & 0.25 .5 & م. \\
\hline \multirow[t]{2}{*}{0.4} & 0.05 & 0.217 & 0.242 & 0.257 & 0.252 & 0.223 \\
\hline & 0.1 & 0.227 & 0.241 & 0.235 & 0.233 & 0.242 \\
\hline 0.5 & 0.05 & 0.261 & 0.284 & 0.290 & 0.270 & 0.203 \\
\hline
\end{tabular}


Table 7. Ratios of maximum membrane stress to maximum secondary stress intensity for longitudinal moment loading

\begin{tabular}{|c|c|c|c|c|c|c|}
\hline \multicolumn{2}{|c|}{ Shape parameter } & \multicolumn{5}{|c|}{ Radius-to-thickness $(\gamma)$ ratio } \\
\hline$\beta_{1}$ & $\dot{B}_{2}$ & 5 & 10 & 20 & 40 & 80 \\
\hline 0.05 & $\begin{array}{l}0.05 \\
0.1 \\
0.2 \\
0.3 \\
0.4 \\
0.5\end{array}$ & $\begin{array}{l}0.022+^{b} \\
0.038+ \\
0.075 \\
0.112 \\
0.145 \\
0.171\end{array}$ & $\begin{array}{l}0.038+ \\
0.064 \\
0.115 \\
0.149 \\
0.166 \\
0.174\end{array}$ & $\begin{array}{l}0.063 \\
0.103 \\
0.157 \\
0.188 \\
0.209 \\
0.219\end{array}$ & $\begin{array}{l}0.105 \\
0.157 \\
0.192 \\
0.198 \\
0.202 \\
0.199\end{array}$ & $\begin{array}{l}0.166 \\
0.214 \\
0.191 \\
0.179 \\
0.159 \\
0.194\end{array}$ \\
\hline 0.1 & $\begin{array}{l}0.05 \\
0.1 \\
0.2 \\
0.3 \\
0.4\end{array}$ & $\begin{array}{l}0.031+ \\
0.052+ \\
0.094 \\
0.136 \\
0.168\end{array}$ & $\begin{array}{l}0.053+ \\
0.086 \\
0.144 \\
0.180 \\
0.193\end{array}$ & $\begin{array}{l}0.087 \\
0.136 \\
0.193 \\
0.215 \\
0.230\end{array}$ & $\begin{array}{l}0.140 \\
0.202 \\
0.219 \\
0.218 \\
0.217\end{array}$ & $\begin{array}{l}0.215 \\
0.269 \\
0.216 \\
0.186 \\
0.168\end{array}$ \\
\hline 0.2 & $\begin{array}{l}0.05 \\
0.1 \\
0.2 \\
0.3\end{array}$ & $\begin{array}{l}0.050+ \\
0.080+ \\
0.137 \\
0.191\end{array}$ & $\begin{array}{l}0.085+ \\
0.128 \\
0.204 \\
0.249\end{array}$ & $\begin{array}{l}0.131 \\
0.195 \\
0.270 \\
0.272\end{array}$ & $\begin{array}{l}0.195 \\
0.272 \\
0.295 \\
0.239\end{array}$ & $\begin{array}{l}0.271 \\
0.339 \\
0.274 \\
0.180\end{array}$ \\
\hline 0.3 & $\begin{array}{l}0.05 \\
0.1 \\
0.2\end{array}$ & $\begin{array}{l}0.069+ \\
0.110+ \\
0.182\end{array}$ & $\begin{array}{l}0.114+ \\
0.168 \\
0.263\end{array}$ & $\begin{array}{l}0.169 \\
0.244 \\
0.338\end{array}$ & $\begin{array}{l}0.233 \\
0.322 \\
0.353\end{array}$ & $\begin{array}{l}0.298 \\
0.369 \\
0.304\end{array}$ \\
\hline 0.4 & $\begin{array}{l}0.05 \\
0.1\end{array}$ & $\begin{array}{l}0.089+ \\
0.139+\end{array}$ & $\begin{array}{l}0.143 \\
0.350\end{array}$ & $\begin{array}{l}0.203 \\
0.287\end{array}$ & $\begin{array}{l}0.264 \\
0.360\end{array}$ & 0.386 \\
\hline 0.5 & 0.05 & $0.109+$ & 0.172 & 0.234 & 0.291 & \\
\hline
\end{tabular}

Maximum secondary stress intensity for a nominal longitudinal moment, $1 \mathrm{nad}$ of $\mathrm{M}_{\mathrm{L}} / \underline{\mathrm{Z}}_{\ell L}=1.0$ is the same as the stress index $C_{L}=C_{L}^{*}\left[4 \beta_{1} \beta_{2}^{2} \gamma /(3 \pi)\right]$, as defined by Eq. (4b).

$\mathrm{b}_{\text {The }}+"$ sign indicates that the maximum value may actually be larger, since the numerical parameter study did not extend far enough to locate the true maximum. 
Table 8. Ratios of maximum membrane stress to maximum secondary stress intensity ${ }^{a}$ for circumferential moment loading

\begin{tabular}{|c|c|c|c|c|c|c|}
\hline \multicolumn{2}{|c|}{ Shape parameter } & \multicolumn{5}{|c|}{ Radius-to-thickness $(\gamma)$ ratio } \\
\hline$\beta_{1}$ & $B_{2}$ & 5 & 10 & 20 & 40 & 80 \\
\hline \multirow[t]{6}{*}{0.05} & 0.05 & $0.010+b$ & ก. ก17t & $0.028+$ & 0.0121 & 0.063 \\
\hline & 0.1 & $0.013+$ & 0.0211 & $0.034+$ & $0.051+$ & 0.071 \\
\hline & 0.2 & $0.016+$ & $0.026+$ & $0.040+$ & $0.058+$ & $0.079+$ \\
\hline & 0.3 & $0.018+$ & 0.0281 & $0.04 \varepsilon+$ & $0.059+$ & U. U', 16 \\
\hline & 0.4 & $0.020+$ & $0.029+$ & $0.042+$ & $0.057+$ & $0.073+$ \\
\hline & 0.5 & $0.021+$ & $0.030+$ & $0.042+$ & $0.055+$ & $0.069+$ \\
\hline \multirow[t]{5}{*}{0.1} & 0.05 & $0.017+$ & $0.027+$ & $0.041+$ & 0.060 & 0.085 \\
\hline & 0.1 & $0.020+$ & $0.032+$ & $0.049+$ & 0.069 & 0.097 \\
\hline & 0.2 & $0.025+$ & $0.039+$ & $0.059+$ & 0.080 & 0.100 \\
\hline & 0.3 & $0.029+$ & $0.043+$ & $0.062+$ & $0.083+$ & 0.101 \\
\hline & 0.4 & $0.031+$ & $0.045+$ & $0.063+$ & $0.082+$ & $0.100+$ \\
\hline \multirow[t]{4}{*}{0.2} & 0.05 & $0.034+$ & 0.046 & 0.064 & 0.087 & 0.108 \\
\hline & 0.1 & $0.039+$ & 0.053 & 0.072 & 0.095 & 0.118 \\
\hline & 0.2 & $0.048+$ & 0.065 & 0.086 & 0.107 & 0.126 \\
\hline & 0.3 & $0.056+$ & $0.076+$ & 0.095 & 0.113 & 0.128 \\
\hline \multirow[t]{3}{*}{0.3} & 0.05 & 0.048 & 0.064 & 0.085 & 0.102 & 0.113 \\
\hline & 0.1 & 0.053 & 0.070 & 0.092 & 0.110 & 0.115 \\
\hline & 0.2 & 0.064 & 0.084 & 0.106 & 0.125 & 0.129 \\
\hline \multirow[t]{2}{*}{0.4} & 0.05 & 0.063 & 0.083 & 0.101 & 0.114 & 0.111 \\
\hline & 0.1 & 0.068 & 0.087 & 0.107 & 0.113 & $0 . \overline{112}$ \\
\hline 0.5 & 0.05 & 0.080 & 0.100 & 0.118 & 0.122 & 0.108 \\
\hline
\end{tabular}

Maximum secondary stress intensity for a nominal circumfererillal moment load of $\mathrm{M}_{\mathrm{C}} / \mathrm{z}_{\ell C}=1.0$ is the same as the stress index $C_{C}=C_{C}^{*}\left[4 \beta_{1}{ }^{2} \beta_{2} \gamma /(3 \pi)\right]$, as defined by Eq. (4c).

$b_{\text {The }}+"$ sign indicates that the maximum value may actually be larger, since the numerical parameter study did not extend far enough to locate the true maximum. 
and all pipe diameters, an approximate value for $\mathrm{Y}$ is given by

$$
Y=30,000 \frac{t^{2}}{D}
$$

where $t$ is the pipe wall thickness and $D$ is the outside diameter. Substituting Eq. (6) into Eq. (5), the maximum allowable loads must satisfy the following:

$$
\frac{W}{2 L_{2}}+\frac{6 M_{L}}{4 L_{2}^{2}}=30,000 \frac{t^{2}}{D}
$$

The basis for the design method is not known to the authors. However, in discussing the background of PW-43, Melworm and Berman ${ }^{5}$ state
"It was assumed that the tube material behaved elasti- cally. Circumferential tube stress determinations were made for pressure and external load. Thick wall (Lame) theory was used to determine the pressure stresses and thin-ring combined with curved beam theory were used to obtain the stresses caused by external load. The maxi- mum circumferential tube stress was limited to an em- pirical value of 20,000 psi."

Apparently the 20,000-psi limit was placed on the sum of the circumferential stresses in the pipe due to both internal pressure and external loads. If that were so, and assuming that the circumferential stress due to pressure was equal to a typical value of $15,000 \mathrm{psi}$, the allowable stress which would be available for the external loads would be 5000 psi. We can thus write an equation for the maximum allowable stress in the pipe due to $W$ and $M_{L}$ in terms of the lug dimensions and unknown dimensionless coefficients $\mathrm{C}_{\mathrm{T}}^{\prime}$ and $\mathrm{C}_{\mathrm{L}}^{\prime}$ :

$$
\mathrm{C}_{\mathrm{T}}^{\prime} \frac{\mathrm{W}}{\mathrm{A}_{\ell}}+\mathrm{C}_{\mathrm{L}}^{\prime} \frac{\mathrm{M}_{\mathrm{L}}}{\mathrm{Z}_{\ell \mathrm{C}}}=5000 \mathrm{psi} \text {, }
$$

where the cross-sectional area of the lug $A_{l}=4 L_{1} I_{2}$ and the section modulus $Z_{\ell C}=(4 / 3) I_{1} L_{2}{ }^{2}$. Simply rearranging the terms in Eq. (7) gives

$$
\frac{2 L_{1}}{6 t} \frac{D}{t} \cdot\left[\frac{W}{4 L_{1} L_{2}}+\frac{M_{L}}{(4 / 3) L_{1} L_{2}^{2}}\right]=5000 \mathrm{psi}
$$


From Eqs. (8) and (9),

$$
C_{T}^{\prime}=C_{L}^{\prime}=L_{I} D / 3 t^{2}
$$

or, in terms of nondimensional parameters $\beta_{1}=L_{1} / r$ and $\gamma=r / t$,

$$
\mathrm{C}_{\mathrm{T}}^{\prime}=\mathrm{C}_{\mathrm{L}}^{\prime}=(2 / 3) \mathrm{B}_{1} \gamma^{2}
$$

It is thus apparent that the PW-4.3 analysis method implies equal stress indices $C_{T}^{\prime}$ and $C_{L}^{\prime}$ for hoth thrust. and moment loadings, although the width of the lug $\left(2 \mathrm{~L}_{1}\right)$ does not enter into the PW-43 criteria [Eq. (5)]. Typically the lug width would be about 0.2 times the pipe diameter, in which case $\beta_{1}=0.1$. Using this value for $\beta_{1}$, a direct comparison can be made between the PW-43 design method and the stress indices $C_{T}$ and $C_{I}$ developed in this report.

Table 9 gives some comparisons of $(2 / 3) B_{1} \gamma^{2}$ with $C_{T}$ and $C_{L}$. As judged by the stress index, the $\mathrm{PW}-43$ method tends to be unconservative for thrust "load (except for $\gamma=40$ ) and conservative for moment load.

Table 9. Comparison of PW-43 method with $C$ indices

\begin{tabular}{|c|c|c|c|c|c|c|}
\hline \multirow{2}{*}{$B_{1}$} & \multirow{2}{*}{$B_{\varepsilon}$} & \multirow{2}{*}{$\begin{array}{l}\text { Index } \\
\text { source }\end{array}$} & \multicolumn{3}{|c|}{ Radius-to-thickness $(\gamma)$} & ratio \\
\hline & & & 5 & 10 & 20 & 40 \\
\hline 0.1 & Any & $P W-43^{a}$ & 1.67 & 6.67 & 26.7 & 107.0 \\
\hline \multirow[t]{2}{*}{0.1} & 0.2 & $\mathrm{C}_{\mathrm{II}}$ & 2.74 & 0.53 & 26.6 & $8 \overline{2} \cdot y$ \\
\hline & & $\mathrm{C}_{\mathrm{L}}$ & 0.60 & 2.02 & 6.75 & 22.6 \\
\hline \multirow[t]{2}{*}{0.1} & 0.3 & $\mathrm{C}_{\mathrm{T}}$ & 3.38 & 10.5 & 32.8 & 102.0 \\
\hline & & $\mathrm{C}_{\mathrm{L}}$ & 0.8 .5 & 2.82 & 9.44. & 31.5 \\
\hline \multirow[t]{2}{*}{0.1} & 0.4 & $\mathrm{C}_{\mathrm{T}}$ & 3.80 & 11.8 & 36.9 & 115.0 \\
\hline & & $\mathrm{C}_{\mathrm{L}}$ & 1.01 & 3.39 & 11.3 & 37.8 \\
\hline
\end{tabular}
for thrust and longitudinal moment loading

$a_{\text {Index }}=(2 / 3) \beta_{1} \gamma^{2}$ for both thrust and longitudinal moment. 
In general, however, the PW-43 method gives permissible loadings in the same range as the stress-index method when the latter method is used with $\left(s_{n}\right)_{\text {lug }}=5000 \mathrm{psi}$. The reason for the conservatism with respect to moment load is that $\mathrm{PW}-43$ treats the maximum nominal stress due to a moment as equivalent to a thrust load acting along the entire length of the lug; that is, $6 \mathrm{M} / 2 \mathrm{I}_{2}=\mathrm{W}$.

\section{Comparisons with Welding Research} Council Bulletin 107

Welding Research Council Bulletin 107, Local Stresses in Spherical and Cylindrical Shells Due to External Loadings, ${ }^{4}$ is a widely used design guide based on theoretical and numerical results developed by Bijlaard ${ }^{6,7}$ for distributed loads on cylindrical shells as shown in Fig. 2. WRC Bulletin 107 also includes empirical corrections to Bijlaard's results that were based principally on results from tests of two models of cylindrical shells with nozzles. For lack of a more directly applicable analysis, Bijlaard's results have been used to estimate stresses due to thrust or moment loads applied to a nozzle in a cylindrical shell and to loads applied through a lug or other relatively rigid attachment.

The data given in WRC Bulletin 107 for thrust load are based on calculations for cylinders with length-to-radius ratios $\mathrm{L} / \mathrm{r}=8$. The value of $\mathrm{L} / \mathrm{r}$ used for moment loadings is not clearly stated; however, the etresses are only slightly dependent upon this ratio. The stresses for thrust load were calculated for the center of the loaded area, while those for moment loads are for the edge of the loaded area.

Dodge $^{2}$ calculated stresses based on Bijlaard's theory with the following refinements: (1) certain terms in the solution were retained in the numerical analysis as recommended by Weil, Laupa, and Murphy in their discussion at the end of Ref. 6; (2) the angularity of the surface loads was taken into consideration; and (3) the stresses due to "beam bending" were subtracted out. For sufficiently large values of $\mathrm{L} / \mathrm{r}$, the stresses become independent of $\mathrm{L} / \mathrm{r}$. (In using the stress-index method, as given in Section 6, the stresses due to beam bending are included in the existing Code equations.) 
ORNL- OWG 72- 12146R
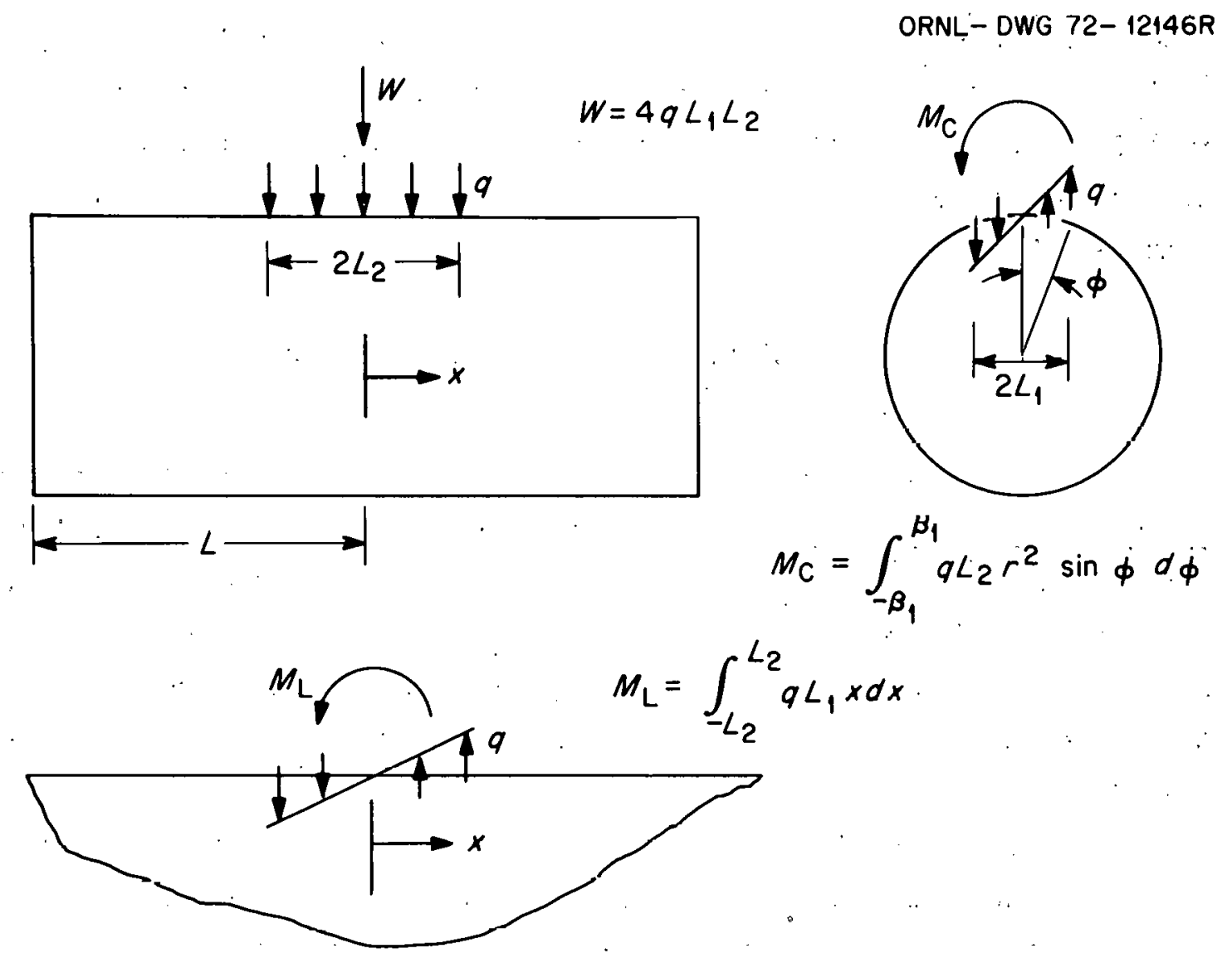

BIJLAAARD THËORY

LOADS ARE EQUILIBRATED BY DISTRIBUTED SHEARS AT END OF CYLINDER,$x= \pm L$

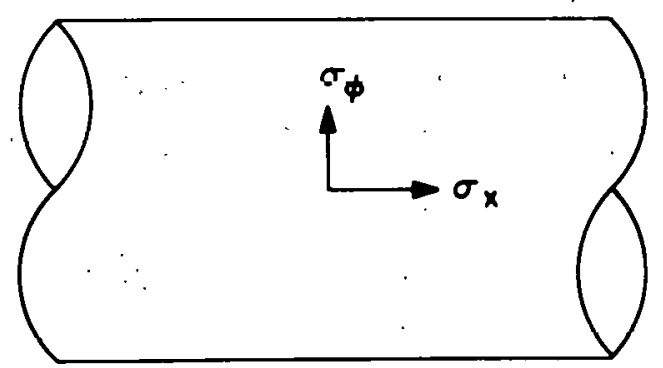

Fig. 2. Illustration of Bijlaard's distributed-load equivalence with thrust and moment loads. 
The stress indices $C_{T}, C_{L}$, and $C_{C}$ are based on calculated stresses at the edge of or outside* the loaded area. The major difference between Bulletin 107 and the stress indices is for thrust loading; Bulletin 107 gives stresses at the center of the loaded area, whereas the stress indices are based on stresses at the edge of the loaded area. Detailed comparisons for each of the three loadings are discussed below.

Thrust loading

Table 10 shows comparisons for thrust loadings on square loaded areas. Dodge** gives maximum stresses at the edge of the loaded area, whereas Bulletin 107 is based on stresses at the center of the loaded area. Stresses calculated using WRC 107 are higher than these reported in Ref. 2 , and a check of the detailed calculations indicates the discrepancy is almost entirely due to the difference between the stresses at the center of the loaded area and those at the edge of the loaded area. Indices obtained by the approximate formula, Eq. (4a), however, are higher than or of the same order as the maximum stress obtained by Bulletin 107. This is primarily due to the conservatism introduced in developing approximate formulas with the required simplicity; for more details see Ref. 2.

Table 11 shows comparisons for thmust loadings on rectangular loaded areas for $\beta_{1} / \beta_{2}$ ratios of $1 / 4,1 / 2,2$, and 4 . The equations included in WRC 107 are approximations developed by Bijlaard ${ }^{7}$ based on a relatively few calculated results for these ratios. To avoid additional interpolations or extrapolations here, the same ratios were used in making the comparisons. The WRC 107 equations give, in effect, an "equivalent" square area. As shown in the table, the approximate equations of Bulletin 107 appear to be adequate, since, with only a few minor exceptions, the stresses obtained with these equations are not less than the more accurate results obtained by Dodge. For thrust loads on rectangular areas,

\footnotetext{
*For most parameters included in the study, the maximum surface stresses were at the edge of the loaded area. See Appendix B.

**Reference to Dodge in these comparisons is meant to indicate the detailed stresses presented in Ref. 2 and used as the basis for developing the approximate formulas, Eqs: (4a), (4b), and (4c).
} 

Table 10. Camparisons for thrust loadings
on square loaded areas

\begin{tabular}{|c|c|c|c|c|c|c|c|}
\hline$B_{1}$ & $B_{2}$ & $\gamma$ & Method & $\sigma_{\varnothing 0} / s_{\ell}$ & $\sigma_{\phi i} / s_{\ell}$ & $\sigma_{x o} / s_{\ell}$ & $\sigma_{x i} / s_{\ell}$ \\
\hline \multirow[t]{5}{*}{0.05} & 0.05 & 5 & $\begin{array}{l}\text { WRC } 107 \\
\text { Dodge } \\
\text { Eq. (4a) }\end{array}$ & $\begin{array}{r}-0.49 \\
-0.42 \\
0.66\end{array}$ & $\begin{array}{l}0.39 \\
0.32\end{array}$ & $\begin{array}{l}-0.44 \\
-0.33\end{array}$ & $\begin{array}{l}0.34 \\
0.28\end{array}$ \\
\hline & & 10. & $\begin{array}{l}\text { WRC } 107 \\
\text { Dodge } \\
\text { Eq. (4a) }\end{array}$ & $\begin{array}{r}-1.71 \\
-1.54 \\
2.05\end{array}$ & $\begin{array}{l}1.35 \\
1.15\end{array}$ & $\begin{array}{l}-1.52 \\
-1.13\end{array}$ & $\begin{array}{l}1.12 \\
0.87\end{array}$ \\
\hline & . & 20 & $\begin{array}{l}\text { WRC } 107 \\
\text { Iodge } \\
\text { E'q. (40) }\end{array}$ & $\begin{array}{r}-6.08 \\
-3.39 \\
6.39\end{array}$ & $\begin{array}{l}4.48 \\
3.46\end{array}$ & $\begin{array}{l}-5.10 \\
-3.83\end{array}$ & $\begin{array}{r}3.54 \\
2.64\end{array}$ \\
\hline & & 40 & $\begin{array}{l}\text { WRC } 107 \\
\text { Dodge } \\
\text { Eq. (4a) }\end{array}$ & $\begin{array}{c}-21.44 \\
-18.46 \\
19.9\end{array}$ & $\begin{array}{l}15.04 \\
13.3 \%\end{array}$ & $\begin{array}{l}-16.80 \\
-12.511\end{array}$ & $\begin{array}{r}11.04 \\
1.34\end{array}$ \\
\hline & & 80 & $\begin{array}{l}\text { WRC } 107 \\
\text { Dodge } \\
\text { Eq. (48) }\end{array}$ & $\begin{array}{c}-73.44 \\
-60.95 \\
62.1\end{array}$ & $\begin{array}{l}49.44 \\
43.93\end{array}$ & $\begin{array}{l}-57.68 \\
-39.38\end{array}$ & $\begin{array}{l}34.48 \\
18.47\end{array}$ \\
\hline \multirow[t]{5}{*}{0.10} & 0.10 & 5 & $\begin{array}{l}\text { WRC } 107 \\
\text { Dodge } \\
\text { Eq. (48) }\end{array}$ & $\begin{array}{r}-1.51 \\
-1.26 \\
1.74\end{array}$ & $\begin{array}{l}1.11 \\
0.88\end{array}$ & $\begin{array}{l}-1.3 .5 \\
-0.89\end{array}$ & $\begin{array}{l}0.94 \\
0.70\end{array}$ \\
\hline & & 10 & $\begin{array}{l}\text { WRC } 107 \\
\text { Dodge } \\
\text { Eq. (4a) }\end{array}$ & $\begin{array}{r}-5.02 \\
-4.14 \\
5.44\end{array}$ & $\begin{array}{l}3.66 \\
3.11\end{array}$ & $\begin{array}{l}-4.37 \\
-2.93\end{array}$ & $\begin{array}{l}2.82 \\
1.96\end{array}$ \\
\hline & & 20 & $\begin{array}{l}\text { WRC } 107 \\
\text { Dodge } \\
\text { Eq. (48) }\end{array}$ & $\begin{array}{c}-17.87 \\
-14.83 \\
16.9\end{array}$ & $\begin{array}{l}12.27 \\
10.51\end{array}$ & $\begin{array}{r}-14.48 \\
-9.34\end{array}$ & $\begin{array}{l}8.56 \\
4.96\end{array}$ \\
\hline & & 40 & $\begin{array}{l}\text { WRC 10\% } \\
\text { Dodge } \\
\mathrm{Eq}_{\text {q. }}\left(4{ }^{2}\right)\end{array}$ & $\begin{array}{c}-58.88 \\
-47.82 \\
52.8\end{array}$ & $\begin{array}{l}37.12 \\
34.73\end{array}$ & $\begin{array}{l}-45.76 \\
-28.75\end{array}$ & $\begin{array}{l}23.36 \\
10.89\end{array}$ \\
\hline & & 80 & $\begin{array}{l}\text { WRC } 107 \\
\text { Dodge } \\
\text { Eq. (4a) }\end{array}$ & $\begin{array}{r}-179.5 \\
-147.7 \\
165.0\end{array}$ & $\begin{array}{l}115.5 \\
112.5\end{array}$ & $\begin{array}{r}-136.8 \\
-87.45\end{array}$ & $\begin{array}{l}53.63 \\
18.99\end{array}$ \\
\hline \multirow[t]{2}{*}{0.20} & 0.20 & 5 & $\begin{array}{l}\text { WRC } 107 \\
\text { Dodge } \\
\text { Dq. }(4 a)\end{array}$ & $\begin{array}{r}-4.23 \\
-3.27 \\
3.96\end{array}$ & $\begin{array}{l}2.78 \\
2.12\end{array}$ & $\begin{array}{l}-3.59 \\
-2.04\end{array}$ & $\begin{array}{l}2.07 \\
1.38\end{array}$ \\
\hline & & 10 & $\begin{array}{l}\text { WRC } 107 \\
\text { Dodge } \\
\text { Eq. (4a) }\end{array}$ & $\begin{array}{c}-13.15 \\
-10.1 / 4 \\
12.4\end{array}$ & $\begin{array}{l}8.35 \\
1.33\end{array}$ & $\begin{array}{r}-10.83 \\
-6.31\end{array}$ & $\begin{array}{l}5.30 \\
3.08\end{array}$ \\
\hline \multirow[t]{3}{*}{. } & . & 20 & $\begin{array}{l}\text { WRC } 107 \\
\text { Dodge } \\
\text { Eq. (4a) }\end{array}$ & $\begin{array}{c}-41.92 \\
-34.03 \\
38.5\end{array}$ & $\begin{array}{l}27.20 \\
24.99\end{array}$ & $\begin{array}{l}-31.74 \\
-19.53\end{array}$ & $\begin{array}{r}11.26 \\
5.76\end{array}$ \\
\hline & & 40 & $\begin{array}{l}\text { WRC } 107 \\
\text { Dudige } \\
\text { Eq. (4a) }\end{array}$ & $\begin{array}{r}-125.7 \\
-103.4 \\
120.0\end{array}$ & $\begin{array}{l}77.06 \\
01.91\end{array}$ & $\begin{array}{l}-89.60 \\
=60.96\end{array}$ & $\begin{array}{r}17.92 \\
8.23\end{array}$ \\
\hline & & 80 & $\begin{array}{l}\text { WRC } 107 \\
\text { Dodge } \\
\text { Eq. (4a) }\end{array}$ & $\begin{array}{r}-351.5 \\
-306.2 \\
374.0\end{array}$ & $\begin{array}{l}226.0 \\
257.5\end{array}$ & $\begin{array}{l}-254.2 \\
-193.0\end{array}$ & $\begin{array}{r}16.13 \\
2.00\end{array}$ \\
\hline
\end{tabular}

For thrust load (W of Fig. 2), $S=W / 4 L_{1} L_{2}$. Subscripts $\varnothing$ and $x$ refer to the circumferential and axill directions respectively; $i$ is inside surface and $o$ is outside surface. 

Table 11. Comparisons for thrust loadings on
rectangular loaded areas

\begin{tabular}{|c|c|c|c|c|c|c|c|}
\hline$\beta_{1}$ & $\beta_{2}$ & $\gamma$ & Method & $\sigma_{\varnothing_{0}} / \mathrm{s}_{\ell}$ & $\sigma_{\phi_{i}} / s_{l}$ & $\sigma_{x o} / S_{l}$ & $\sigma_{x i} / s_{l}$ \\
\hline \multirow[t]{4}{*}{0.05} & 0.20 & 5 & $\begin{array}{l}\text { WRC } 107 \\
\text { Dodge } \\
\text { Eq. (4a) }\end{array}$ & $\begin{array}{r}-1.58 \\
-1.25 \\
1.72\end{array}$ & $\begin{array}{l}1.20 \\
0.87\end{array}$ & $\begin{array}{l}-1.22 \\
-0.89\end{array}$ & $\begin{array}{l}0.81 \\
0.70\end{array}$ \\
\hline & & 10 & $\begin{array}{l}\text { WRC } 107 \\
\text { Dodge } \\
\text { Eq. (4a) }\end{array}$ & $\begin{array}{r}-5.42 \\
-4.38 \\
5.36\end{array}$ & $\begin{array}{l}3.94 \\
3.07\end{array}$ & $\begin{array}{l}-3.76 \\
-2.91\end{array}$ & $\begin{array}{l}2.24 \\
1.95\end{array}$ \\
\hline & & 20 & $\begin{array}{l}\text { WRC } 107 \\
\text { Dodge } \\
\text { Eq. (4a) }\end{array}$ & $\begin{array}{c}-18.72 \\
-14.74 \\
16.7\end{array}$ & $\begin{array}{l}13.92 \\
10.43\end{array}$ & $\begin{array}{r}-12.00 \\
-9.33\end{array}$ & $\begin{array}{l}6.24 \\
4.99\end{array}$ \\
\hline & & 40 & $\begin{array}{l}\text { WRC } 107 \\
\text { Dodge } \\
\text { Eq. (4a) }\end{array}$ & $\begin{array}{c}-56.00 \\
-47.5 \\
52.1\end{array}$ & $\begin{array}{l}40.0 \\
34.4\end{array}$ & $\begin{array}{l}-32.3 \\
-28.8\end{array}$ & $\begin{array}{l}11.5 \\
11.0\end{array}$ \\
\hline & & 80 & $\begin{array}{l}\text { WRC } 107 \\
\text { Dodge } \\
\text { Eq. (4a) }\end{array}$ & $\begin{array}{r}-189.9 \\
-146.2 \\
162.0\end{array}$ & $\begin{array}{l}141.9 \\
111.3\end{array}$ & $\begin{array}{r}-107.5 \\
-85.9\end{array}$ & $\begin{array}{l}30.7 \\
17.6\end{array}$ \\
\hline \multirow[t]{5}{*}{0.05} & 0.10 & 5 & $\begin{array}{l}\text { WRC } 107 \\
\text { Dodge } \\
\text { Eq. (4a) }\end{array}$ & $\begin{array}{r}-0.89 \\
-0.73 \\
1.11\end{array}$ & $\begin{array}{l}0.69 \\
0.52\end{array}$ & $\begin{array}{l}-0.73 \\
-0.59\end{array}$ & $\begin{array}{l}0.53 \\
0.50\end{array}$ \\
\hline & & 10 & $\begin{array}{l}\text { WRC } 107 \\
\text { Dodge } \\
\text { Eq. (4a) }\end{array}$ & $\begin{array}{r}-3.16 \\
-2.60 \\
3.44\end{array}$ & $\begin{array}{l}2.32 \\
1.83\end{array}$ & $\begin{array}{l}-2.41 \\
-2.04\end{array}$ & $\begin{array}{l}1.64 \\
1.53\end{array}$ \\
\hline & & 20 & $\begin{array}{l}\text { WRC } 107 \\
\text { Dodge } \\
\text { Eq. (4a) }\end{array}$ & $\begin{array}{c}-10.88 \\
-8.97 \\
10.7\end{array}$ & $\begin{array}{l}8.32 \\
6.16\end{array}$ & $\begin{array}{l}-8.24 \\
-6.78\end{array}$ & $\begin{array}{l}5.20 \\
4.41\end{array}$ \\
\hline & & 40 & $\begin{array}{l}\text { WRC } 107 \\
\text { Dodge } \\
\text { Eq. (4a) }\end{array}$ & $\begin{array}{c}-37.12 \\
-29.72 \\
33.5\end{array}$ & $\begin{array}{l}26.24 \\
19.84\end{array}$ & $\begin{array}{l}-22.88 \\
-21.42\end{array}$ & $\begin{array}{l}11.68 \\
11.57\end{array}$ \\
\hline & & 80 & $\begin{array}{l}\text { WRC } 107 \\
\text { Dodge } \\
\text { Eq. (4a) }\end{array}$ & $\begin{array}{c}-114.4 \\
-33.79 \\
104.0\end{array}$ & $\begin{array}{l}77.60 \\
61.37\end{array}$ & $\begin{array}{l}-80.00 \\
-64.78\end{array}$ & $\begin{array}{l}35.20 \\
25.77\end{array}$ \\
\hline 0.20 & 0.10 & 5 & $\begin{array}{l}\text { WRC } 107 \\
\text { Dodge } \\
\text { Eq. (4a) }\end{array}$ & $\begin{array}{r}-2.28 \\
-2.03 \\
2.52\end{array}$ & $\begin{array}{l}1.51 \\
1.29\end{array}$ & $\begin{array}{l}-2.16 \\
-1.55\end{array}$ & $\begin{array}{l}1.39 \\
1.19\end{array}$ \\
\hline
\end{tabular}


Table 11 (continued)

\begin{tabular}{|c|c|c|c|c|c|c|c|}
\hline$B_{1}$ & $\beta_{2}$ & $\gamma$ & Method & $\sigma_{\varnothing 0} / s_{\ell}$ & $\sigma_{\emptyset_{i}} / S_{\ell}$ & $\sigma_{x o} / s_{\ell}$ & $\sigma_{x i} / s_{\ell}$ \\
\hline \multirow[t]{4}{*}{$\cdot$} & & $10^{\circ}$ & $\begin{array}{l}\text { WRC } 107 \\
\text { Dodge } \\
\text { Eq. (4a) }\end{array}$ & $\begin{array}{r}-7.52 \\
-6.90 \\
7.84\end{array}$ & $\begin{array}{l}4.48 \\
4.35\end{array}$ & $\begin{array}{l}-6.61 \\
-4.97\end{array}$ & $\begin{array}{l}3.76 \\
3.14\end{array}$ \\
\hline & . & 20 & $\begin{array}{l}\text { WRC } 107 \\
\text { Dodge } \\
\text { E'a. (la) }\end{array}$ & $\begin{array}{c}-23.84 \\
-21.14 \\
24.4\end{array}$ & $\begin{array}{l}14.56 \\
13.86\end{array}$ & $\begin{array}{l}-21.44 \\
-15.17\end{array}$ & $\begin{array}{r}11.20 \\
7.09\end{array}$ \\
\hline & & 40 & $\begin{array}{l}\text { WRC } 107 \\
\text { Lodge } \\
\text { Eq. (4a) }\end{array}$ & $\begin{array}{c}-75.20 \\
-66.77 \\
76.2\end{array}$ & $\begin{array}{l}40.00 \\
12.39\end{array}$ & $\begin{array}{r}-61.57 \\
-44.00\end{array}$ & $\begin{array}{l}24.45 \\
.2 .25\end{array}$ \\
\hline & & 80 & $\begin{array}{l}\text { WRC } 107 \\
\text { Dodge } \\
\text { Eq. (4a) }\end{array}$ & $\begin{array}{r}-220.2 \\
-188.3 \\
237.0\end{array}$ & $\begin{array}{l}117.8 \\
125.3\end{array}$ & $\begin{array}{l}-170.4 \\
-124.4\end{array}$ & $\begin{array}{r}38.53 \\
9.04\end{array}$ \\
\hline \multirow[t]{2}{*}{0.40} & 0.10 & 5 & $\begin{array}{l}\text { WRC } 107 \\
\text { Dodge } \\
\mathrm{Eq} \cdot(4 a)\end{array}$ & $\begin{array}{r}-2.85 \\
-2.84 \\
3.12\end{array}$ & $\begin{array}{l}1.38 \\
1.42\end{array}$ & $\begin{array}{l}-3.08 \\
-2.36\end{array}$ & $\begin{array}{l}1.72 \\
1.74\end{array}$ \\
\hline & & 10 & $\begin{array}{l}\text { WRC } 107 \\
\text { Dodge } \\
\text { Eu. (4a) }\end{array}$ & $\begin{array}{r}-8.77 \\
-9.07 \\
9.72\end{array}$ & $\begin{array}{l}3.33 \\
4.39\end{array}$ & $\begin{array}{l}-9.02 \\
-7.04\end{array}$ & $\begin{array}{l}4.22 \\
4.03\end{array}$ \\
\hline \multirow[t]{3}{*}{$\theta$} & $=$ & 20 & $\begin{array}{l}\text { WRC } 107 \\
\text { Dodge } \\
\text { Eq. (4a) }\end{array}$ & $\begin{array}{c}-25.28 \\
-26.51 \\
30.3\end{array}$ & $\begin{array}{r}9.28 \\
12.20\end{array}$ & $\begin{array}{l}-24.90 \\
-19.46\end{array}$ & $\begin{array}{l}8.90 \\
7.08\end{array}$ \\
\hline & & 40 & $\begin{array}{l}\text { WRC } 107 \\
\text { Dodge } \\
\text { Eq: (4a) }\end{array}$ & $\begin{array}{r}-71.42 \\
-70.57 \\
94.4\end{array}$ & $\begin{array}{l}17.66 \\
.31 .94\end{array}$ & $\begin{array}{l}-64.00 \\
-49.47\end{array}$ & $\begin{array}{r}12.80 \\
5.53\end{array}$ \\
\hline & & 80 & $\begin{array}{l}\text { WRC } 107 \\
\text { Dodge } \\
\text { L'q. (4a) }\end{array}$ & $\begin{array}{r}-177.4 \\
-172.5 \\
294.0\end{array}$ & $\begin{array}{l}31.49 \\
83.69\end{array}$ & $\begin{array}{l}-165.4 \\
-121.6\end{array}$ & $\begin{array}{r}6.66 \\
-20.11\end{array}$ \\
\hline
\end{tabular}

For thrust loads $\mathrm{S}_{\ell}=\mathrm{W} / 4 \mathrm{~L}_{1} \dot{L}_{2}$; for subscript notation, see footnote $a$ of Table 10 . 
the stress-index equation, Eq. (4a), tends to be more conservative than either the WRC 107 or Dodge results for $\beta_{1} / \beta_{2}$ greater than 1 ; it is also more conservative than Dodge but less conservative than WRC 107 for $\beta_{1} / \beta_{2}$ less than 1 .

\section{Moment loadings}

Tables 12 and 13 show comparisons for longitudinal and circumferential moment loadings, respectively, on square areas. For the range of parameters covered in these comparisons, the WRC 107 results and those obtained by Dodge are essentially the same - within the accuracy with which the graphs in Bulletin 107 can be read and interpolated. This indicates that the modifications made in Ref. 2 do not produce significant changes within this parameter range. The parameters for which large empirical corrections were made in Bulletin 107 are not included. For both types of moment loadings, Eqs. ( $4 b$ ) and (4c) tend to be conservative with respect to the other two calculations. For the case where $\beta_{1}=\beta_{2}=0.2$, for example, Eqs. (4b) and (4c) give results which range from about 1.1 to 1.7 times the results of the other two.

Comparisons for longitudinal and circumferential moment loadings on rectangular areas are shown in Tables 14 and 15 respectively. For longitudinal moment loadings (Table 14), the approximate equations of Bulletin 107 apparently failed to locate the maximum stress and for some parameters tended to underestimate the magnitude. See, for example, the case for $\beta_{1}=0.05, \beta_{2}=0.20$, and $\gamma=80$, where WRC 107 gives a maximum stress of $-25.4 S_{\ell}$ on the outside surface in the axial direction $\left(\sigma_{x o}\right)$, whereas Dodge's calculations (based on Bijlaard's complete equations) gives a maximum stress of $-39.3 \mathrm{~S}_{l}$ on the outside surface in the circumferential direction $\left(\sigma_{\emptyset_{0}}\right)$. On the other hand, the stress-index equation lfor this case, Eq. (4b)] always tends to be conservative with respect to the maximum.

The comparisons for a circumferential moment loading on rectangular areas given in Table 15 show that the approximate equations of WRC 107 give locations and directions for the maximum stresses that generally agree with the more detailed calculations of Dodge. However, for cases 
Table 12. Comparisons for longitudinal moment loadings on square loaded areas ${ }^{a}$

\begin{tabular}{|c|c|c|c|c|c|c|c|}
\hline$\beta_{1}$ & $B_{2}$ & $\gamma$ & Method & $\sigma_{\varnothing 0} / s_{\ell}$ & $\sigma_{\varnothing i} / s_{\ell}$ & $\sigma_{x 0} / s_{\ell}$ & $\sigma_{x i} / s_{\ell}$ \\
\hline \multirow[t]{5}{*}{0.05} & 0.05 & 5 & $\begin{array}{l}\text { WRC } 107 \\
\text { Iodge } \\
\text { Eq. (4b) }\end{array}$ & $\begin{array}{l}-0.04 \\
-0.03\end{array}$ & $\begin{array}{l}0.03 \\
0.03\end{array}$ & $\begin{array}{r}-0.06 \\
-0.05 \\
0.09\end{array}$ & $\begin{array}{l}0.05 \\
0.05\end{array}$ \\
\hline & & 10 & $\begin{array}{l}\text { WRC } 107 \\
\text { Dodge } \\
\text { Eq. (4b) }\end{array}$ & $\begin{array}{l}-0.14 \\
-0.13\end{array}$ & $\begin{array}{l}0.12 \\
0.12\end{array}$ & $\begin{array}{r}-0.21 \\
-0.21 \\
0.29\end{array}$ & $\begin{array}{l}0.21 \\
0.21\end{array}$ \\
\hline & & 20 & $\begin{array}{l}\text { WRC } 107 \\
\text { Dodge } \\
\text { Eq. (4b) }\end{array}$ & $\begin{array}{l}-0.54 \\
-0.52\end{array}$ & $\begin{array}{l}0.45 \\
0.42\end{array}$ & $\begin{array}{r}-0.81 \\
-0.80 \\
0.95\end{array}$ & $\begin{array}{l}0.79 \\
0.78\end{array}$ \\
\hline & n & 40 & $\begin{array}{l}\text { WRC } 107 \\
\text { linnge } \\
\text { Eq. (4b) }\end{array}$ & $\begin{array}{l}-2.16 \\
-2.11\end{array}$ & $\begin{array}{l}1.62 \\
1.31\end{array}$ & $\begin{array}{r}-3.21 \\
-3.115 \\
3.19\end{array}$ & $\begin{array}{l}3.07 \\
2.47\end{array}$ \\
\hline & & 80 & $\begin{array}{l}\text { WRC } 107 \\
\text { Dodge } \\
\text { Eq. (4b) }\end{array}$ & $\begin{array}{l}-8.51 \\
-8.29\end{array}$ & $\begin{array}{l}5.31 \\
4.93\end{array}$ & $\begin{array}{c}-11.95 \\
-11.08 \\
10.7\end{array}$ & $\begin{array}{l}11.09 \\
10.21\end{array}$ \\
\hline \multirow[t]{5}{*}{0.10} & 0.10 & 5 & $\begin{array}{l}\text { WRC } 107 \\
\text { Dodge } \\
\text { Eq. (4b) }\end{array}$ & $\begin{array}{l}-0.14 \\
-0.14\end{array}$ & $\begin{array}{l}0.12 \\
0.12\end{array}$ & $\begin{array}{r}-0.21 \\
-0.21 \\
0.29\end{array}$ & $\begin{array}{l}0.21 \\
0.21\end{array}$ \\
\hline & . & 10 & $\begin{array}{l}\text { WRC } 107 \\
\text { Dodge } \\
\text { Eq. ( } 4 b)\end{array}$ & $\begin{array}{l}-0.55 \\
-0.57\end{array}$ & $\begin{array}{l}0.40 \\
0.42\end{array}$ & $\begin{array}{r}-0.80 \\
-0.81 \\
0.97\end{array}$ & $\begin{array}{l}0.76 \\
0.78\end{array}$ \\
\hline & & 20 & $\begin{array}{l}\text { WRC } 107 \\
\text { Dodge } \\
\text { Fr. (4b) }\end{array}$ & $\begin{array}{l}-2.16 \\
-2.26\end{array}$ & $\begin{array}{l}1.30 \\
1.40\end{array}$ & $\begin{array}{r}-2.93 \\
-2.98 \\
3.34\end{array}$ & $\begin{array}{l}2.71 \\
2.76\end{array}$ \\
\hline & $\therefore$ & 40 & $\begin{array}{l}\text { WRC } 107 \\
\text { Dodge } \\
\text { Eq. (4v) }\end{array}$ & $\begin{array}{l}-7.92 \\
-8.59\end{array}$ & $\begin{array}{l}3.86 \\
4.21\end{array}$ & $\begin{array}{c}-10.06 \\
-10.22 \\
10.8\end{array}$ & $\begin{array}{l}8.89 \\
8.98\end{array}$ \\
\hline & & 80 & $\begin{array}{l}\text { WRC } 107 \\
\text { Dodge } \\
\text { Eq. (4b) }\end{array}$ & $\begin{array}{l}-27.18 \\
-30.13\end{array}$ & $\begin{array}{r}9.69 \\
10.58\end{array}$ & $\begin{array}{c}-29.72 \\
-31.58 \\
36.2\end{array}$ & $\begin{array}{l}23.53 \\
25.25\end{array}$ \\
\hline \multirow[t]{5}{*}{0.20} & 0.20 & 5 & $\begin{array}{l}\text { WRC } 107 \\
\text { Dodge } \\
\text { Eq. (lib) }\end{array}$ & $\begin{array}{l}-0.56 \\
-0.55\end{array}$ & $\begin{array}{l}0.34 \\
0.33\end{array}$ & $\begin{array}{r}-0.75 \\
-0.74 \\
0.81\end{array}$ & $\begin{array}{l}0.69 \\
0.69\end{array}$ \\
\hline & & 10 & $\begin{array}{l}\text { WRC } 107 \\
\text { Dodge } \\
\text { Iq. }(1,6)\end{array}$ & $\begin{array}{l}-2.06 \\
-2.03\end{array}$ & $\begin{array}{l}0.88 \\
0.92\end{array}$ & $\begin{array}{r}-2.53 \\
-2.50 \\
2.71\end{array}$ & $\begin{array}{l}2.20 \\
2.21\end{array}$ \\
\hline & & 20 & $\begin{array}{l}\text { WRC } 107 \\
\text { Dodge } \\
\text { Eq. (4b) }\end{array}$ & $\begin{array}{l}-7.19 \\
-7.25\end{array}$ & $\begin{array}{l}2.28 \\
2.38\end{array}$ & $\begin{array}{r}-8.45 \\
-7.52 \\
9.05\end{array}$ & $\begin{array}{l}6.91 \\
5.96\end{array}$ \\
\hline & . & 40 & $\begin{array}{l}\text { WRC } 107 \\
\text { Dodge } \\
\text { Eq. (4b) }\end{array}$ & $\begin{array}{l}-21.63 \\
-22.15 \\
30.2\end{array}$ & $\begin{array}{l}4.99 \\
4.29\end{array}$ & $\begin{array}{l}-22.87 \\
-19.76\end{array}$ & $\begin{array}{l}16.01 \\
12.77\end{array}$ \\
\hline & & 80 & $\begin{array}{l}\text { WRC } 107 \\
\text { Dodge } \\
\text { Eq. (4b) }\end{array}$ & $\begin{array}{l}-58.88 \\
-50.65 \\
101.0\end{array}$ & $\begin{array}{l}2.56 \\
4.25\end{array}$ & $\begin{array}{r}-52.56 \\
-48.48\end{array}$ & $\begin{array}{l}25.26 \\
21.75\end{array}$ \\
\hline
\end{tabular}

For longitudinal moment loading; $\mathrm{S}_{\ell}=6 \mathrm{M}_{\mathrm{L}} /\left(8 \mathrm{~L}_{1} \mathrm{~L}_{2}{ }^{2}\right)$; for subscript notation see footnote a of Table 10. 
Table 13. Comparisons for circumferential mament loadings on square loaded areas ${ }^{a}$

\begin{tabular}{|c|c|c|c|c|c|c|c|}
\hline$B_{3}$ & $B_{2}$ & $\gamma$ & Method & $\sigma_{\varnothing 0} / \dot{s}_{\ell}$ & $\sigma_{\varphi, i} / s_{\ell}$ & $\sigma_{x O} / s_{\ell}$ & $\sigma_{x i} / \dot{S}_{\ell}$ \\
\hline \multirow[t]{5}{*}{0.05} & 0.05 & 5 & $\begin{array}{l}\text { WRC } 107 \\
\text { Dodge } \\
\text { Eq. (4c) }\end{array}$ & $\begin{array}{c}-0.05 \\
-0.05 \\
0.066\end{array}$ & $\begin{array}{l}0.05 \\
0.05\end{array}$ & $\begin{array}{l}-0.03 \\
-0.03\end{array}$ & $\begin{array}{l}0.03 \\
0.03\end{array}$ \\
\hline & . & 10 & $\begin{array}{l}\text { WRC } 107 \\
\text { Dodge } \\
\text { Eq. ( } 4 \mathrm{c})\end{array}$ & $\begin{array}{r}-0.21 \\
-0.20 \\
0.25\end{array}$ & $\begin{array}{l}0.21 \\
0.20\end{array}$ & $\begin{array}{l}-0.13 \\
-0.13\end{array}$ & $\begin{array}{l}0.13 \\
0.12\end{array}$ \\
\hline & & 20 & $\begin{array}{l}\text { WRC } 107 \\
\text { Dodge } \\
\text { Eq. (4c) }\end{array}$ & $\begin{array}{r}-0.85 \\
-0.78 \\
0.92\end{array}$ & $\begin{array}{r}0.83 \\
.0 .75 \\
\end{array}$ & $\begin{array}{l}-0.51 \\
-0.50\end{array}$ & $\begin{array}{l}0.50 \\
0.47\end{array}$ \\
\hline & & 40 & $\begin{array}{l}\text { WRC } 107 \\
\text { Dodge } \\
\text { Eq. (4c) }\end{array}$ & $\begin{array}{r}-3.43 \\
-3.09 \\
3.43\end{array}$ & $\begin{array}{l}3.29 \\
2.91\end{array}$ & $\begin{array}{l}-2.08 \\
-1.99\end{array}$ & $\begin{array}{l}1.89 \\
1.78\end{array}$ \\
\hline & & 80 & $\begin{array}{l}\text { WRC } 107 \\
\text { Dodge } \\
\text { Eq. ( } 4 \mathrm{c})\end{array}$ & $\begin{array}{c}-13.37 \\
-12.12 \\
12.8\end{array}$ & $\begin{array}{l}12.49 \\
11.05\end{array}$ & $\begin{array}{l}-8.01 \\
-7.80\end{array}$ & $\begin{array}{l}6.84 \\
6.45\end{array}$ \\
\hline \multirow[t]{5}{*}{0.10} & 0.10 & 5 & $\begin{array}{l}\text { WRC } 107 \\
\text { Dodge } \\
\text { Eq. (4c) }\end{array}$ & $\begin{array}{r}-0.21 \\
-0.22 \\
0.30\end{array}$ & $\begin{array}{l}0.21 \\
0.21\end{array}$ & $\begin{array}{l}-0.14 \\
-0.13\end{array}$ & $\begin{array}{l}0.13 \\
0.12\end{array}$ \\
\hline & & 10 & $\begin{array}{l}\text { WRC. } 107 \\
\text { Dodge } \\
\text { Eq. (4c) }\end{array}$ & $\begin{array}{r}-0.85 \\
-0.87 \\
1.13\end{array}$ & $\begin{array}{l}0.81 \\
0.83\end{array}$ & $\begin{array}{l}-0.53 \\
-0.52\end{array}$ & $\begin{array}{l}0.48 \\
0.47\end{array}$ \\
\hline & & 20 & $\begin{array}{l}\text { WRC } 10 \% \\
\text { Dodge } \\
\text { Eq. (4c) }\end{array}$ & $\begin{array}{r}-3.32 \\
-3.42 \\
4.22\end{array}$ & $\begin{array}{l}3.08 \\
3.19\end{array}$ & $\begin{array}{l}-2.02 \\
-2.04\end{array}$ & $\begin{array}{l}1.70 \\
1.73\end{array}$ \\
\hline & & 40 & $\begin{array}{l}\text { WRC } 107 \\
\text { Dodge } \\
\text { Eq. (4c) }\end{array}$ & $\begin{array}{c}-12.93 \\
-13.21 \\
15.7\end{array}$ & $\begin{array}{l}11.65 \\
11.92\end{array}$ & $\begin{array}{l}-7.82 \\
-7.86\end{array}$ & $\begin{array}{l}6.01 \\
6.04\end{array}$ \\
\hline & & 80 & $\begin{array}{l}\text { WRC } 107 \\
\text { Dodge } \\
\text { Eq. (4c) }\end{array}$ & $\begin{array}{c}-47.23 \\
-49.37 \\
58.7\end{array}$ & $\begin{array}{l}40.83 \\
42.88\end{array}$ & $\begin{array}{l}-29.08 \\
-29.17\end{array}$ & $\begin{array}{l}19.05 \\
19.04\end{array}$ \\
\hline \multirow[t]{4}{*}{0.20} & 0.20 & 5 & $\begin{array}{l}\text { WRC } 107 \\
\text { Dodge } \\
\text { Eq. (4c) }\end{array}$ & $\begin{array}{r}-0.84 \\
-0.86 \\
1.24\end{array}$ & $\begin{array}{l}0.78 \\
0.80\end{array}$ & $\begin{array}{r}-0.53 \\
-0.53\end{array}$ & $\begin{array}{l}0.43 \\
0.44\end{array}$ \\
\hline & & 10 & $\begin{array}{l}\text { WRC } 107 \\
\text { Dodge } \\
\text { Eq. (4c) }\end{array}$ & $\begin{array}{r}-3.15 \\
-3.39 \\
4.64\end{array}$ & $\begin{array}{l}2.93 \\
3.05\end{array}$ & $\begin{array}{l}-2.02 \\
-2.06\end{array}$ & $\begin{array}{l}1.50 \\
1.56\end{array}$ \\
\hline & & 20 & $\begin{array}{l}\text { WRC } 107 \\
\text { Dodge } \\
\text { Eq. (4c) }\end{array}$ & $\begin{array}{c}-12.06 \\
-12.45 \\
17.3\end{array}$ & $\begin{array}{l}10.46 \\
10.78\end{array}$ & $\begin{array}{l}-7.53 \\
-7.58\end{array}$ & $\begin{array}{l}4.76 \\
4.87\end{array}$ \\
\hline & & 40 & $\begin{array}{l}\text { WRC } 107 \\
\text { Dodge } \\
\text { Eq. (4c) }\end{array}$ & $\begin{array}{r}-41.30 \\
-43.87 \\
64.7\end{array}$ & $\begin{array}{l}34.47 \\
36.70\end{array}$ & $\begin{array}{l}-25.34 \\
-26.54\end{array}$ & $\begin{array}{l}12.54 \\
13.00\end{array}$ \\
\hline . & 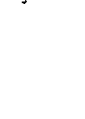 & 80 & $\begin{array}{l}\text { WRC } 107 \\
\text { Dodge } \\
\text { Eq. (4c) }\end{array}$ & $\begin{array}{r}-137.7 \\
-142.5 \\
241.0\end{array}$ & $\begin{array}{l}112.1 \\
117.4\end{array}$ & $\begin{array}{l}-86.02 \\
-85.72\end{array}$ & $\begin{array}{l}24.58 \\
24.96\end{array}$ \\
\hline
\end{tabular}

For circumferential moment loading, $\mathrm{S}_{\ell}=6 \mathrm{M}_{C} /\left(8 \mathrm{~L}_{1}{ }^{2} \mathrm{~L}_{2}\right)$; for subscript notation see footnote a of Table 10. 
Table 14. Comparisons for longitudinal moment loadings on rectangular loaded areas

\begin{tabular}{|c|c|c|c|c|c|c|c|}
\hline$\beta_{1}$ & $\beta_{2}$ & $\gamma$ & Method & $\sigma_{\varnothing 0} / s_{\ell}$ & $\sigma_{\phi_{i}} / s_{\ell}$. & $\sigma_{x O} / s_{l}$ & $\sigma_{x i} / s_{\ell}$ \\
\hline \multirow[t]{5}{*}{0.05} & 0.20 & 5 & $\begin{array}{l}\text { WRC } 107 \\
\text { Dodge } \\
\text { Eq. (4b) }\end{array}$ & $\begin{array}{c}-0.107 \\
-0.240\end{array}$ & $\begin{array}{l}0.069 \\
0.183\end{array}$ & $\begin{array}{r}-0.239 \\
-0.242 \\
0.385\end{array}$ & $\begin{array}{l}0.233 \\
0.229\end{array}$ \\
\hline & & 10 & $\begin{array}{l}\text { WRC } 107 \\
\text { Dodge } \\
\text { F. (4b) }\end{array}$ & $\begin{array}{c}-0.416 \\
-0.425 \\
1.29\end{array}$ & $\begin{array}{l}0.180 \\
0.661\end{array}$ & $\begin{array}{l}-0.863 \\
-0.896\end{array}$ & $\begin{array}{l}0.827 \\
0.8 \cap 6\end{array}$ \\
\hline & & 20 & $\begin{array}{l}\text { WRC lo' } \\
\text { Dodge } \\
\text { Eq. (4b) }\end{array}$ & $\begin{array}{r}-1.51 \\
-3.43 \\
4.30\end{array}$ & $\begin{array}{l}0.368 \\
2.103\end{array}$ & $\begin{array}{l}-3.02 \\
-2.82\end{array}$ & $\begin{array}{l}2.84 \\
2.31\end{array}$ \\
\hline & & 40 & $\begin{array}{l}\text { WRC } 107 \\
\text { Dodge } \\
\text { Eq. (4b) }\end{array}$ & $\begin{array}{c}-5.54 \\
-11.85 \\
14.4\end{array}$ & $\begin{array}{l}0.0107 \\
6.77\end{array}$ & $\begin{array}{l}-3.85 \\
-8.59\end{array}$ & $\begin{array}{l}9.05 \\
6.06\end{array}$ \\
\hline & & 80 & $\begin{array}{l}\text { WRC } 107 \\
\text { Dodge } \\
\text { Eq. (4b) }\end{array}$ & $\begin{array}{c}-19.64 \\
-39.34 \\
47.9\end{array}$ & $\begin{array}{l}-4.44 \\
22.27\end{array}$ & $\begin{array}{l}-25.37 \\
-26.79\end{array}$ & $\begin{array}{l}22.56 \\
15.33\end{array}$ \\
\hline \multirow[t]{5}{*}{0.05} & 0.10 & 5 & $\begin{array}{l}\text { WRC } 107 \\
\text { Dodge } \\
\text { Dq. (4b) }\end{array}$ & $\begin{array}{l}-0.081 \\
=0.090\end{array}$ & $\begin{array}{l}0.073 \\
0.085\end{array}$ & $\begin{array}{r}-0.130 \\
-0.124 \\
0.197\end{array}$ & $\begin{array}{l}0.128 \\
0.122\end{array}$ \\
\hline & & 10 & $\begin{array}{l}\text { WRC } 107 \\
\text { Dodge } \\
\text { Eq. (4b) }\end{array}$ & $\begin{array}{l}-0.302 \\
-0.392\end{array}$ & $\begin{array}{l}0.256 \\
0.314\end{array}$ & $\begin{array}{r}-0.489 \\
-0.469 \\
0.658\end{array}$ & $\begin{array}{l}0.475 \\
0.450\end{array}$ \\
\hline & & 20 & $\begin{array}{l}\text { WRE IU'f } \\
\text { Dodge } \\
\text { Eq. (4b) }\end{array}$ & $\begin{array}{l}-1.1 .14 \\
-1.595\end{array}$ & $\begin{array}{l}0.910 \\
1.152\end{array}$ & $\begin{array}{c}-1.839 \\
-1.814 \\
2.20\end{array}$ & $\begin{array}{l}1.751 \\
1.692\end{array}$ \\
\hline & & 40 & $\begin{array}{l}\text { WRC } 107 \\
\text { Lodge } \\
\text { Eq. (4b) }\end{array}$ & $\begin{array}{l}-4.301 \\
-6.199\end{array}$ & $\begin{array}{l}2.992 \\
3.894\end{array}$ & $\begin{array}{r}-6.63 \\
-6.43 \\
7.34\end{array}$ & $\begin{array}{l}6.17 \\
5.70\end{array}$ \\
\hline & & 80 & $\begin{array}{l}\text { WRC } 107 \\
\text { Dodge } \\
\text { E'q. (4b) }\end{array}$ & $\begin{array}{c}-15.18 \\
-22.63 \\
24.5\end{array}$ & $\begin{array}{r}8.91 \\
12.11\end{array}$ & $\begin{array}{l}-21.45 \\
-20.97\end{array}$ & $\begin{array}{l}19.0 \\
17.08\end{array}$ \\
\hline 0.20 & 0.10 & 5 & $\begin{array}{l}\text { WRC } 107 \\
\text { Dodge } \\
\text { Eq. (4b) }\end{array}$ & $\begin{array}{l}-0.238 \\
-0.155\end{array}$ & $\begin{array}{l}0.192 \\
0.108\end{array}$ & $\begin{array}{r}-0.285 \\
-0.293 \\
0.368\end{array}$ & $\begin{array}{l}0.268 \\
0.287\end{array}$ \\
\hline
\end{tabular}


Table 14 (continued)

\begin{tabular}{|c|c|c|c|c|c|c|c|}
\hline$\beta_{1}$ & $\beta_{2}$ & $\gamma$ & Method & ${ }^{\sigma} \varnothing_{0} / s_{\ell}$ & $\sigma_{\phi_{i}} / s_{l}$ & $\sigma_{x o} / s_{\ell}$ & $\sigma_{x i} / s_{\ell}$ \\
\hline & & 10 & $\begin{array}{l}\text { WRC } 107 \\
\text { Dodge } \\
\text { Eq. (4b) }\end{array}$ & $\begin{array}{l}-0.897 \\
-0.632\end{array}$ & $\begin{array}{r}0.621 \\
0.357\end{array}$ & $\begin{array}{r}-1.05 \\
-1.12 \\
1.23\end{array}$ & $\begin{array}{l}0.94 \\
1.07\end{array}$ \\
\hline & & 20 & $\begin{array}{l}\text { WRC } 107 \\
\text { Dodge } \\
\text { Eq. (4b) }\end{array}$ & $\begin{array}{l}-3.46 \\
-2.48\end{array}$ & $\begin{array}{l}2.07 \\
0.96\end{array}$ & $\begin{array}{r}-3.69 \\
-3.97 \\
4.11\end{array}$ & $\begin{array}{l}3.12 \\
3.66\end{array}$ \\
\hline & & 40 & $\begin{array}{l}\text { WRC } 107 \\
\text { Dodge } \\
\text { Eq. (4b) }\end{array}$ & $\begin{array}{r}-12.28 \\
-9.00\end{array}$ & $\begin{array}{l}6.09 \\
1.54\end{array}$ & $\begin{array}{c}-12.12 \\
-12.67 \\
13.7\end{array}$ & $\begin{array}{r}9.24 \\
11.11\end{array}$ \\
\hline & & 80 & $\begin{array}{l}\text { WRC } 107 \\
\text { Dodge } \\
\text { Eq. (4b) }\end{array}$ & $\begin{array}{l}-41.57 \\
-28.55\end{array}$ & $\begin{array}{r}16.43 \\
-25.43\end{array}$ & $\begin{array}{c}-32.80 \\
-34.06 \\
45.8\end{array}$ & $\begin{array}{l}19.91 \\
27.40\end{array}$ \\
\hline \multirow[t]{5}{*}{0.40} & 0.10 & 5 & $\begin{array}{l}\text { WRC } 107 \\
\text { Dodge } \\
\text { Eq. (4b) }\end{array}$ & $\begin{array}{l}-0.380 \\
-0.168\end{array}$ & $\begin{array}{l}0.304 \\
0.090\end{array}$ & $\begin{array}{r}-0.379 \\
-0.365 \\
0.383\end{array}$ & $\begin{array}{l}0.345 \\
0.360\end{array}$ \\
\hline & & 10 & $\begin{array}{l}\text { WRC } 107 \\
\text { Dodge } \\
\text { Eq. (4b) }\end{array}$ & $\begin{array}{l}-1.42 \\
-0.679\end{array}$ & $\begin{array}{l}0.980 \\
2.38\end{array}$ & $\begin{array}{r}-1.29 \\
-1.32 \\
1.28\end{array}$ & $\begin{array}{l}1.09 \\
1.27\end{array}$ \\
\hline & & 20 & $\begin{array}{l}\text { WRC } 107 \\
\text { Dodge } \\
\text { Eq. (4b) }\end{array}$ & $\begin{array}{l}-5.23 \\
-2.57\end{array}$ & $\begin{array}{l}3.25 \\
3.07\end{array}$ & $\begin{array}{r}-4.44 \\
-4.38 \\
4.28\end{array}$ & $\begin{array}{l}3.40 \\
4.12\end{array}$ \\
\hline & & 40 & $\begin{array}{l}\text { WRC } 107 \\
\text { Dodge } \\
\text { Eq. (4b) }\end{array}$ & $\begin{array}{r}-17.65 \\
-8.65\end{array}$ & $\begin{array}{l}10.54 \\
-1.405\end{array}$ & $\begin{array}{c}-13.90 \\
-12.45 \\
14.3\end{array}$ & $\begin{array}{r}9.15 \\
11.50\end{array}$ \\
\hline & & 80 & $\begin{array}{l}\text { WRC } 107 \\
\text { Dodge } \\
\text { Eq. (4b) }\end{array}$ & $\begin{array}{l}-53.72 \\
-25.91\end{array}$ & $\begin{array}{r}30.06 \\
-11.11\end{array}$ & $\begin{array}{c}-34.22 \\
-28.52 \\
47.7\end{array}$ & $\begin{array}{l}15.03 \\
26.40\end{array}$ \\
\hline
\end{tabular}

a For longitudinal moment loading, $S_{f}=6 M_{L} /\left(8 L_{1} L_{2}{ }^{2}\right)$; for subscript notation see footrote a of Table 10. 
Table 15. Comparisons for circumferential moment loadings on rectangular loaded areas

\begin{tabular}{|c|c|c|c|c|c|c|c|}
\hline$\beta_{1}$ & $\beta_{2}$ & $\gamma$ & Method & $\sigma_{\varnothing 0} / s_{\ell}$ & $\sigma_{\varnothing_{i}} / s_{\ell}$ & $\sigma_{x o} / s_{\ell}$ & $\sigma_{x i} / s_{l}$ \\
\hline \multirow[t]{5}{*}{0.05} & 0.20 & 5 & $\begin{array}{l}\text { WRC } 107 \\
\text { Dodge } \\
\text { Eq. (4c) }\end{array}$ & $\begin{array}{r}-0.100 \\
-0.101 \\
0.148\end{array}$ & $\begin{array}{l}0.098 \\
0.100\end{array}$ & $\begin{array}{l}-0.044 \\
-0.042\end{array}$ & $\begin{array}{l}0.042 \\
0.039\end{array}$ \\
\hline & & 10 & $\begin{array}{l}\text { WRC } 107 \\
\text { Dudje } \\
\text { Eq. (4c) }\end{array}$ & $\begin{array}{r}-0.399 \\
-0.403 \\
0.553\end{array}$ & $\begin{array}{l}0.393 \\
0.395\end{array}$ & $\begin{array}{r}-0.167 \\
0.161\end{array}$ & $\begin{array}{l}0.156 \\
0.147\end{array}$ \\
\hline & & 20 & $\begin{array}{l}\text { WRC } 107 \\
\text { Dodge } \\
\text { Eq. (4c) }\end{array}$ & $\begin{array}{r}-1.57 \\
-1.59 \\
2.06\end{array}$ & $\begin{array}{l}1.54 \\
1.55\end{array}$ & $\begin{array}{r}0.637 \\
-0.654\end{array}$ & $\begin{array}{l}0.563 \\
0.568\end{array}$ \\
\hline & & 40 & $\begin{array}{l}\text { WRC } 107 \\
\text { Dodge } \\
\text { Eq. (4c) }\end{array}$ & $\begin{array}{r}-6.34 \\
-6.22 \\
7.70\end{array}$ & $\begin{array}{l}6.20 \\
6.01\end{array}$ & $\begin{array}{l}-2.42 \\
-2.56\end{array}$ & $\begin{array}{l}2.01 \\
2.06\end{array}$ \\
\hline & & 80 & $\begin{array}{l}\text { WRC } 107 \\
\text { Dodge } \\
\text { Eq. (4G) }\end{array}$ & $\begin{array}{r}-23.7 \\
-22.9 \\
28.7\end{array}$ & $\begin{array}{r}23.12 \\
2.19\end{array}$ & $\begin{array}{l}-9.68 \\
-9.68\end{array}$ & $\begin{array}{l}7.38 \\
6.55\end{array}$ \\
\hline \multirow[t]{5}{*}{0.05} & 0.10 & 5 & $\begin{array}{l}\text { WRC } 107 \\
\text { Dodge } \\
\text { Eq. (4c) }\end{array}$ & $\begin{array}{r}-0.077 \\
-0.077 \\
0.104\end{array}$ & $\begin{array}{l}0.076 \\
0.076\end{array}$ & $\begin{array}{l}-0.039 \\
-0.038\end{array}$ & $\begin{array}{l}0.037 \\
0.037\end{array}$ \\
\hline & & 10 & $\begin{array}{l}\text { WRC } 107 \\
\text { Dodge } \\
\text { Eq. }(1,0)\end{array}$ & $\begin{array}{r}-0.310 \\
-0.312 \\
0.388\end{array}$ & $\begin{array}{l}0.305 \\
0.306\end{array}$ & $\begin{array}{l}-0.150 \\
-0.157\end{array}$ & $\begin{array}{l}0.143 \\
0.148\end{array}$ \\
\hline & & 20 & $\begin{array}{l}\text { WRO } 10 ' \% \\
\text { Dodge } \\
\text { Eq. }(4 \varepsilon)\end{array}$ & $\begin{array}{r}-1.20 \\
-1.23 \\
1.45\end{array}$ & $\begin{array}{l}1.17 \\
1.19\end{array}$ & $\begin{array}{l}-0.569 \\
-0.608\end{array}$ & $\begin{array}{l}0.523 \\
0.549\end{array}$ \\
\hline & & 40 & $\begin{array}{l}\text { WRC } 107 \\
\text { Dodge } \\
\text { Eq. (4c) }\end{array}$ & $\begin{array}{r}-4.98 \\
-4.95 \\
5.41\end{array}$ & $\begin{array}{l}4.81 \\
4.76\end{array}$ & $\begin{array}{l}-2.29 \\
-2.29\end{array}$ & $\begin{array}{l}2.02 \\
1.99\end{array}$ \\
\hline & & 80 & $\begin{array}{l}\text { WRC } 107 \\
\text { Dodge } \\
\text { Eq. (4c) }\end{array}$ & $\begin{array}{c}-18.62 \\
-19.32 \\
20.2\end{array}$ & $\begin{array}{l}17.68 \\
18.28\end{array}$ & $\begin{array}{l}-9.05 \\
-8.95\end{array}$ & $\begin{array}{l}7.27 \\
7.09\end{array}$ \\
\hline 0.20 & 0.10 & 5 & $\begin{array}{l}\text { WRC } 107 \\
\text { Dodge } \\
\text { Eq. (4c) }\end{array}$ & $\begin{array}{r}-0.447 \\
-0.525 \\
0.798\end{array}$ & $\begin{array}{l}0.395 \\
0.486\end{array}$ & $\begin{array}{l}-0.366 \\
-0.392\end{array}$ & $\begin{array}{l}0.310 \\
0.344\end{array}$ \\
\hline
\end{tabular}


Table 15 (continued)

\begin{tabular}{|c|c|c|c|c|c|c|c|}
\hline$\beta_{1}$ & $\beta_{2}$ & $\gamma$ & Method & ${ }^{\sigma} \varnothing_{0} / S_{l}$ & $\sigma_{\varnothing i} / s_{\ell}$ & $\sigma_{x 0} / S_{l}$ & $\sigma_{x i} / s_{\ell}$ \\
\hline & & 10 & $\begin{array}{l}\text { WRC } 107 \\
\text { Dodge } \\
\text { Eq. (4c) }\end{array}$ & $\begin{array}{r}-1.72 \\
-2.05 \\
2.98\end{array}$ & $\begin{array}{l}1.45 \\
1.82\end{array}$ & $\begin{array}{l}-1.41 \\
-1.51\end{array}$ & $\begin{array}{l}1.09 \\
1.24\end{array}$ \\
\hline & & 20 & $\begin{array}{l}\text { WRC } 107 \\
\text { Dodge } \\
\text { Eq. (4c) }\end{array}$ & $\begin{array}{l}-6.89 \\
-7.75 \\
11.1\end{array}$ & $\begin{array}{l}5.31 \\
6.50\end{array}$ & $\begin{array}{l}-5.27 \\
-5.66\end{array}$ & $\begin{array}{l}3.55 \\
4.13\end{array}$ \\
\hline & & 40 & $\begin{array}{l}\text { WRC } 107 \\
\text { Dodge } \\
\text { Eq. (4c) }\end{array}$ & $\begin{array}{r}-26.6 \\
-27.9 \\
41.5\end{array}$ & $\begin{array}{l}15.75 \\
21.74\end{array}$ & $\begin{array}{l}-18.49 \\
-20.03\end{array}$ & $\begin{array}{l}1.03 \\
1.21\end{array}$ \\
\hline & & 80 & $\begin{array}{l}\text { WRC } 107 \\
\text { Dodge } \\
\text { Eq. (4c) }\end{array}$ & $\begin{array}{l}-86.45 \\
-92.32 \\
155.0\end{array}$ & $\begin{array}{l}60.82 \\
66.77\end{array}$ & $\begin{array}{r}-63.63 \\
-64.69\end{array}$ & $\begin{array}{l}25.89 \\
28.41\end{array}$ \\
\hline \multirow[t]{5}{*}{0.40} & 0.10 & 5 & $\begin{array}{l}\text { WRC } 107 \\
\text { Dodge } \\
\text { Eq. }(4 c)\end{array}$ & $\begin{array}{r}-0.90 \\
-1.17 \\
1.83\end{array}$ & $\begin{array}{l}0.676 \\
1.011\end{array}$ & $\begin{array}{l}-0.815 \\
-0.830\end{array}$ & $\begin{array}{l}0.550 \\
0.617\end{array}$ \\
\hline & & 10 & $\begin{array}{l}\text { WRC } 107 \\
\text { Dodge } \\
\text { Eq. (4c) }\end{array}$ & $\begin{array}{r}-3.45 \\
-4.35 \\
6.84\end{array}$ & $\begin{array}{l}2.40 \\
3.56\end{array}$ & $\begin{array}{l}-3.05 \\
-3.00\end{array}$ & $\begin{array}{l}1.66 \\
1.91\end{array}$ \\
\hline & & 20 & $\begin{array}{l}\text { WRC } 107 \\
\text { Dodge } \\
\text { Eq. (4c) }\end{array}$ & $\begin{array}{r}-12.9 \\
-15.0 \\
25.5\end{array}$ & $\begin{array}{r}7.92 \\
11.66\end{array}$ & $\begin{array}{l}-12.91 \\
-10.11\end{array}$ & $\begin{array}{l}2.15 \\
4.96\end{array}$ \\
\hline & & 40 & $\begin{array}{l}\text { WRC } 107 \\
\text { Dodge } \\
\text { Eq. (4c) }\end{array}$ & $\begin{array}{r}-44.0 \\
-48.2 \\
95.3\end{array}$ & $\begin{array}{l}25.93 \\
36.67\end{array}$ & $\begin{array}{l}-35.7^{\prime 2} \\
-31.48\end{array}$ & $\begin{array}{r}9.79 \\
10.76\end{array}$ \\
\hline & & 80 & $\begin{array}{l}\text { WRC } 107 \\
\text { Dodge } \\
\text { Eq. (4c) }\end{array}$ & $\begin{array}{r}-149.2 \\
-142.5 \\
356.0\end{array}$ & $\begin{array}{c}96.75 \\
108.1\end{array}$ & $\begin{array}{l}-113.6 \\
-92.52\end{array}$ & $\begin{array}{l}21.39 \\
12.84\end{array}$ \\
\hline
\end{tabular}

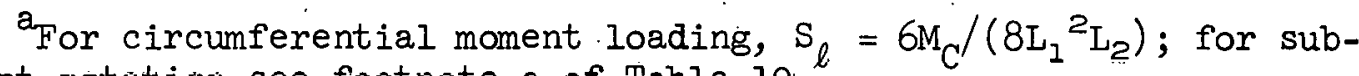
script notation see footnote a of Table 10." 
where $\beta_{1}>\beta_{2}$, the WRC 107 method tends to underestimate the magnitude of the maximum stress. For circumferential moment loadings, Eq. (4c) tends to be conservative over the entire parameter range.

In summary, for both thrust and moment loadings, comparisons among the WRC 107 method, Dodge's direct calculations ${ }^{2}$ of Bijlaard's analysis, 6 and the stress-index equations developed in Ref. 2 [Eqs. (4a), (4b), and (4c) herein] show that the stress-index method tends always to be conservative. For square loaded areas, the WRC 107 method gives about the same results as the stress-index method. For loaded areas which are not square (i.e., $\beta_{1} \neq \beta_{2}$ ), Bulletin 107 uses an approximate method (based on Ref. 7) which appears to be adequate for thrust loadings over the parameter range considered and fair for moment loadings within the parameter range $1 / 4 \leq \beta_{1} / \beta_{2} \leq 4$; within this range the magnitude is conservative, but the location and direction may be in error. On the other hand, the WRC 107 method may be misleading for moment loadings on integral lugs which are long and narrow (i.e., for cases where $\beta_{1} / \beta_{2}<1 / 4$ or $\beta_{1} / \beta_{2}>4$ ).

\section{Local Btresses}

The $\mathrm{C}$ indices represent a combination of membrane stresses and linear through-the-wall-thickness bending stresses. They dn not, however, provide any allowance f'or the highly localized stresses that would be present at the toe of the fillet weld joining the lug to the pipe surface. In the Code's analysis procedure of $\mathrm{NB}-3650$, these stresses are evaluated by means of $K$ indices. Different $K$-index values are provided in Table NB-3683.2-1 for butt welds which have been ground smooth and those which have been left as welded. Thus, in keeping with the philosowhy of $\mathrm{NB}-3650, \mathrm{~K}_{l}$ indices are proposed for lugs with either as-welded fillet welds or with ground fillet welds as shown in Fig. 3 . The $\mathrm{K}_{\ell}$ indices will be used in defining the added term $\left(S_{p}\right)$ lug in Section 6 .

An appropriate $\mathrm{K}_{\ell}$ index for an as-welded lug is deemed to be that presently given by $K_{2}$ in Table NB-3683.2-1 for girth fillet welds for socket-weld fittings, slip-on flanges, and socket-welding flanges. The background and justification for this case, where $K_{2}$ is set equal to 2.0, is given in Ref. 8. Thus for as-welded lugs, $\mathrm{K}_{l}=2.0$ is proposed. 

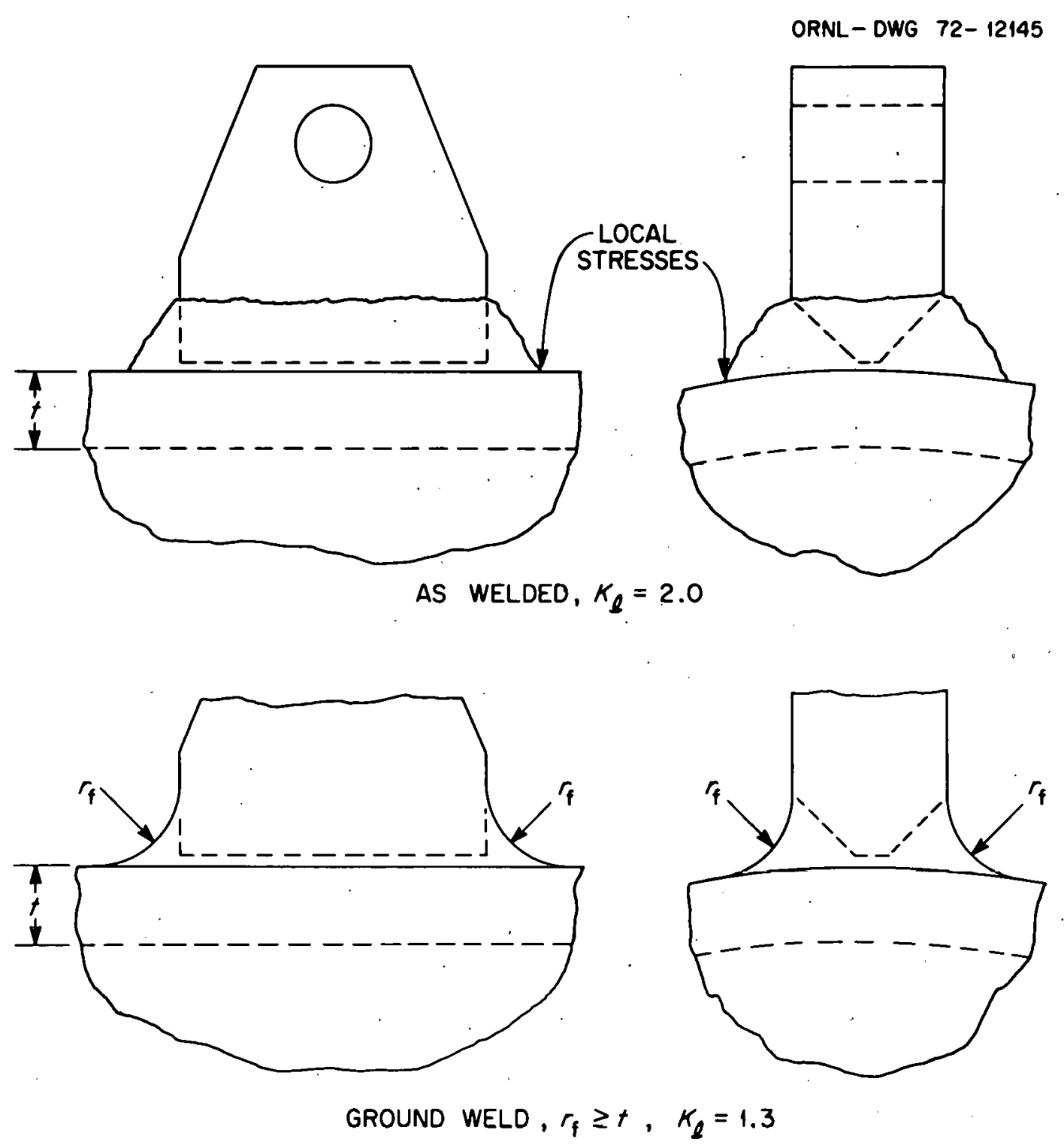

Fig. 3. As-welded and ground welds between lug and pipe.

If the fillet weld joining the lug to the pipe is ground to a smooth radius $r_{f}$ as shown in Fig. 3, and if $r_{f} \geq t$ (the wall thickness of the pipe), then $K_{\ell}=1.3$ would be appropriate. This value is based on the bending stress-concentration factors shown in Fig. 4 for $r / t \geq 1.0$. These curves were presented by Wichman, Hopper, and Mershon ${ }^{4}$ in WRC Bulletin 107. Use of the bending curve was chosen since the major part of the surface stress at the toe of the weld is a bending stress (see, for example, Tables 5 to 7 ). 


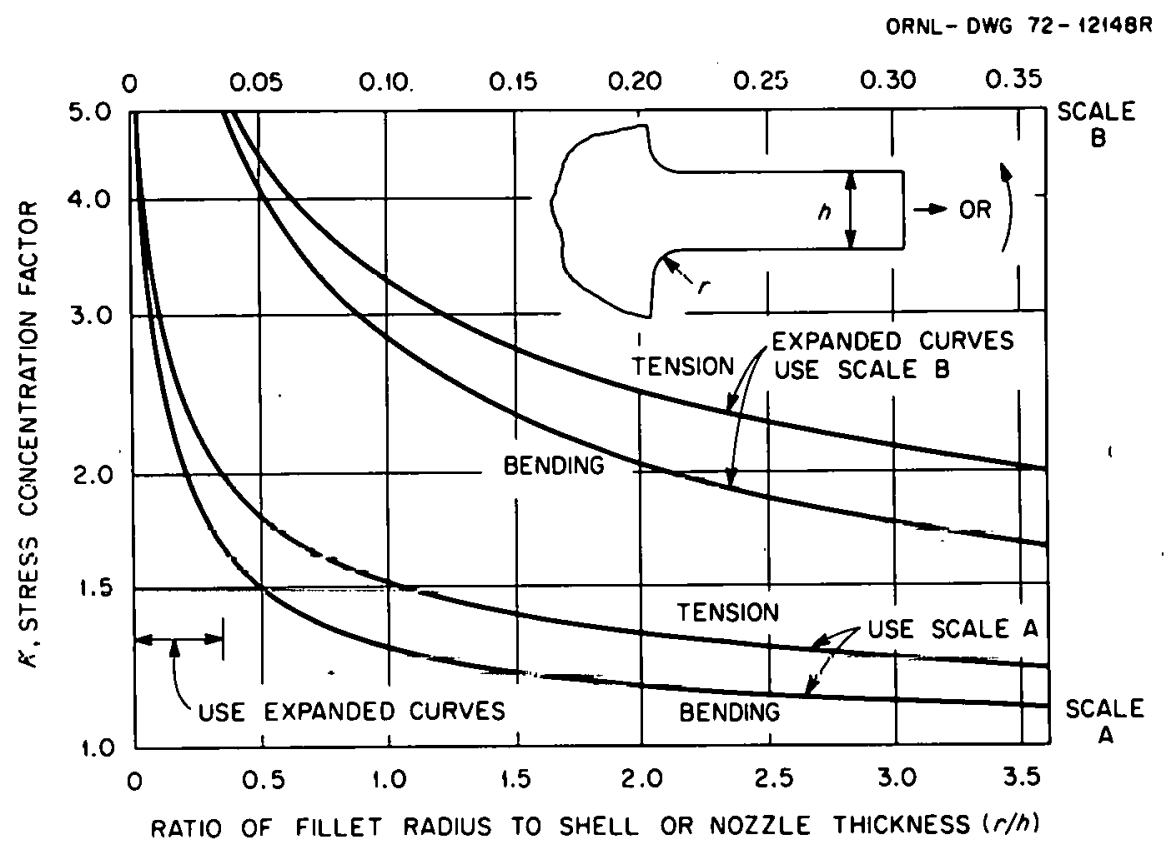

Fig. 4. Stress concentration factors from Ref. 4.

It may be noted in Appendix $B$ that for moment loadings there are a number of cases where the maximum surface stress is well outside the loaded area. For these particular cases the local stress at the toe of the fillet weld would not be at the same position as the maximum surface stress. For conservatism, however, we will assume that the surface stress at the toe of the fillet weld is equal to the maximum surface stress, wherever that maximum occurs.

\section{SHE $\Lambda R$ AND TORSTONAT. T.OADS}

A complete set of external loads which may act on a lug consists of three moments and three forces. Two of the moments, $\mathrm{M}_{\mathrm{L}}$ and $\mathrm{M}_{\mathrm{C}}$, and one of the forces, radial thrust $W$, were discussed in the previous section. This section covers the torsional moment $M_{T}$ and the two shear forces $Q_{1}$ and $Q_{2}$ illustrated in Fig. 5. Equations for calculating the shear stresses $\tau_{1}$ and $\tau_{2}$ in the pipe wall (also shown in Fig. 5) due to the shear loads 


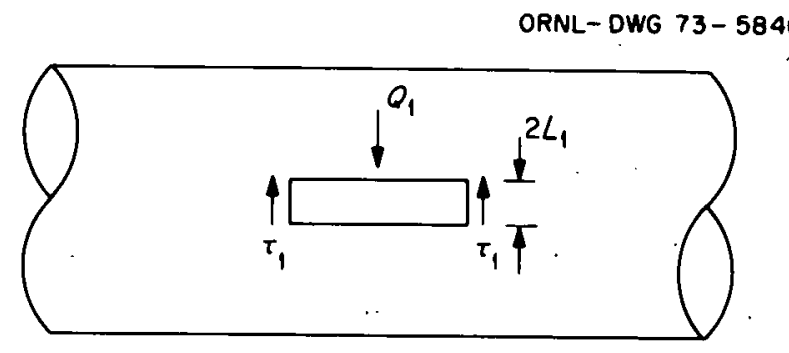

(a) SHEAR FORCE LOAD $Q_{1}$

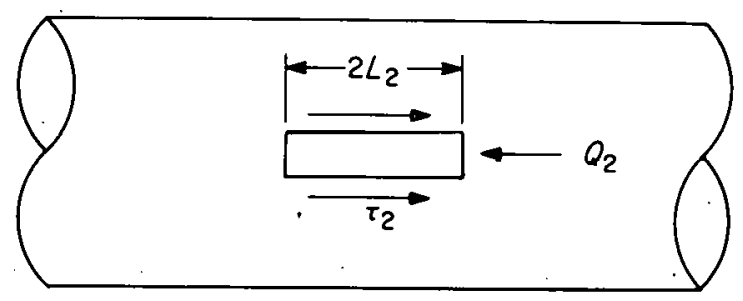

(b) SHEAR FORCE LOAO $\mathrm{O}_{2}$

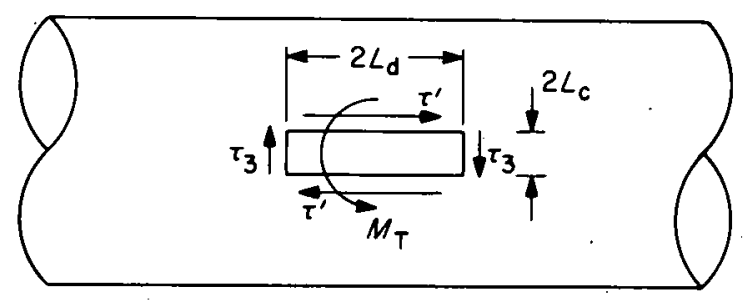

(c) TORSIONAL MOMENT LOAD $M_{T}$

Fig. 5. Representation of the nomenclature for shear-force and torsional-moment loadings on a lug.

$Q_{1}$ and $Q_{2}$ are given in Ref. 4:

$$
\begin{aligned}
& \tau_{1}=\frac{Q_{1}}{4 L_{1} t}, \\
& \tau_{2}=\frac{Q_{2}}{4 L_{2} t}:
\end{aligned}
$$

The concept behind these equations is that the shear load is balanced by membrane shear. stresses in the pipe wall parallel to the edges of the lug. 
A similar equation can be derived for the shear stress $\tau_{3}$ in the pipe wall due to the torsional moment $\mathrm{M}_{\mathrm{T}}$ by writing the force balance equation for the stresses $\tau_{3}$ and $t^{\prime}$ shown in Fig. 5c. Assume that $\tau_{3}$ and $t^{\prime}$ are constant along the short edges $\left(2 \mathrm{~L}_{c}\right)$ and the long edges $\left(2 \mathrm{~L}_{d}\right)$ of the lug, respectively, and that the shear forces acting on the short edges are equal to the shear forces acting on the long edges. That is, $2 \mathrm{~L}_{\mathrm{d}} t \tau^{\prime}=$ $2 L_{c} t T_{3} ; I_{c} \leq I_{d}$. Then, summing moments gives

$$
M_{T}=\left(2 L_{c} t T_{B}\right)\left(2 L_{d}\right)+\left(2 L_{d} t\right)\left(T_{3} L_{c} / L_{d}\right)\left(2 L_{c}\right)
$$

Solving this equation for $\tau_{3}$ and multiplying the result by 2.0 to account for the fact that the shear stress is not uniformly distributed gives an estimate for the maximum shear stress in the pipe wall due to a torsional moment $\mathrm{M}_{\mathrm{T}}$ :

$$
\tau_{3}=\frac{M_{T}}{2 L_{c} L_{d}\left(I+I_{c} / L_{d}\right) t},
$$

where $L_{c}=\min \left(L_{1}, L_{2}\right)$ and $L_{d}=\max \left(I_{1}, L_{2}\right)$.

Lt should be noted that Eqs. (LU) to (L) should give conservative estimates for the maximum shear stresses in the pipe wall. They are obviously inadequate, however, for the maximum shear stress in the lug at the interface when either $\mathrm{L}_{1}$ or $\mathrm{L}_{2}$ is less than the pipe wall thickness $t$. In order to cover both the pipe and the pipe-lug interface, Eqs. (10) and (11) should be replaced by

$$
r_{1}=\frac{Q_{1}}{4 L_{1} L_{0}},
$$

where $L_{a}$ is taken as the smallex of $L_{2}$ and $t$, and

$$
r_{2}=\frac{Q_{c}}{4 L_{2} L_{b}},
$$

where $L_{b}$ is taken as the smaller of $L_{1}$ and $t$. 
The maximum shear stress in a rectangular bar under torsional loading is given by Timoshenko and Goodier ${ }^{\ominus}$ as

$$
\tau_{3_{\max }}=\frac{\mathrm{M}_{\mathrm{T}}}{8 \mathrm{k}_{2} \mathrm{~L}_{\mathrm{c}}{ }^{2} \mathrm{~L}_{\mathrm{d}}},
$$

where the factor $k_{2}$ is tabulated as a function of $\mathrm{L}_{d} / \mathrm{L}_{c}$ over the range $1.0 \leq \mathrm{L}_{\mathrm{d}} / \mathrm{L}_{\mathrm{c}} \leq \infty$. An approximate fit within the range $1.0 \leq \mathrm{L}_{\mathrm{d}} / \mathrm{I}_{\mathrm{c}} \leq 10$ is given by

$$
8 \mathrm{k}_{2}=1.57+0.093\left(L_{d} / L_{c}\right)
$$

The approximation agrees with Ref. 9 at $\mathrm{L}_{\mathrm{d}} / \mathrm{L}_{\mathrm{c}}=1.0$ and 10 and is up to $16 \%$ conservative for intermediate values. Thus, the maximum shear stress in the lug due to a torsional moment $\mathrm{M}_{\mathrm{T}}$ is approximately

$$
\tau_{3}=\frac{M_{T}}{\left(1.57+0.093 L_{d} / L_{c}\right) L_{c}{ }^{2} L_{d}} .
$$

In application, $\tau_{3}$ should be taken as the greater of the values calculated by Eqs. (12) and (15) in order to cover both the pipe wall and the lug-pipe interface.

These expressions for $\tau_{1}, \tau_{2}$, and $\tau_{3}$, multiplied by 2.0 to convert from maximum shear stress to stress intensities, will be used in section 6 in defining the terms $\left(P_{L}+P_{b}\right)_{\text {lug }},\left(S_{n}\right)_{\text {lug' }}$ and $\left(S_{p}\right)_{\text {lug }}$.

\section{INTERIAL PRESSURE}

Internal pressure acting in a pipe with an integral attachment will produce local stresses in the pipe because of the resistance to expansion of the lug. A rough estimate of these stresses can be obtained from the data given by Van Dyke 10 for a rigid circular insert in a cylindrical shell with internal pressure loading. The stresses are a function of the parameter 8 , defined as:

$$
\delta^{2}=\frac{a^{2} \sqrt{12\left(1-v^{2}\right)}}{8 r t}
$$


where

$$
\begin{aligned}
& a=\text { radius of rigid circular insert, } \\
& v=\text { Poisson's ratio, } \\
& r=\text { cylindrical shell radius, } \\
& t=\text { cylindrical shell wall thickness. }
\end{aligned}
$$

For Poisson's ratio of $0.3, \delta=0.643(\mathrm{a} / \mathrm{r}) \sqrt{\mathrm{r} / \mathrm{t}}$.

Membrane stresses at $\theta=0$ and $90^{\circ}$ are plotted in Fig. 6. Membrane stresses at other values of $\theta$ lie between those shown. It may be noted that for small values of $\delta$ the membrane stresses are the same as those for a rigid insert in a flat plate with a 2-to-l tensile stress field.

Except for values of $\delta$ less than about 0.4 , the maximum surface stress (membrane plus bending) occurs at $\theta=0$. This stress is also shown in Fig. 6. The maximum surface stress for values of $\delta$ up to 2.0 is reasonably well represented by the equation:

$$
\begin{aligned}
\frac{\sigma_{m}}{\mathrm{pD}_{\mathrm{o}} / 2 t} & =1.5+1.38^{2} \\
& =1.5+0.537(\mathrm{a} / \mathrm{r})^{2}(\mathrm{r} / \mathrm{t}),
\end{aligned}
$$

which is also shown in Fig. 6.

Application of the Van Dyke analysis for a rigid circular insert to lugs rẹuirès some ènginèering judgment as to what is to be used as the equivalent of $(a / r)$ for lugs with dimensions $\beta_{1}$ and $\beta_{2}$. For lugs with $\beta_{1}=\beta_{2}$, it would appear appropriate to let $\beta_{1}=\beta_{2}=(a / r)$ in Eq. (17); however, for $\beta_{1} \neq \beta_{2} ;$ an appropriate value for $(a / r)$ is not obvious. Unfortunately, neither a directly applicable analysis nor relevant test data are available. Either the analysis or the test data should be developed. In the meantime, it is considered adequately conservative to let $(a / r)$ in Eq. (17) be equal to $\left(\beta_{1} \beta_{2}\right)^{1 / 2}$.

With the limitation of $\beta_{1} \beta_{2} \leq 0.075$ and $D_{0} / t \leq 100$ (recommended in Section 2, Thrust and Moment Loads), the largest value of $\delta$ will be $0.643 \times \sqrt{0.075} \times \sqrt{50}=1.245$ and the maximum stress, as determined by Eq. (17), is $3.516 \mathrm{pD}_{\mathrm{o}} / 2 \mathrm{t}$.

The stresses defined by Eq. (17) damp out within a short distance from the insert and also decrease rapidly as $\theta$ varies from 90 to $0^{\circ}$. Thus even if the maximum values exceed the yield strength of the material, 


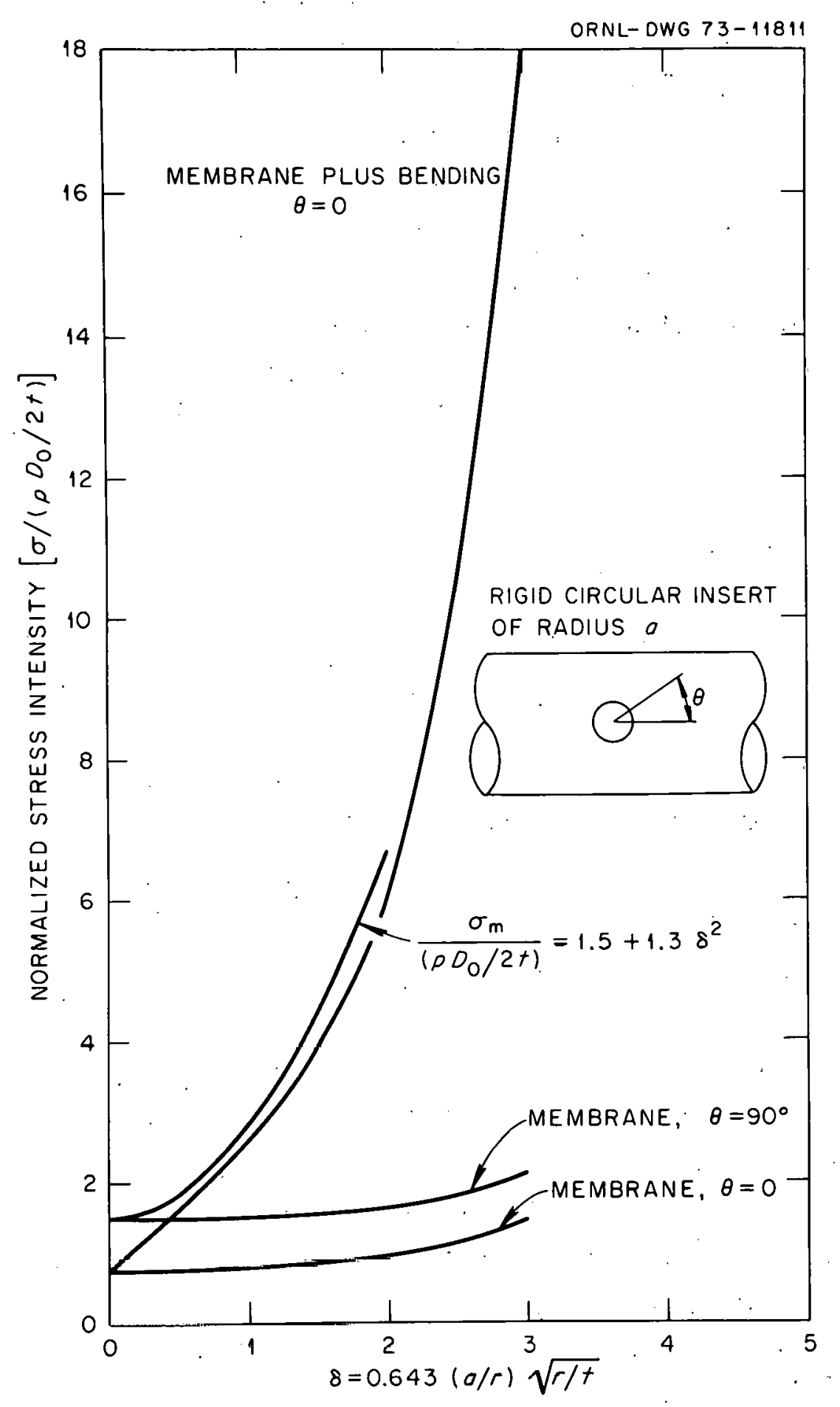

Fig. 6. Stresses at the edge of a rigid circular insert in a cylindrical shell with pressure loading. 
the maximum strains will be limited by the surrounding elastic material. For this reason, it seems appropriate to consider the stresses defined by Eq. (17) as peak stresses.

At the toe of the fillet weld, the maximum stress may be intensified if the weld is not ground smooth. Therefore, different values will be assigned for the stress index $\mathrm{K}_{\ell \mathrm{p}}$ (local stress at the lug due to internal pressure), depending upon whether the fillet weld is ground smooth or not, in the same manner as is done for $\mathrm{K}_{\ell}$ for moment loadings. The peak-stress term to be included in $s_{p}$ tor internal pressure is therefore

$$
\sigma_{p}-k_{\ell_{p}} \frac{p D_{n}}{2 t} .
$$

For as-welded fillet welds the index $K_{\ell \cdot \mathrm{p}}$ is thus

$$
\begin{aligned}
\mathrm{K}_{\ell p} & =\mathrm{K}_{\ell}\left(1.5+1.30^{2}\right) \\
& =2.0\left(1.5+0.537 \beta_{1} \beta_{2} \gamma\right),
\end{aligned}
$$

where the value of $\mathrm{K}_{\ell}=2.0$ is taken from the previous section and the remainder is taken from Eq. (17). Similarly for ground fillet welds

$$
\mathrm{K}_{\ell \mathrm{p}}=1.3\left(1.5+0.537 \beta_{1} \beta_{2} y\right),
$$

where $\mathrm{K}_{\ell}=1.3$ is the value assigned in the previous section for ground welds.

So far as gross plastic yielding is concerned, the presence of a lug attachment will not adversely affect the behavior of the component; hence, a primary-stress index $\mathrm{B}_{\ell p}$ for lugs is taken as zero. Recall that B-type indices are used in Eq. (C9) for primary-stress evaluation; $\mathrm{B}_{\ell}$-type indices are used to define the added term $\left(P_{L}+P_{b}\right)_{l u g}$ discussed in Section 6. Similarly, additional primary-plus-secondary stresses due to internal pressure will be negligible; thus an appropriate value for $\mathrm{C}_{\ell_{\mathrm{p}}}$ is also zero. 


\section{THERMAL GRADIENTS}

If the temperature of the lug is different from that of the pipe, the difference in thermal expansions will induce stresses in the pipe wall around the lug. Since these local stresses will damp out within a short distance from the lug, they can be classified as peak stresses and represented by K-type indices to be used in defining the term $\left(S_{p}\right)$ Iug ${ }^{\text {. Ther- }}$ mal stress contributions to the terms $\left(P_{I}+P_{b}\right)_{l u g}$ and $\left(S_{n}\right)_{l u g}$ will be taken as zero, as was done in the previous section for local-pressure stresses.

In general, the temperature gradients in the vicinity of the lug will form a rather complex pattern. However, in keeping with current Code practice, it will be assumed that each part is at some average temperature and the thermal stresses will be estimated accordingly. The average temperature of the portion of the lug within $2 t$ of the surface of the pipe is defined as $\mathrm{T}_{\ell}$, and the average temperature of the pipe under the Iug and within a distance of $\sqrt{r t}$ from the edge of the lug is defined as $T_{W}$. An approximate estimate of the maximum thermal stresses can be obtained by assuming that the lug is an elliptical insert at temperature $\mathrm{T}_{\ell}$ in an infinite flat plate at temperature $\mathrm{T}_{\mathrm{W}}$ and that the lug and weld metal have the same modulus of elasticity $E$ and coefficient of thermal expansion $\alpha$ as the pipe. Lugs that are long compared with their width will be covered by assuming that the major axis of the elliptical area is large compared with the minor axis. For this case Goodier ${ }^{11,12}$ gives the magnitude of the maximun thermal stress as

$$
\sigma_{\mathrm{T}}=E \alpha\left|\mathrm{T}_{\ell}-\mathrm{T}_{\mathrm{W}}\right|
$$

The thermal stresses may also be intensified at the toe of the fillet weld for the same reasons given earlier for thrust and/or moment loads and internal pressure. It is therefore recommended that the same values be used for the peak thermal stress index $\mathrm{K}_{\ell \mathrm{T}}$ as were recommended for the other loadings (i.e., $K_{\ell T}=K_{\ell}=2.0$. for as-welded fillet welds, and $\mathrm{K}_{\ell \mathrm{T}}=\mathrm{K}_{\ell}=1.3$ for ground fillet welds). The additament $\left(\mathrm{s}_{\mathrm{p}}\right)_{\text {lug }}$ will thus 
incorporate the thermal-stress term

$$
\sigma_{\mathrm{T}}=\mathrm{K}_{\ell} \mathrm{E} \alpha\left|\mathrm{T}_{\ell}-\mathrm{T}_{\mathrm{W}}\right|
$$

\section{CODE USE OF STRESS INDICES}

The Code gives stress indices for a number of piping components in Table NB-3683.2-1. Since this table and its footnotes are already quite lengthy and involved and since the evaluation of stresses at lugs involves an almost independent set of loadings, it is deemed appropriate to add a new paragraph, NB-3683.3, Indices for Integral Structural Attachments. The proposed wording for this new paragraph is included herein as Appendix $A$. The general intent is to "add on" appropriate terms identified earlier as $\left(P_{L}+P_{b}\right)_{\text {lug }},\left(S_{n}\right)_{l u g}$, and $\left(S_{p}\right)_{l u g}$ to Code equations (C9), ( $\mathrm{ClO}$ ), and ( $\mathrm{Cll}$ ) respectively. In addition, the thermal-stress terms at a structural discontinuity $\mathrm{C}_{3} \mathrm{E}_{\mathrm{ab}}\left|\alpha_{\mathrm{a}} \mathrm{T} a-\alpha_{\mathrm{b}} \mathrm{T}_{\mathrm{b}}\right|$ in Eq. (C10), $\mathrm{K}_{3} \mathrm{C}_{3} \mathrm{E}_{\mathrm{ab}}\left|\alpha_{\mathrm{a}} \mathrm{T} a-\alpha_{b} \mathrm{~T}_{\mathrm{b}}\right|$ in Eq. (Cll), and $\mathrm{C}_{3}^{\prime} E_{a b}\left|\alpha_{a} \mathrm{~T}_{a}-\alpha_{b} \mathrm{~T}_{b}\right|$ in Eq. (C13) will be dropped because the stress indices for lugs developed herein are not intended to apply if the lug is at a "gross discontinuity."

one other departure from current Code practice is also made by establishing criteria for evaluating the adequacy of the lug-pipe interface. This is accomplished by using the lower limit of 1.0 on $C_{T}, C_{L}$, and $C_{C}$ introduced in Section 2 and the alternate equations for stresses in the lug-pipe interface introduced in section 3 for shear and torsional moment loads. Since failure of the interface alone does not constitute failure of the pressure boundary, an aspect is introduced which is not specifically covered in $\mathrm{NB}-3600$, analysis of a zone which is not a pressure boundary but which is within the jurisdiction of NB-3600. Including these special limits for the lug-pipe interface in the manner described below effectively sets the stress limits for the interface just as if it were part of the pressure boundary, including addition of the stresses due to internal pressure, moment loads, and thermal gradient with those due to loads applied to the lug. 


\section{Satisfaction of Primary-Stress-Intensity Limit}

Primary-stress intensities in Class I piping systems are limited to $1.5 \mathrm{~S}_{\mathrm{m}}$ by Eq. (C9) (NB-3652). For points in the vicinity of integral lug attachments, modification of this equation is proposed by adding the term $\left(P_{L}+P_{b}\right)_{\text {lug }}$, which includes additional primary local membrane-stress intensities $\mathrm{P}_{\mathrm{L}}$ and additional primary bending-stress intensities $\mathrm{P}_{\mathrm{b}}$ caused by the presence of the lug. Thus

$$
B_{1} \frac{P D_{o}}{2 t}+B_{2} \frac{D_{o}}{2 I} M_{i}+\left(P_{L}+P_{b}\right)_{l u g} \leq 1.5 S_{m},
$$

where the indices $B_{1}$ and $B_{2}$ are those currently given in Table NB-3683.2-1, and the definition of $\left(P_{L}+P_{b}\right)_{l u g}$ in terms of appropriate $B_{l}$ indices is the subject of this section. It should be noted that the magnitude of the moment vector $\mathrm{M}_{i}$, as determined by an analysis of the piping system, would not be the same on the two sides of the lug, but in most cases the difference would be small. However, for cases where the difference is significant, the intent is to use the absolute mean value of the two. A footnote in the Code will be needed to cover this point.

Equation (C9) is now included as part of Paragraph NB-3652, "Consideration of Design Conditions." In USAS B31.7 (Ref. 13), the same equation was included in Paragraph 1-705.1, "Satisfaction of Primary Stress Intensity." The change in design concept implied by this change in the title of the heading is not trivial. If the force loads on lugs are not specified as design conditions in the Design Specification, these loads would not be included in the evaluation of Eq. (C9). If Eq. (C9) is to continue to be a valid check of primary-stress intensity, the design specification writer must be careful to include all sustained mechanical loads as design conditions. The present definition of $\mathrm{M}_{i}$ given in NB3652.2,

"M $M_{i}=$ Resultant moment loading due to loads caused by (1) weight, (2) earthquake, considering only one-half the range of the earthquake and excluding the effects of anchor displacement due to earthquake, and (3) other sustained design mechanical loads ...," 
is inadequate in this respect. It is recommended that the definition be changed to read as follows:

${ }^{\prime} M_{i}=$ Magnitude of the resultant moment due to loads caused by (1) weight, (2) earthquake, considering only one-half the range of the earthquake and excluding the effects of anchor displacement due to an earthquake, and (3) all other sustained mechanical loads ...."."

It appears appropriate to assume that most force loads such as weight. or earthquake inertial forces on lugs w1ll be "sustained" forces. The intent of $\mathrm{Eq}$. (Cy) is to l1m1t the stresses resulling frum such furces so that gross plastic deformations do not occur. A lower bound to this limit can be obtained by simply limiting the calculated elastic-membrane-stress intensity to the yield strength of the pipe material $\mathrm{S}_{\mathrm{y}}$, or $1.5 \mathrm{~S}$, since $\mathrm{S}_{\mathrm{m}}$ is essentially limited to $2 / 3 \mathrm{~S}_{\mathrm{y}}{ }^{*}$ For the six external loadings on lugs, this lower bound will actually be quite conservative, since in application the loadings causing the maximum stresses will be thrust $W$ and longitudinal and circumferential bending moments $\mathrm{M}_{L}$ and $\mathrm{M}_{C}$ respectively. These loadings produce mainly bending stresses, and for collapse to occur from bending stresses plastic hinges must be formed. A limit-load analysis could be used to establish a less-conservative lower bound. However, at present, no such analysis is available, and after formulating the analysis method a rather extensive parameter study would be required to establish appropriate $B$ indices.

Tables 6 to 8 of Section 2 show that the maximum membrane stresses caused by the loadings $W, M_{L}$, and $M_{C}$ are always substantially less than $2 / 3$ the maximum surface stresses (membrane-plus-bending stresses represented by the stress indices $C_{T}, C_{L}$, and $\left.C_{C} \geq 1.0\right)$. Limiting these stresses to $1.5 \mathrm{~s}_{\mathrm{y}}$ (where $\mathrm{s}_{\mathrm{y}}$ is the yield stress) thus automatically limits the maximum membrane stress intensities to less than $\mathrm{S}_{\mathrm{y}}$, or $1.5 \mathrm{~S}_{\mathrm{m}}$. Since the limit on Eq. (20) is $1.5 \mathrm{~S}_{\mathrm{m}}$ [the same as Eq. (C9)], an appropriate set

*For some austenitic steels and nonferritic materials, the value of $\mathrm{S}_{\mathrm{m}}$ may be up to 0.9 of the nominal yield strength. However, the strainhardening properties of these materials are generally assumed to be such that the value of $S_{m}$ is not greater than $2 / 3$ the effective yield strength. 
of $\mathrm{B}_{\ell}$ indices for use in the term $\left(\mathrm{P}_{\mathrm{L}}+\mathrm{P}_{\mathrm{b}}\right)_{\text {lug }}$ is simply

$$
\begin{aligned}
& \mathrm{B}_{\mathrm{T}_{1}}=(2 / 3) \mathrm{C}_{\mathrm{T}} \geq 2 / 3, \\
& \mathrm{~B}_{\mathrm{L}}=(2 / 3) \mathrm{C}_{\mathrm{L}} \geq 2 / 3, \\
& \mathrm{~B}_{\mathrm{C}}=(2 / 3) \mathrm{C}_{\mathrm{C}} \geq 2 / 3 .
\end{aligned}
$$

Membrane shear stresses were derived in Section 3 for the transverse shear loads $Q_{1}$ and $Q_{2}$ and the torsional moment load $M_{T}$. Since the membrane stress intensity from these loads is twice the maximum shear stress, $\mathrm{S}_{\mathrm{y}}$ (or $1.5 \mathrm{~S}_{\mathrm{m}}$ ) is an appropriate primary stress limit. Thus 2.0 times the right-hand side of Eqs. (13) and (14) and twice the greater of Eqs. (12) and (15) can be used directly in defining $\left(P_{I}+P_{b}\right)$ lug $\cdot$

The quantity $\left(P_{L}+P_{b}\right)$ lug to be added to the left side of Eq. (C9), including all six external loadings, is therefore

$$
\begin{aligned}
\left(P_{L}+P_{b}^{\prime}\right)_{\text {Iug }}=B_{T} \frac{W}{A_{\ell}}+B_{L} \frac{M_{L}}{Z_{\ell L}} & \\
& +B_{C} \frac{M_{C}}{Z_{\ell C}}+\frac{Q_{I}}{2 L_{I} I_{a}}+\frac{Q_{2}}{2 L_{2} I_{b}}+\bar{M}_{T},
\end{aligned}
$$

where, in order to cover the lug-pipe interface as well as the pipe wall, $I_{a}$ is taken as the smaller of $I_{2}$ and $t, I_{b}$ is the smaller of $I_{1}$ and $t$, and $\vec{M}_{T}$ is the greater of

$$
\bar{M}_{T_{p}}=\frac{M_{T}}{L_{c} L_{d}\left[1+\left(L_{c} / L_{d}\right)\right] t},
$$

and

$$
\bar{M}_{\mathrm{T} \ell}=\frac{2 \mathrm{M}_{\mathrm{T}}}{\left[1.57+0.093\left(\mathrm{~L}_{\mathrm{d}} / \mathrm{L}_{\mathrm{c}}\right)\right] \mathrm{L}_{\mathrm{c}}{ }^{2} \mathrm{~L}_{\mathrm{d}}} \text {, }
$$

where $L_{c}=\min \left(I_{1}, I_{2}\right)$ and $I_{d}=\max \left(I_{1}, I_{2}\right)$. In Eq. (21), the loading terms $W, M_{L}, M_{C}, Q_{1}, Q_{2}$, and $\bar{M}_{T}$ represent the absolute value of the sustained loading amplitudes and not the loading ranges. 
Satisfaction of Primary-Plus-Secondary

Stress-Intensity Range

Primary-plus-secondary stress intensities in Class I piping systems are limited to $S_{n} \leq 3 S_{m}$ by Eq. (ClO)(NB-3653.1). As discussed earlier, we propose to modify this equation by dropping the term $\mathrm{C}_{3} \mathrm{E}_{\mathrm{ab}} \mid \alpha_{\mathrm{a}} \mathrm{T}$ $\alpha_{b} T_{b} \mid$ and adding the term $\left(S_{n}\right)_{l u g}$; thus

$$
S_{n}=C_{1} \frac{P_{U}{ }^{D} U}{2 t}+C_{z} \frac{D_{U}}{2 I} M_{1}+\frac{1}{2(1-v)} \underline{\underline{E}} \alpha\left|\Delta T_{1}\right|+\left(S_{n}\right)_{1 u g} \leq 3 S_{m} .
$$

The stress indices $C_{T}, C_{L}$, and $C_{C}$ discussed in Section 2 for thrust $W$ and moment loadings $M_{L}$ and $M_{C}$ and twice the shear stresses $T_{1}, T_{2}$, and $\tau_{3}$ discussed in Section 3 are directly applicable in defining $\left(S_{n}\right)$ lug. However, even though $\tau_{1}, \tau_{2}$, and $\tau_{3}$ are the same as used in defining $\left(P_{L}+P_{b}\right)_{\text {lug }}$ above, the resulting stresses will not necessarily be the same because Eq. (C9) is in terms of sustained loading amplitudes whereas Eq. ( $\mathrm{ClO}$ ) is in terms of loading ranges. Additional internal-pressure stresses and thermal-gradient stresses due to the presence of the lug were classified as peak stresses in Sections 4 and 5 , and thus $\left(\mathrm{S}_{\mathrm{n}}\right)$ lug does not contain either a pressure term or a temperature term. Thus, for evaluating the stresses in a piping system at an integral lug, the quantity $\left(s_{n}\right)_{\text {lug }}$ to be added to $S_{n}$ is

$$
\left(S_{n}\right)_{\text {lug }}=C_{T} \frac{W^{*}}{A_{\ell}}+C_{L} \frac{M_{L}^{*}}{Z_{\ell L}}+C_{C} \frac{M_{C}^{*}}{Z_{\ell C}}+\frac{Q_{1}^{*}}{2 L_{1} I_{a}}+\frac{Q_{2}^{*}}{2 L_{2} I_{b}}+\bar{M}_{T}^{*}
$$

where $W^{*}, M_{C}^{*}, M_{L}^{*}, Q_{1}^{*}$, and $Q_{2}^{*}$ are the ranges of the loads and $\bar{M}_{T}^{*}$ is calculated using the range of $\overline{\mathrm{M}}_{\mathrm{T}}$.

\section{Satisfaction of Peak-Stress-Intensity Range}

Peak stress intensities in Class I piping systems are evaluated by Eq. (Cll) given in NB-3653.2. For the integral-lug problem this equation is to be modified by dropping the term $\mathrm{K}_{3} \mathrm{C}_{3} \mathrm{E}_{\mathrm{ab}}\left|\alpha_{\mathrm{a}} \mathrm{T}-\alpha_{\mathrm{b}} \mathrm{T}_{\mathrm{b}}\right|$ and adding 


$$
\begin{aligned}
& \left(s_{p}\right)_{\text {lug }}: \\
& S_{p}=K_{1} C_{1} \cdot \frac{P_{\circ} D_{0}}{2 t}+K_{2} C_{2} \frac{D_{\circ}}{2 I} M_{i} \\
& +\frac{1}{2(1-v)} K_{3} E \alpha\left|\Delta T_{1}\right|+\frac{1}{(I-v)} E \alpha\left|\Delta T_{2}\right|+\left(S_{p}\right)_{l u g},
\end{aligned}
$$

where the additament $\left(S_{p}\right)_{\text {lug }}$ will define the additional peak stresses caused by the presence of the lug for internal pressure in the pipe; thrust, shear, and/or moment loads on the lug; and a temperature gradient between the pipe and the lug.

The peak stress due to internal pressure was given in section 4 as $\mathrm{K}_{\ell \mathrm{p}} \mathrm{pD} / 2 \mathrm{t}$, with $\mathrm{K}_{\ell \mathrm{p}}=\mathrm{K}_{\ell}\left(1.5+0.537 \beta_{1} \beta_{2} \gamma\right)$. However, since Eq. (Cll) already has the internal pressure term $K_{1} C_{1}\left(P_{O} D_{0} / 2 t\right)$, which is retained in Eq. (24), and since $K_{1}=C_{1}=1.0$ for straight pipe remote from gross discontinuities, the internal pressure term for $\left(S_{p}\right)$ lug becomes

$$
\left[\left(K_{\ell}-1\right)\left(1.5+0.537 \beta_{1} \beta_{2} \gamma\right)\right] P_{0} D_{0} / 2 t
$$

Peak stresses due to thrust and moment loads on the lug are treated in the same manner as for the primary-plus-secondary stresses except that each of the indices $C_{T}, C_{L}$, and $C_{C}$ is to be multiplied by the index $K_{\ell}$. The thermal-stress term was defined by Eq. (19) in Section 5 as $\mathrm{K}_{\ell} \mathrm{E} \alpha\left|\mathrm{T}_{\ell}-\mathrm{T}_{\mathrm{W}}\right|$, and the local-peak-stress index $\mathrm{K}_{\ell}$ was defined in section 2 under the discussion on local stresses as 2.0 for as-welded fillet welds or 1.3 for ground fillet. welds.

The quantity $\left(S_{p}\right)_{\text {lug }}$ is thus defined as the sum of the individual loading terms:

$$
\begin{aligned}
&\left(\mathrm{S}_{\mathrm{p}}\right)_{\text {lug }}= {\left[\left(\mathrm{K}_{\ell}-1\right)\left(1.5+0.537 \beta_{1} \beta_{2} \gamma\right)\right] \frac{\mathrm{P}_{0} \mathrm{D}_{0}}{2 \mathrm{t}} } \\
&+\mathrm{K}_{\ell}\left[\mathrm{C}_{\mathrm{T}} \frac{\mathrm{W}^{*}}{\mathrm{~A}_{\ell}}+\mathrm{C}_{\mathrm{L}} \frac{\mathrm{M}_{\mathrm{L}}^{*}}{\mathrm{Z}_{\ell \mathrm{L}}}+\mathrm{C}_{\mathrm{C}} \frac{\mathrm{M}_{\mathrm{C}}^{*}}{\mathrm{Z}_{\ell \mathrm{C}}}+\frac{\mathrm{Q}_{1}^{*}}{2 \mathrm{~L}_{1} \mathrm{~L}_{\mathrm{a}}}+\frac{Q_{2}^{*}}{2 \mathrm{~L}_{2} \mathrm{I}_{\mathrm{b}}}+\bar{M}_{\mathrm{T}}^{*}\right] \\
& \quad+\mathrm{K}_{\ell} \mathrm{E \alpha}\left|\mathrm{T}_{\ell}-\mathrm{T}_{\mathrm{W}}\right| .
\end{aligned}
$$




\section{Simplified Elastic-Plastic Discontinuity Analysis}

If the piping system component fails to meet the $3 \mathrm{~S}_{\mathrm{m}}$ limit of Eq. (C10) [corresponding to Eq. (22) in the present context] for all pairs of load sets, the Code provides an alternate procedure for qualification under NB-3653.6 provided that the nominal value of the expansion stress intensity $\mathrm{S}_{\mathrm{e}}$ defined by Eq. (C12) is less than $3 \mathrm{~S}_{\mathrm{m}}$ and that the range of stress intensity defined by Eq. ( $\mathrm{Cl}_{3}$ ) is also less than $3 \mathrm{~S}_{\mathrm{m}}$. The procedure is to increase the alternating stress intensity $S_{a l t}$ for fatigue evaluation by the factor $\mathrm{K}_{\mathrm{e}} \geq 1.0$ prescribed by the Code under Eq. (C14). Equation ( $\mathrm{C} 12$ ) establishes a limit on thermal-expansion and anchormovement stresses with the intent of limiting the stress range to about the same magnitude as permitted in predecessor piping codes [e.g., ANSI B31.1.0]. ${ }^{14}$ Since these predecessor codes do not limit expansion stresses for pipe with lug attachments to a lower value than for pipe without lug attachments, there is no reason to change Eq. (C12) for a pipe with a lug. Equation ( $\mathrm{C} 13$ ) is intended to limit the possibility of ratchetting when $S_{n}$ exceeds $3 S_{m}$. The relatively conservative values recommended for the $B$ indices should give more than adequate protection against such a possibility. Accordingly, no addition to Eq. (C13) is considered necessary for lugs.

Equation (C14) does not require any changes, although, obviously, the numerical results will be influenced by the additional terms included in the evaluation of $S_{p}[$ Eqs. (24) and (25)]. For the analysis of lug attachments, however, it seems advisable to impose an additional constraint on the use of Eqs. ( $\mathrm{Cl} 4)$, etc., when the component f'ails to meet the $3 \mathrm{~s}_{\mathrm{m}}$ limit of Eq. (22). This is because loadings on the lugs caused by expansion of the piping system may add to the primary weight loads to give a total loading which is greater than the capacity of the lug for a single load application. For other piping components the stresses corresponding to the "constraint of free-end displacement" loads are categorized as $S_{n}$ stresses, which under the rules of NB-3653.6 have a very high absolute upper limit for small numbers of cycles. For example, the $S_{n}$ limit for type 304 stainless steel can be as high as 400,000 psi. While the fatigue 
limitation based on the peak stresses $S_{p}$ would probably prevent the majority of such conditions from occurring in practice, it is considered desirable to impose the additional limit for lugs:

$$
\left(\mathrm{S}_{\mathrm{n}}\right)_{\mathrm{lug}}^{* *}=\mathrm{C}_{\mathrm{T}} \frac{\mathrm{W}^{* *}}{\mathrm{~A}_{\ell}}+\mathrm{C}_{\mathrm{L}} \frac{\mathrm{M}_{\mathrm{L}}^{* *}}{\mathrm{Z}_{\ell \mathrm{L}}}+\mathrm{C}_{\mathrm{C}} \frac{\mathrm{M}_{\mathrm{C}}^{* *}}{\mathrm{Z}_{\ell \mathrm{C}}}+\frac{\mathrm{Q}_{1}^{* *}}{2 \mathrm{~L}_{1} \mathrm{~L}_{\mathrm{a}}}+\frac{\mathrm{Q}_{\mathrm{C}}^{* *}}{2 \mathrm{~L}_{2} \mathrm{I}_{\mathrm{b}}}+\bar{M}_{\mathrm{T}}^{* *} \leq 3 \mathrm{~S}_{\mathrm{m}},
$$

where the loads $\mathrm{W}^{* *}, \mathrm{M}_{\mathrm{L}}^{* *}, \ldots, \overline{\mathrm{M}}_{\mathrm{T}}^{* *}$ are defined as the maximum loads from any source.

\section{SUMMARY AND CONCLUSIONS}

A simplified design analysis procedure using stress indices has been developed for analyzing points in a Class I piping system where an integral lug attachment is welded to straight pipe. The procedure follows the general method outlined in Subsubarticle NB-3650 of the Code and is recommended for addition to the Code in a new paragraph, NB-3683.3, Indices for Integral Structural Attachments. The proposed wording for this paragraph is given as Appendix A. New terms (additaments) for addition to the Code equations when considering integral structural attachments have been developed. These additaments, defined herein as $\left(P_{L}+P_{b}\right)$ Iug' $\left(s_{n}\right)_{\text {lug' and }}\left(s_{p}\right)$ lug, are expressed in terms of internal pressure in the pipe, applied mechanical loads on the lug, the average temperatures of the lug and the pipe, and appropriate stress indices.

The stress indices developed in this report for the various loadings are based on available analytical solutions, some of which are more accurate than others. In each case, however, the results are believed to be conservative within the parameter ranges defined by the limits placed on the stress-index equations. For the cases of thrust and/or bending moments applied to the lugs, rather extensive comparisons between the stress-index analysis method developed here and two existing and widely used design analysis methods were made. These are the PW- 43 method $^{3}$ and the WRC-107 method. 4

A three-way comparison for thrust and moment loads among the stressindex analysis method, the WRC-107 method, and Ref. 2 calculations using 
Bijlaard's theoretical analysis indicates that the stress-index method is always conservative. The WRC-107 method tends to be conservative for loaded areas that are square and gives about the same results as the stress-index method. For loaded areas that are not square, the WRC-107 method is generally conservative for thrust loadings but less conservative than the stress-index method. For moment loadings, however, the WRC107 method tends to break down as the length-to-width (or width-to-length) ratio increases and apparently should not be used when this ratio exceeds 4 (or is 7 ess than $1 / 4)$,

Comparisons made between the stress-index method and the PW- 43 method, which limits the permissible thrust and longitudinal moment loads rather than the maximum stresses, indicate that the PW-43 method would result in higher stresses for thrust loads and lower stresses for longitudinal moment loads. For typical design conditions, indications are that the two methods would give comparable values for the permissible loads. The PW43 method does not consider circumferential moment loads.

The indices presented here for transverse shear and torsional moment loadings on the lug and for a temperature difference between the lug and the pipe are based on approximate analytical models which perhaps could be improved with further study. The indices, however, are believed to be conservative and adequate for piping-system design; and unless user experience indicates the need for more rigorous analyses, no further study is planned.

The indices developed for internal pressure loading are based on an analysis of a cylindrical shell with a solid circular insert. For lugs that are square or rectangular, approximations are introduced which should give conservative results; however, further study is needed to verify this point.

Finally, it should be pointed out that the stress-index-analysis method presented here for lugs is both simple to use and at least as accurate as any other known method. For those loadings where the accuracy can be questioned, the conservative practice of adding maximum stress intensities, even though these maximums may not occur at the same point or be oriented in the same direction, should provide adequate protection to the design. 


\section{ACKNOWLEDGMENTS}

The authors wish to thank the members of Task Group I of the Pressure Vessel Research Committee, Subcommittee for Piping, Pumps, and Valves, and the members of the ASME Boiler and Pressure Vessel Code Committee, Subgroup on Piping (SGD)(SC III), for their review and valuable suggestions.

\section{REFERENCES}

1. ASME boiler and Pressure Vessel Code, Section III, Nuclear Power Plant Components, American Society of Mechanical Engineers, New York, 1971.

2. W. G. Dodge, Secondary Stress Indices for Integral Structural Attachments to Straight Pipe, ORNL-TM-3476 (June 1973).

3. ASME Boiler and Pressure Vessel Code, Section I, Power Boilers, American Society of Mechanical Engineers, New York, 1970.

4. K. R. Wichman, A. D. Hopper, and J. I. Mershon, Local Stresses in Spherical and Cylindrical Shells Due to External Loadings, Welding Besearch Council Bulletin No. 107, August 1965.

5. R. F. Melworm and I. Berman, "Welded Attachments to Tubes - Experimentation, Analysis, and Design," Welding J. Res. Suppl. 45(10), 45464 (1966).

6. P. P. Bijlaard, "Stresses from Local Loadings in Cylindrical Pressure Vessels," Trans. ASME $17(6)$, 805-16 (1955).

\%. P. P. Bijlaard, "Stresses from Radial Loads and External Moments in Cylindrical Pressure Vessels," Welding J. Res. Suppl. 34(12), 608-17 (1955).

8. E. C. Rodabaugh, W. G. Dodge, and S. E. Moore, Stress Indices for Girth-Welded Joints, Including the Effects of Radial Weld Shrinkage, Mismatch, and Tapered-Wall Transitions, ORNL-TM-3643 (to be published).

9. S. TImoshenko and J. N. Goodier, 'l'heory of Elasticity, 2d Ed., pp. 275-78, McGraw-Hill, New York, 1951.

10. Peter Van Dyke, "Stresses in a Cylindrical Shell with a Rigid Inclusion," AIAA J. $\underline{3}(1)$, 125-37 (January 1967).

11. J. N. Goodier, "Thermal Stresses and Defurmution," J. Appl. Mech. 24 , 467-74 (September 1957). 
12. R. J. Roark (Ed.), Formulas for Stress and Strain, 4th Ed., p. 375, McGraw-Hill, New York, 1967.

13. USA Standard Code for Pressure Piping, Nuclear Power Piping, USAS B31.7-1969, American Society of Mechanical Engineers, New York, 1969.

14. Power Piping, USAS B31.1.0, Sect. 1 of the American Standard Code for Pressure Piping, American Society of Mechanical Engineers, New. York, 1967. 
Appendix A

\section{RECOMMENDED ADDITION TO ASME CODE SECTION III \\ TO COVER STRAIGHT PIPE WITH INTEGRAL \\ STRUCTURAL ATTACHMETTS}

The recommended addition to the ASME Boiler Code, Section III, consists of a new paragraph, NB-3683.3, to read as follows:

\section{NB-3683.3 STRESS INDICES FOR INTEGRAL STRUCTURAL ATTACHMENTS}

\section{(a) Limitations to Applicability of Indices}

(1) The attachment is welded to the pipe with a complete-penetration weld.

(2) The attachment material, weld material, and pipe material have essentially the same moduli of elasticity and coefficients of thermal expansion.

(3) $\beta_{1} \leq 0.5, \beta_{2} \leq 0.5$, and the product $\beta_{1} \times \beta_{2} \leq 0.075$, where $\beta_{1}$ and $\beta_{2}$ are defined in (c).

(4) The attachment is made on straight pipe, with the nearest edge of the attachment weld located at a minimum distance of $\sqrt{r t}$ from any other weld or other discontinuity; $r$ and $t$ are defined in (c).

(5) $D_{0} / t \leq 100$

(b) Equations To Be Satisfied

For points on a piping system with integral structural attachments, the term $C_{3} E_{a b}\left|\alpha_{a} T_{a}-\alpha_{b} T_{b}\right|$ shall be deleted from Eqs. (10), (11), and (13). Equations (9), (10), and (11) shall use the B, C, and $K$ indices given in l'able NB-3683.2-1 for "straight pipe, remote from welds or other discontinuities" and shall include the following additional terms [see also Footnote (1)]. Symbols are defined in (c).

\footnotetext{
${ }^{1}$ The value of $M_{i}$, under equilibrium conditions, is not identical on the two sides of the attachment when $M_{L}$ or $M_{C}$ is applied to the lug. Usually the change in $M_{i}$ will be negligible; if it is significant, however, the mean value is to be used in Eqs. (9) to (11).
} 
Equation (9), add to left-hand side:

$\left(P_{L}+P_{b}\right)_{\ell}=B_{T} W / A_{\ell}+B_{L} M_{L} / Z_{\ell L}+B_{C} M_{C} / Z_{\ell C}+Q_{1} / 2 L_{1} L_{a}+Q_{2} / 2 L_{2} I_{b}+\bar{M}_{T}$.

Equation (10), add to $S_{n}$ :

$S_{n \ell}=C_{T} W^{*} / A_{\ell}+C_{L} M_{L}^{*} / Z_{\ell L}+C_{C} M_{C}^{*} / Z_{\ell C}+Q_{1}^{*} / 2 L_{1} L_{a}+Q_{2}^{*} / 2 L_{2} I_{b}+\bar{M}_{T}^{*} \cdot$

Equation ( 11 ), add to $\delta_{p}$ :

$\mathrm{S}_{\mathrm{p} \ell}=\left[\left(\mathrm{K}_{\ell}-1\right)\left(1.5+0.537 \beta_{1} \beta_{2} \gamma\right)\right] \frac{\mathrm{P}_{\mathrm{o}} \mathrm{D}}{2 \mathrm{t}}+\mathrm{K}_{\ell}\left[\mathrm{S}_{\mathrm{n} \ell}\right]+\mathrm{K}_{\ell} \mathrm{E} \alpha\left|\mathrm{T}_{\ell}-\mathrm{T}_{\mathrm{w}}\right|$.

The following equation must also be satisfied:

$\mathrm{S}_{\mathrm{n} \ell}^{* *}=\mathrm{C}_{\mathrm{T}} \mathrm{W}^{* *} / \mathrm{A}_{\ell}+\mathrm{C}_{\mathrm{L}} \mathrm{M}_{\mathrm{L}}^{* *} / \mathrm{Z}_{\ell L}+\mathrm{C}_{C_{C}} \mathrm{M}_{\mathrm{C}}^{* *} / \mathrm{Z}_{\ell \mathrm{C}}$

$$
+Q_{1}^{X * *} / 2 I_{1} \ddot{L}_{a}+Q_{2}^{* *} / 2 I_{2} L_{b}+\bar{M}_{T}^{* *} \leq 3 S_{m}
$$

The value of $S_{m}$ shall be the lesser of that for the pipe material or of that for the lug material.

(c) Definitions (see also Fig. NB-3683.3; Fig. A.I herein)

$r=$ mean pipe radius (in.)

$t=$ nominal pipe-wall thickness (in.)

$\gamma=r / t$

$\beta_{1}=L_{1} / r$

$\beta_{2}=I_{2} / r$

$\mathrm{L}_{1}$ and $\mathrm{L}_{2}$ are defined in Fig. NB-3683.3

$I_{a}=$ Lesser of $L_{2}$ and $t$

$L_{b}=$ lesser of $L_{1}$ and $t$

$L_{c}=$ lesser of $L_{1}$ and $L_{2}$

$\mathrm{L}_{\mathrm{d}}=$ greater of $\mathrm{L}_{1}$ and $\mathrm{L}_{2}$

$C_{\mathrm{T}}=7.64(\gamma)^{1.64} \beta_{1} \beta_{2} \eta^{1.54} \geq 1.0$

$C_{L}=0.51(\gamma)^{1.74} \beta_{1} \beta_{2}{ }^{2} \eta^{4.74} \geq 1.0$

$\mathrm{C}_{\mathrm{C}}=0.76(\gamma)^{1.90} \mathrm{~B}_{1}{ }^{2} \beta_{2} \eta^{3.40} \geq 1.0$

$\eta=-\left(X_{1} \cos \theta+Y_{1} \sin \theta\right)-\frac{1}{A_{0}}\left(X_{1} \sin \theta-Y_{1} \cos \theta\right)^{2}$ 

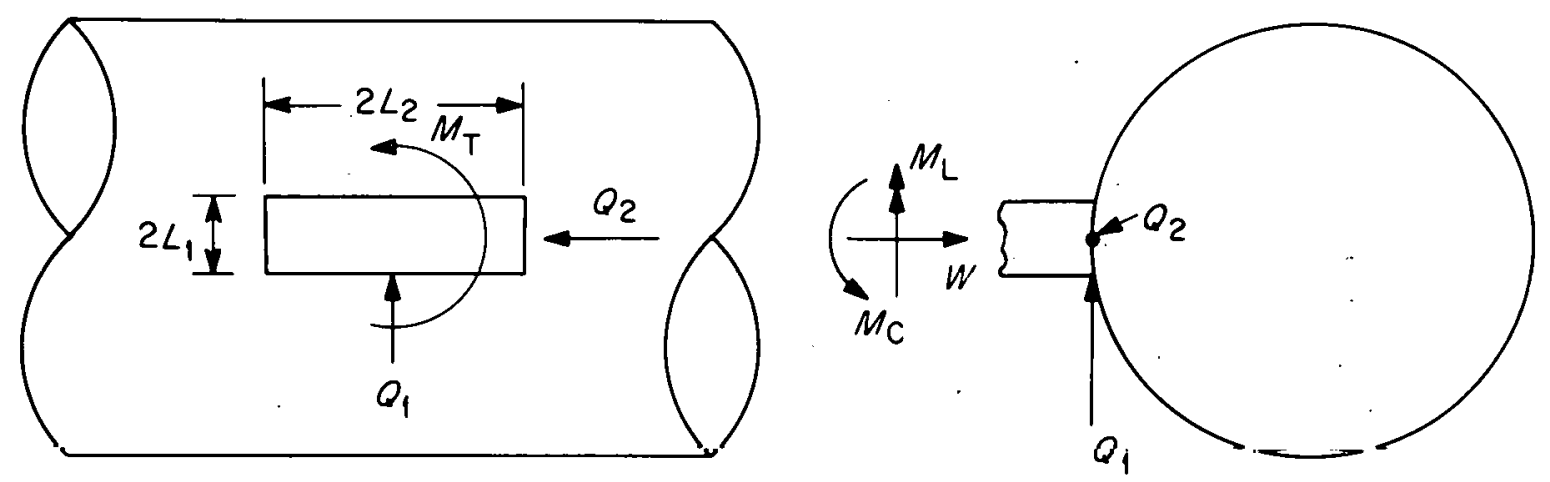

(a) Graphic representation of $L_{1}, L_{2}, W, M_{L}, Q_{1}, Q_{2}$, and $M_{T} ; I_{1}$ and $L_{2}$ are to be measured along the surface of the run pipe. Welds or fillet radii between attachment and pipe are not to be included.

ORNL - DWG $73-6629$
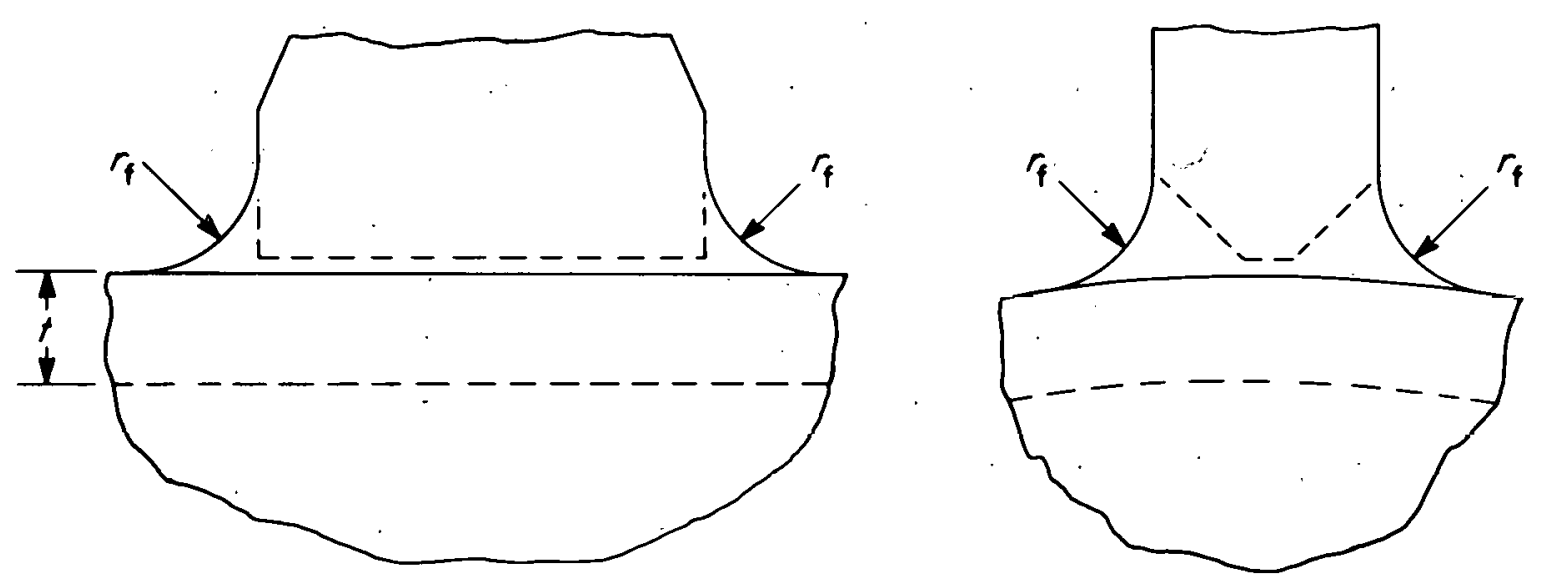

$$
r_{f} \geq t
$$

(b) Ground weld or integrally cast attachment; $\mathrm{K}_{\ell}=1.3$. For as-welded or fillet radii $r_{f} z t$, use $k_{l}=2.0$.

Fig. A.1. Proposed additional Code illustration entitled "Figure NB-3683.3: Nomenclature Illustration." 


$$
\begin{aligned}
& X_{1}=X_{0}+\log _{10} \beta_{1} \\
& Y_{1}=Y_{0}+\log _{10} \beta_{2}
\end{aligned}
$$

\begin{tabular}{lcccc}
\multicolumn{1}{c}{ Load } & $\mathrm{A}_{\mathrm{O}}$ & $\theta$ & $\mathrm{X}_{\mathrm{O}}$ & \multicolumn{1}{c}{$\mathrm{Y}_{\mathrm{O}}$} \\
\hline Thrust & 2.2 & $40^{\circ}$ & 0 & 0.05 \\
Longitudinal moment & 2.0 & $50^{\circ}$ & -0.45 & -0.55 \\
Circumferential moment & 1.8 & $40^{\circ}$ & -0.75 & -0.60
\end{tabular}

$R_{T}=(2 / 3) C_{T}, B_{L}=(2 / 3) C_{L}, B_{C^{-1}}=(2 / 3) C_{C}$

$A_{l}=4 I_{1} L_{2}\left(\right.$ in. $\left.{ }^{2}\right)$

$Z_{l L}=1 / I_{1} I_{2}{ }^{2} / 3\left(\right.$ in. $\left.{ }^{3}\right)$

$\mathrm{Z}_{\ell \mathrm{C}}=4 \mathrm{~L}_{1}{ }^{2} \mathrm{~L}_{2} / 3\left(\right.$ in. $\left.^{3}\right)$

$\mathrm{K}_{\ell}=2.0$ for "as-welded" fillet welds

$\mathrm{K}_{\ell}=1.3$ for "ground" fillet welds per Fig. NB-3683.3

$W, M_{L}, M_{C}, Q_{1}, Q_{2}$, and $M_{T}$ are absolute values of the sustained load amplitudes as shown in Fig. NB-3683.3. These are loads caused by (1) weight, (2) earthquake, considering only one-half the range of the earthquake and excluding the effects of anchor displacement due to earthquake, and (3) all other sustained mechanical lna.d.s. Units: $W, Q_{1}$, and $Q_{2}$ : $1 b ; M_{L}, M_{C}$, and $\bar{M}_{T}$ : in. $-1 . b$ $W^{*}, M_{L}^{*}, M_{C}^{*}, Q_{11}^{*}, Q_{e}^{*}$, and $M_{T}^{*}$ are ranges of loadings due to (1) thermal expansion, (2) anchor movements from any cause, (3) earthquake effects, and (4) all other mechanical loads which go through a range of magnitude

$W^{* *}, M_{L}^{* *}, M_{C}^{* *}, Q_{I}^{* *}, Q_{C}^{* *}$, and $\bar{M}_{T}^{* *}$ are absolute values of maximum loads from any cause

$\overline{\mathrm{M}}_{\mathrm{T}}=$ greater of $\mathrm{M}_{\mathrm{T}} /\left\{\mathrm{L}_{\mathrm{c}} \mathrm{L}_{\mathrm{d}}\left[1+\left(\mathrm{L}_{\mathrm{c}} / \mathrm{L}_{\mathrm{d}}\right)\right]\right\}$ and $\mathrm{M}_{\mathrm{T}} /[0.8+$ $\left.0.05\left(\mathrm{~L}_{\mathrm{d}} / \mathrm{L}_{\mathrm{c}}\right)\right] \mathrm{L}_{\mathrm{c}}{ }^{2} \mathrm{I}_{\mathrm{d}}$

$\bar{M}_{T}^{*}=$ same as $\bar{M}_{T}$, except use the loading range $M_{T}^{*}$

$\mathrm{T}_{\ell}=$ average temperature of that portion of the lug within a distance of $2 t$ from the surface of the pipe $\left({ }^{\circ} \mathrm{F}\right)$

$\mathrm{T}_{\mathrm{W}}=$ average temperature of the portion of the pipe under the lug and within a distance of $\sqrt{r t}$ from the edge of the lug $\left({ }^{\circ} \mathrm{F}\right)$ 
$\mathrm{E} \alpha=$ modulus of elasticity $(\mathrm{E})$ times the mean coefficient of thermal expansion $(\alpha)$, both at room temperature $\left(\mathrm{psi} /{ }^{\circ} \mathrm{F}\right)$

$\mathrm{P}_{0}$ = range of operating pressure ( $\left.p s i\right)$

$D_{0}=$ outside diameter of pipe (in.) 


\section{Appendix B \\ DIRECTIONS AND LOCATIONS OF MAXIMUM STRESSES \\ FOR THRUST AND MOMENT LOADINGS}

The stress indices developed in Section 2 for thrust and bending moment loads $\mathrm{W}, \mathrm{M}_{\mathrm{L}}$, and $\mathrm{M}_{\mathrm{C}}$ were based on the maximum surface stresses (membrane plus bending) calculated for the region of the pipe near the pipelug interface. Figure B.I shows the region of the pipe-lug intersection and the points at which stresses were calculated. Positions (1) and (2) on the edges of the lug are the locations at which the maximum stress occurred most often. Stresses were calculated using the computer program LUGS (Ref. '2) at each point in the rectangular array, starting at the center of the lug and extending a distance along the pipe of $X=x / L_{2}=$ 2 or 3 and a distance around the pipe of $\theta=\phi / \beta_{1}=2$ or 3 , depending on the width and length parameters $\beta_{1}$ and $\beta_{2}$ of the particular lug as shown below:

$$
\begin{array}{lll}
\text { For } \beta_{1} \leq 0.05 ; & 0 \leq \theta \leq 3.0 ; & \Delta \theta=0.25 \\
\text { For } \beta_{1} \geq 0.1 ; & 0 \leq A \leq 2.0 ; & \Delta A=0.1667 \\
\text { For } \beta_{2} \leq 0.1 ; & 0 \leq X \leq 3.0 ; & \Delta X=0.25 \\
\text { For } \beta_{2} \geq 0.2 ; & 0 \leq X \leq 2.0 ; & \Delta X=0.1667
\end{array}
$$

Stresses inside the loaded area (underneath the lug) were calculated but not used in establishing the stress indices. Because of symmetry, the stresses were evaluated for only one quadrant.

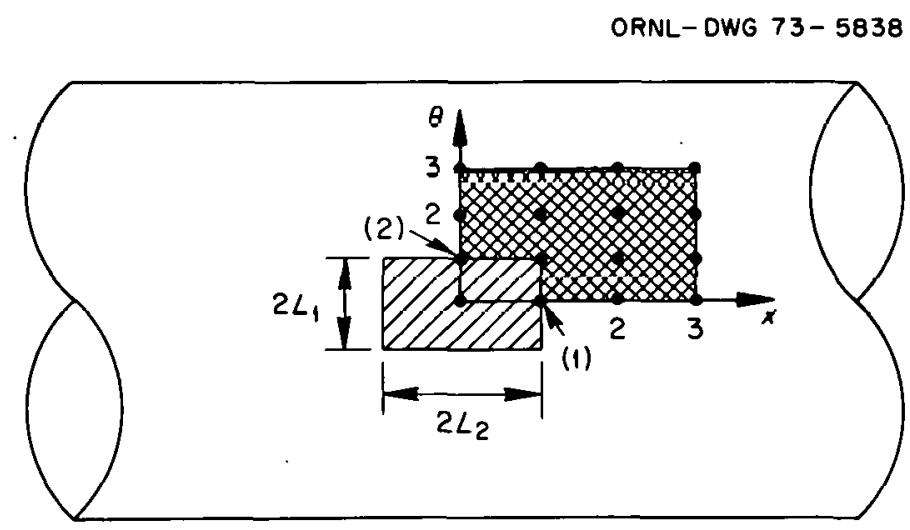

Fig. B.1. Region of the pipe-lug intersection used in calculating stresses. 
The maximum stresses reported here are the result of a rather extenSive parameter study for lug-pipe intersection dimensions within the parameter range $0.05 \leq \beta_{1} \leq 0.5 ; 0.05 \leq \beta_{2} \leq 0.5 ;$ and $\gamma=r / t=5,10,20$, 40, and 80. The locations and directions of the maximum surface stresses (membrane plus bending) for the three loadings $W, M_{L}$, and $\mathrm{M}_{C}$ are tabulated as functions of $\beta_{1}$ and $\beta_{2}$ in Tables B.l to B.5 for $\gamma$ values of $5,10,20$, 40, and 80 respectively. The direction is indicated as either " $\mathrm{C}$ " or "L" for circumferential or longitudinal under the columns labeled $D$. The coordinates of the maximum stress location are indicated by the pair of numbers under the columns " $X$ " and " $\theta$," except when the maximum occurred at positions (1) and (2) shown in Fig. B.I, in which case a (1) or (2) appears under the column labeled "X." In all but the five cases marked, the maximum stress was a compressive stress on the outside surface; and for all but three cases, the maximum "surface stress was the maximum stress intensity.

Tables B.6 to B.10 give the directions and locations of the maximum membrane stresses for $\gamma=r / t=5,10,20,40$, and 80, respectively, using the same format as used for the surface stresses. For moment loadings $\mathrm{M}_{\mathrm{L}}$ and $\mathrm{M}_{\mathrm{C}}$, there were a number of cases where the maximum membrane stress was apparently located outside the area used in the calculations. These are indicated by " $3+$ " in the appropriate columns. 
Table B.1. Direction and location of maximum surface stresses for pipe radiusto-thickness ratio of 5

\begin{tabular}{|c|c|c|c|c|c|c|c|c|c|c|}
\hline \multirow{2}{*}{$\beta_{1}$} & \multirow{2}{*}{$\beta_{2}$} & \multicolumn{3}{|c|}{ W } & \multicolumn{3}{|c|}{$\mathrm{M}_{\mathrm{L}}$} & \multicolumn{3}{|c|}{${ }^{\mathrm{M}_{\mathrm{C}}}$} \\
\hline & & $n^{a}$ & $x^{b}$ & $\theta$ & $D^{a}$ & $x^{b}$ & $\theta$ & $D^{a}$ & $x^{b}$ & $\theta$ \\
\hline 0.05 & $\begin{array}{l}0.05 \\
0.10 \\
0.20 \\
0.30 \\
0.40 \\
0.50\end{array}$ & $\begin{array}{l}C \\
1\end{array}$ & $\begin{array}{l}(1) \\
(2)\end{array}$ & I & $\int_{C}^{L}$ & $\begin{array}{l}\text { (1) } \\
\mid \\
0.83\end{array}$ & $\begin{array}{c}\downarrow \\
1.00\end{array}$ & C' & $\underbrace{0}_{0.17}$ & $\begin{array}{l}1.25 \\
1.25 \\
1.25 \\
1.25 \\
1.50 \\
1.50\end{array}$ \\
\hline 0.10 & $\begin{array}{l}0.05 \\
0.10 \\
0.20 \\
0.30 \\
0.40\end{array}$ & & $\begin{array}{c}(1) \\
(1) \\
(2) \\
1\end{array}$ & & $\begin{array}{l}I \\
\downarrow \\
C \\
C\end{array}$ & (1) & & & (2) & \\
\hline 0.2 & $\begin{array}{l}0.05 \\
0.10 \\
0.20 \\
0.30\end{array}$ & & (1) & & L & $\begin{array}{c}1.23 \\
(1) \\
1\end{array}$ & 0 & & $\begin{array}{c}1.00 \\
(2)\end{array}$ & 0.83 \\
\hline 0.3 & $\begin{array}{l}0.05 \\
0.10 \\
0.20\end{array}$ & & & & & & & & & \\
\hline 0.4 & $\begin{array}{l}0.05 \\
0.10\end{array}$ & & & & & $\begin{array}{r}1.25 \\
(1)\end{array}$ & 0.17 & & 1.00 & 0.83 \\
\hline 0.5 & 0.05 & $\downarrow$ & & & $\mathrm{L}^{\mathrm{C}}$ & 1.25 & 0 & & 1 & $\downarrow$ \\
\hline
\end{tabular}

aircction of the maximum ourfacc otrcoo: $C$ indicatco circumferential and $L$ indicates longitudinal.

$\mathrm{b}_{\mathrm{A}}(1)$ or (2) under this column indicates that the location of the maximum stress corresponds to the positions shown in Fig. B.1.

'Inside surf'ace, positive sign. 
Table B.2. Direction and location of maximum surface stresses for pipe radiusto-thickness ratio of 10

\begin{tabular}{|c|c|c|c|c|c|c|c|c|c|c|}
\hline \multirow{2}{*}{$\beta_{1}$} & \multirow{2}{*}{$\beta_{2}$} & \multicolumn{3}{|c|}{ W } & \multicolumn{3}{|c|}{$\mathrm{M}_{\mathrm{L}}$} & \multicolumn{3}{|c|}{${ }^{M_{C}}$} \\
\hline & & $D^{a}$ & $x^{b}$ & $\theta$ & $D^{a}$ & $x^{b}$ & $\theta$ & $D^{a}$ & $x^{b}$ & $\theta$ \\
\hline 0.05 & $\begin{array}{l}0.05 \\
0.10 \\
0.20 \\
0.30 \\
0.40 \\
0.50\end{array}$ & $\begin{array}{l}\text { C } \\
1\end{array}$ & $\begin{array}{c}(1) \\
(\varepsilon) \\
1\end{array}$ & & $\begin{array}{l}\text { L } \\
\text { L } \\
\text { C } \\
1\end{array}$ & $\begin{array}{c}(1) \\
\downarrow \\
0.83\end{array}$ & $\left.\right|_{1.00}$ & $\begin{array}{l}c \\
1\end{array}$ & $\begin{array}{c}0 \\
1 \\
0.17\end{array}$ & $\begin{array}{l}1.25 \\
1.75\end{array}$ \\
\hline 0.10 & $\begin{array}{l}0.05 \\
0.10 \\
0.20 \\
0.30 \\
0.40\end{array}$ & & $\begin{array}{c}(1) \\
(1) \\
(2) \\
1\end{array}$ & & $\begin{array}{l}\text { L } \\
L \\
L \\
C \\
C\end{array}$ & (1) & 1 & & (2) & \\
\hline 0.2 & $\begin{array}{l}0.05 \\
0.10 \\
0.20 \\
0.30\end{array}$ & & (1) & & $\begin{array}{l}\text { L } \\
\text { L } \\
\text { L } \\
\text { C }\end{array}$ & $\begin{array}{r}1.25 \\
(1)\end{array}$ & $\begin{array}{l}0 \\
1\end{array}$ & & $\begin{array}{r}1.00 \\
(2) \\
(2) \\
(2)\end{array}$ & 0.83 \\
\hline 0.3 & $\begin{array}{l}0.05 \\
0.10 \\
0.20\end{array}$ & & & & $\begin{array}{l}\mathrm{I} \\
I\end{array}$ & & & & $\begin{array}{r}1.00 \\
(2) \\
(2)\end{array}$ & 0.83 \\
\hline 0.4 & $\begin{array}{l}0.05 \\
0.10\end{array}$ & & & & & & & & $\begin{array}{l}1.00 \\
1.00\end{array}$ & $\begin{array}{l}0.67 \\
0.83\end{array}$ \\
\hline 0.5 & 0.05 & $\downarrow$ & & & $\downarrow$ & $\sqrt{ }$ & & & 1.00 & 0.83 \\
\hline
\end{tabular}

airection of the maximum surface stress: C indicates circumferential and $I$ indicates longitudinal.

$\mathrm{b}_{\mathrm{A}}(1)$ or (2) under this column indicates that the location of the maximum stress corresponds to the positions shown in Fig. B.I. 
Table B.3. Direction and location of maximum surface stresses for pipe radiusto-thickness ratio of 20

\begin{tabular}{|c|c|c|c|c|c|c|c|c|c|c|}
\hline \multirow{2}{*}{$\beta_{1}$} & \multirow{2}{*}{$\beta_{2}$} & \multicolumn{3}{|c|}{ W } & \multicolumn{3}{|c|}{$\mathrm{M}_{L}$} & \multicolumn{3}{|c|}{$\mathrm{M}_{\mathrm{C}}$} \\
\hline & & $\overline{D^{a}}$ & $\mathrm{x}^{\mathrm{b}}$ & 0 & $D^{a}$ & $\mathrm{x}^{\mathrm{b}}$ & $\theta$ & $D^{a}$ & $\mathrm{x}^{\mathrm{b}}$ & $\theta$ \\
\hline 0.05 & $\begin{array}{l}0.05 \\
0.10 \\
0.20 \\
0.30 \\
0.40 \\
0.50\end{array}$ & $\because$ & $\begin{array}{c}\text { (1) } \\
\text { (2) } \\
\mid\end{array}$ & & $\begin{array}{l}I \\
L \\
r \\
i\end{array}$ & $\begin{array}{c}(1) \\
\left.\right|^{(1)} \\
0.67 \\
0.67\end{array}$ & $\left.\right|_{\substack{1.00 \\
1.00}}$ & ? & $\left.\right|_{0.17} ^{0}$ & $\begin{array}{l}1.25 \\
1.50 \\
1.50\end{array}$ \\
\hline 0.10 & $\begin{array}{l}0.05 \\
0.10 \\
0.20 \\
0.30 \\
0.40\end{array}$ & & $\begin{array}{l}(1) \\
(1) \\
(2) \\
(2) \\
(2)\end{array}$ & & $\begin{array}{l}\text { L } \\
\text { L } \\
C \\
C \\
C\end{array}$ & (1) & & & $\begin{array}{c}\text { (2) } \\
\text { । }\end{array}$ & \\
\hline 0.2 & $\begin{array}{l}0.05 \\
0.10 \\
0.20 \\
0.30\end{array}$ & & (1) & & $\begin{array}{l}L \\
L \\
L \\
C\end{array}$ & & & & $\begin{array}{r}1.00 \\
\left(\begin{array}{l}2 \\
2 \\
(2)\end{array}\right.\end{array}$ & 0.83 \\
\hline 0.3 & $\begin{array}{l}.0 .05 \\
0.10 \\
0.20\end{array}$ & & & & $\begin{array}{l}\mathrm{L} \\
1\end{array}$ & & & & $\begin{array}{r}1.00 \\
.(2) \\
(2)\end{array}$ & 0.83 \\
\hline 0.4 & $\begin{array}{l}0.05 \\
0.10\end{array}$ & & & & & $\begin{array}{r}1.25 \\
(1)\end{array}$ & 0 & & $\begin{array}{l}1.00 \\
1.00\end{array}$ & $\begin{array}{l}0.83 \\
0.83\end{array}$ \\
\hline 0.5 & 0.05 & $\downarrow$ & & & $\downarrow$ & 1.25 & 0.17 & & 1.00 & 0.83 \\
\hline
\end{tabular}

Dircction of the maximum ourface otrcoo: $\mathrm{C}$ indicated circum ferential and $L$ indicates longitudinal.

$\mathrm{b}_{\mathrm{A}}(1)$ or (2) under this column indicates that the location of the maximum stress corresponds to the positions shown in Fig. B.l. 
Table B.4. Direction and location of maximum surface stresses for pipe radiusto-thickness ratio of 40

\begin{tabular}{|c|c|c|c|c|c|c|c|c|c|c|}
\hline \multirow{2}{*}{$\beta_{1}$} & \multirow{2}{*}{$\beta_{2}$} & \multicolumn{3}{|c|}{ W } & \multicolumn{3}{|c|}{$\mathrm{M}_{\mathrm{L}}$} & \multicolumn{3}{|c|}{${ }^{M_{C}}$} \\
\hline & & $D^{a}$ & $x^{b}$ & $\theta$ & $D^{a}$ & $x^{b}$ & $\theta$ & $D^{a}$ & $x^{b}$ & $\theta$ \\
\hline 0.05 & $\begin{array}{l}0.05 \\
0.10 \\
0.20 \\
0.30 \\
0.40 \\
0.50\end{array}$ & $\begin{array}{l}c \\
1\end{array}$ & $\begin{array}{c}\text { (1) } \\
\text { (2) } \\
\end{array}$ & & $\begin{array}{l}\text { L } \\
\text { L } \\
\text { C } \\
\text { C } \\
\text { C } \\
\text { C }\end{array}$ & $\begin{array}{r}(1) \\
(1) \\
(1) \\
0.83 \\
0.67 \\
0.83\end{array}$ & $\begin{array}{l}1.00 \\
1.00 \\
1.00\end{array}$ & $\begin{array}{l}c \\
\text { c }\end{array}$ & $\begin{array}{c}0 \\
(2) \\
0 \\
0 \\
0 \\
0\end{array}$ & $\begin{array}{l}1.25 \\
1.25 \\
1.75 \\
1.25 \\
1.25\end{array}$ \\
\hline 0.10 & $\begin{array}{l}0.05 \\
0.10 \\
0.20 \\
0.30 \\
0.40\end{array}$ & & $\begin{array}{l}\text { (1) } \\
\text { (1) } \\
\text { (1) } \\
(2) \\
(2)\end{array}$ & & $\begin{array}{l}\text { L } \\
\text { L } \\
\text { C } \\
\text { C } \\
\text { C }\end{array}$ & (1) & 1 & & $\begin{array}{c}(2) \\
(2) \\
(2) \\
0 \\
(2)\end{array}$ & 1.17 \\
\hline 0.2 & $\begin{array}{l}0.05 \\
0.10 \\
0.20 \\
0.30\end{array}$ & & (1) & & $\begin{array}{l}\text { L } \\
\text { L } \\
\text { C } \\
\text { C }\end{array}$ & & & & $\begin{array}{r}1.00 \\
(2) \\
(2) \\
(2)\end{array}$ & 0.67 \\
\hline 0.3 & $\begin{array}{l}0.05 \\
0.10 \\
0.20\end{array}$ & & & & $\begin{array}{l}\text { L } \\
\text { L } \\
\text { C }\end{array}$ & $\begin{array}{r}1.00 \\
(1) \\
(1)\end{array}$ & 0.33 & & $\begin{array}{r}1.00 \\
1.00 \\
(2)\end{array}$ & $\begin{array}{l}0.67 \\
0.83\end{array}$ \\
\hline 0.4 & $\begin{array}{l}0.05 \\
0.10\end{array}$ & & & & $\begin{array}{l}\mathrm{L} \\
\mathrm{c}\end{array}$ & $\begin{array}{l}1.00 \\
1.00\end{array}$ & $\begin{array}{l}0.50 \\
0.17\end{array}$ & & $\begin{array}{l}1.00 \\
1.00\end{array}$ & $\begin{array}{l}0.67 \\
0.67\end{array}$ \\
\hline 0.5 & 0.05 & 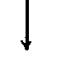 & 1 & & L & 1.00 & 0.05 & $\downarrow$ & 1.00 & 0.83 \\
\hline
\end{tabular}

Direction of the maximum surface stress: C indicates circumferential and $I$ indicates longitudinal.

$\mathrm{b}_{\mathrm{A}}$ (1) or (2) under this column indicates that the location of the maximum stress corresponds to the positions shown in Fig. B.I. ${ }^{C}$ Maximum stress intensity occurs on inside surface, $S_{L}=169.4$, $\mathrm{S}_{\mathrm{C}}=-20.69$. 
Table B.5. Direction and location of maximum surface stresses for pipe radiusto-thickness ratio of 80

\begin{tabular}{|c|c|c|c|c|c|c|c|c|c|c|}
\hline \multirow{2}{*}{$\beta_{1}$} & \multirow{2}{*}{$B_{2}$} & \multicolumn{3}{|c|}{ W } & \multicolumn{3}{|c|}{$\mathrm{M}_{\mathrm{L}}$} & \multicolumn{3}{|c|}{$\mathrm{M}_{\mathrm{C}}$} \\
\hline & & $D^{a}$ & $x^{b}$ & $\theta$ & $D^{a}$ & $x^{b}$ & $\theta$ & $D^{a}$ & $x^{b}$ & $\theta$ \\
\hline \multirow[t]{5}{*}{0.05} & 0.05 & C & (1) & & $\mathrm{L}$ & (I) & 1 & C & 0 & 1.25 \\
\hline & 0.10 & 1 & (2) & & C & 1 & & & $\begin{array}{l}\text { (2) } \\
0\end{array}$ & 1.50 \\
\hline & $\begin{array}{l}0.20 \\
0.30\end{array}$ & & & & 1 & & 1 & & $\begin{array}{c}0.17 \\
0\end{array}$ & $\begin{array}{l}1.00 \\
1.75\end{array}$ \\
\hline & 0.40 & & & & & 0.67 & 1.00 & & 0 & 1.75 \\
\hline & 0.50 & & \rfloor$. & & $J$ & 0.67 & 1.00 & & 0 & 1.75 \\
\hline \multirow[t]{4}{*}{0.10} & 0.05 & & (1) & & I & (1) & 1 & & (2) & \\
\hline & 0.10 & & & & $\begin{array}{l}\text { I } \\
\text { C }\end{array}$ & & & & & \\
\hline & 0.30 & & & & C & & & & $\downarrow$ & \\
\hline & 0.40 & & & & C & & & & 0 & $\overline{1} . \overline{1} 7$ \\
\hline \multirow[t]{3}{*}{0.2} & $\begin{array}{l}0.05 \\
0.10\end{array}$ & & & & $\begin{array}{l}\mathrm{L} \\
\mathrm{L}\end{array}$ & $\begin{array}{r}1.00 \\
(1)\end{array}$ & 0.33 & & $\begin{array}{r}1.00 \\
(2)\end{array}$ & 0.67 \\
\hline & 0.20 & & & & $\mathrm{C}$ & (1) & & & (2) & \\
\hline & 0.30 & & & & $\mathrm{C}$ & (1) & & & $(2)$ & \\
\hline \multirow[t]{3}{*}{0.3} & 0.05 & & & & L & 1.00 & 0.50 & & 1.00 & 0.67 \\
\hline & 0.10 & & & & c & (1) & & & 1.00 & 0.67 \\
\hline & 0.20 & & & & C & 1.00 & 0.50 & & (2) & \\
\hline \multirow[t]{2}{*}{0.4} & 0.05 & & & & C & $3+$ & 0 & & 1.00 & 0.67 \\
\hline & 0.10 & & & & $d$ & (I) & & & & \\
\hline 0.5 & 0.05 & \rfloor & $1 ., \cap 0$ & 0.33 & $c^{e}$ & $3+$ & 0 & & & \\
\hline
\end{tabular}

Direction of the maximum surt'ace stress: C indicates circumferential and $\mathrm{L}$ indicates longitudinal.

$\mathrm{b}_{\mathrm{A}}$ (1) or (2) under this column indicates that the location of the maximum stress corresponds to the positions shown in F'ig. B. 1 .

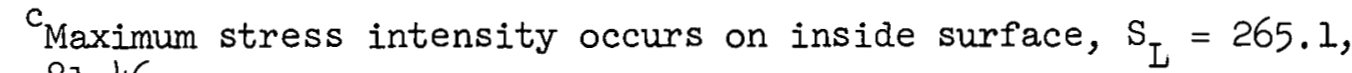
$\mathrm{s}_{\mathrm{C}}=-81.46$.

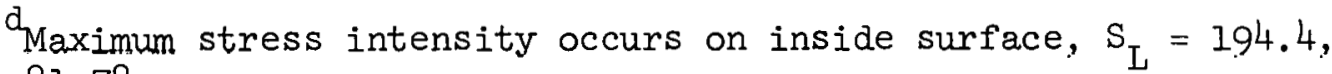
$\mathrm{S}_{\mathrm{C}}=-81.78$.

en inside surface. 
Table B.6. Direction and location of maximum membrane stresses for pipe radius-

to-thickness ratio of 5

\begin{tabular}{|c|c|c|c|c|c|c|c|c|c|c|}
\hline \multirow{2}{*}{$B_{1}$} & \multirow{2}{*}{$\beta_{2}$} & \multicolumn{3}{|c|}{ W } & \multicolumn{3}{|c|}{$\mathrm{M}_{\mathrm{L}}$} & \multicolumn{3}{|c|}{${ }^{\mathrm{M}_{\mathrm{C}}}$} \\
\hline & & $D^{a}$ & $x^{b}$ & $\theta$ & $D^{Q}$ & $x^{b}$ & $\theta$ & $D^{a}$ & $x^{b}$ & $\theta$ \\
\hline 0.05 & $\begin{array}{l}0.05 \\
0.10 \\
0.20 \\
0.30 \\
0.40 \\
0.50\end{array}$ & ${ }^{c}$ & $\begin{array}{c}(2) \\
\mid\end{array}$ & & I & $\begin{array}{c}3+ \\
3+ \\
1.17 \\
(1) \\
(1) \\
(1)\end{array}$ & $\begin{array}{l}0 \\
0 \\
0\end{array}$ & $\begin{array}{l}\mathrm{L} \\
1\end{array}$ & & $\begin{array}{r}3+ \\
1\end{array}$ \\
\hline 0.10 & $\begin{array}{l}0.05 \\
0.10 \\
0.20 \\
0.30 \\
0.40\end{array}$ & & & & & $\begin{array}{c}3+ \\
3+ \\
1.17 \\
(1) \\
(1)\end{array}$ & $\begin{array}{l}0 \\
0 \\
0\end{array}$ & & & \\
\hline 0.2 & $\begin{array}{l}0.05 \\
0.10 \\
0.20 \\
0.30\end{array}$ & 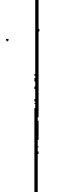 & $\begin{array}{l}(1) \\
(2) \\
(2) \\
(2)\end{array}$ & & & $\begin{array}{c}3+ \\
3+ \\
1.17 \\
(1)\end{array}$ & $\begin{array}{l}0 \\
0 \\
0\end{array}$ & & & \\
\hline 0.3 & $\begin{array}{l}0.05 \\
0.10 \\
0.20\end{array}$ & & $\begin{array}{l}(1) \\
(1) \\
(2)\end{array}$ & . & & $\begin{array}{c}3+ \\
3+ \\
1.33\end{array}$ & $\begin{array}{l}0 \\
0 \\
0\end{array}$ & & & $\begin{array}{l}1.67 \\
1.67 \\
1.67\end{array}$ \\
\hline 0.4 & $\begin{array}{l}0.05 \\
0.10\end{array}$ & & $\begin{array}{l}\text { (1) } \\
\text { (1) }\end{array}$ & & & $\begin{array}{l}3+ \\
3+\end{array}$ & $\begin{array}{l}0 \\
0\end{array}$ & & & $\begin{array}{l}1.33 \\
1.33\end{array}$ \\
\hline 0.5 & 0.05 & $\downarrow$ & (1) & $\downarrow$ & $\checkmark$ & $3+$ & 0 & $\nabla$ & $\downarrow$ & 1.17 \\
\hline
\end{tabular}

a Direction of the maximum surface stress:' C indicates circumferential and $L$ indicates longitudinal..

$\mathrm{b}_{\mathrm{A}}$ (1) or (2) under this column indicates that the location of the maximum stress corresponds to the positions.shown in Fig. B.l. 
Table B.7. Direction and location of maximum membrane stress for pipe radius-

to-thickness ratio of 10

\begin{tabular}{|c|c|c|c|c|c|c|c|c|c|c|}
\hline \multirow{2}{*}{$\beta_{1}$} & \multirow{2}{*}{$\mathrm{B}_{2}$} & \multicolumn{3}{|c|}{$W$} & \multicolumn{3}{|c|}{${ }^{\mathrm{M}_{\mathrm{L}}}$} & \multicolumn{3}{|c|}{${ }^{\mathrm{M}_{\mathrm{C}}}$} \\
\hline & & $D^{a}$ & $\bar{x}^{b}$ & $\dot{\theta}$ & $\dot{D}^{a}$ & $\dot{x}^{b}$ & $\theta$ & $D^{a}$ & $x^{b}$ & $\theta$ \\
\hline 0.05 & $\begin{array}{l}0.05 \\
0.10 \\
0.20 \\
0.30 \\
0.40 \\
0.50\end{array}$ & $\begin{array}{l}\mathrm{C} . \\
C \\
\mathrm{C} \\
\mathrm{C} \\
\mathrm{C} \\
\mathrm{L}\end{array}$ & $(\dot{z})$ & & $\stackrel{c}{c}$ & $\begin{array}{r}3+ \\
1.5 \\
(1) \\
(1) \\
(1) \\
(1)\end{array}$ & $\begin{array}{l}0 \\
0\end{array}$ & $\stackrel{L}{L}$ & $\begin{array}{l}0 \\
1\end{array}$ & $3+$ \\
\hline 0.10 & $\begin{array}{l}0.05 \\
0.10 \\
0.20 \\
0.30 \\
0.40\end{array}$ & i & & & & $\begin{array}{r}3+ \\
1.5 \\
(1) \\
(1) \\
(1)\end{array}$ & $\begin{array}{l}0 \\
0\end{array}$ & & & \\
\hline 0.2 & $\begin{array}{l}0.05 \\
0.10 \\
0.20 \\
0.30\end{array}$ & & $\begin{array}{l}(1) \\
(2) \\
(2) \\
(1)\end{array}$ & & & $\begin{array}{l}3+ \\
1.67 \\
(1) \\
(1)\end{array}$ & $\begin{array}{l}0 \\
0\end{array}$ & & . & $\begin{array}{c}1.67 \\
1.67 \\
1.83 \\
3+\end{array}$ \\
\hline 0.3 & $\begin{array}{l}0.05 \\
0.10 \\
0.20\end{array}$ & & $\begin{array}{l}\text { (1) } \\
\text { (1) } \\
(2)\end{array}$ & & & $\begin{array}{l}3+ \\
1.67 \\
(1)\end{array}$ & $\begin{array}{l}0 \\
0\end{array}$ & & $\downarrow$ & $\begin{array}{l}1.17 \\
1.17 \\
1.33\end{array}$ \\
\hline (1). 4 & $\begin{array}{l}0.05 \\
0.10\end{array}$ & & $\begin{array}{l}(1) \\
(1)\end{array}$ & & & $\begin{array}{c}3+ \\
1.83\end{array}$ & $\begin{array}{l}0 \\
0\end{array}$ & & $\begin{array}{l}(2) \\
(2)\end{array}$ & \\
\hline 0.5 & 0.05 & $\downarrow$ & (1) & & $\downarrow$ & $3+$ & $n$ & $\downarrow$ & (2) & \\
\hline
\end{tabular}

"Direction of the maximum surface stress: C indicates circumferential and $\mathrm{L}$ indicates longitudinal.

$\mathrm{b}_{\mathrm{A}}$ (1) or (2) under this column indicates that the location of the maximum stress corresponds to the positions shown in Fig. B.I. 
Table B.8. Direction and location of maximum membrane stress for pipe radiusto-thickness ratio of 20

\begin{tabular}{|c|c|c|c|c|c|c|c|c|c|c|}
\hline \multirow{2}{*}{$\beta_{1}$} & \multirow{2}{*}{$\beta_{2}$} & \multicolumn{3}{|c|}{$\mathrm{W}$} & \multicolumn{3}{|c|}{$\mathrm{M}_{\mathrm{L}}$} & \multicolumn{3}{|c|}{${ }^{M_{C}}$} \\
\hline & & $D^{a}$ & $x^{b}$ & $\theta$ & $D^{2}$ & $x^{b}$ & $\theta$ & $D^{a}$ & $x^{b}$ & $\theta$ \\
\hline 0.05 & $\begin{array}{l}0.05 \\
0.10 \\
0.20 \\
0.30 \\
0.40 \\
0.50\end{array}$ & $\begin{array}{l}C \\
C \\
\text { L } \\
\text { L } \\
\text { L } \\
\text { L }\end{array}$ & (2) & & $\begin{array}{l}\mathrm{C} \\
1\end{array}$ & $\begin{array}{l}2.00 \\
1.17 \\
1.00 \\
0.83 \\
0.67 \\
0.67\end{array}$ & $\begin{array}{c}0 \\
0 \\
0.83 \\
1.25 \\
1.00 \\
1.00\end{array}$ & $\begin{array}{l}\mathrm{L} \\
\mathrm{I}\end{array}$ & 0 & $\begin{array}{c}3+ \\
1\end{array}$ \\
\hline 0.10 & $\begin{array}{l}0.05 \\
0.10 \\
0.20 \\
0.30 \\
0.40\end{array}$ & $\begin{array}{l}\text { C } \\
\text { C } \\
\text { C } \\
\text { L } \\
\text { I }\end{array}$ & & & & $\begin{array}{l}2.00 \\
1.17 \\
(1) \\
0.67 \\
0.67\end{array}$ & $\begin{array}{c}0 \\
0 \\
1.00 \\
1.00\end{array}$ & & & \\
\hline 0.2 & $\begin{array}{l}0.05 \\
0.10 \\
0.20 \\
0.30\end{array}$ & $\begin{array}{l}C \\
C \\
C \\
L\end{array}$ & $\begin{array}{l}\text { (1) } \\
(2) \\
(2) \\
(2) .\end{array}$ & & & $\begin{array}{l}2.25 \\
1.33 \\
(1) \\
(1)\end{array}$ & $\begin{array}{l}0 \\
0\end{array}$ & & & $\begin{array}{l}1.33 \\
1.33 \\
1.50 \\
1.67\end{array}$ \\
\hline 0.3 & $\begin{array}{l}0.05 \\
0.10 \\
0.20\end{array}$ & $\begin{array}{l}C \\
C \\
L\end{array}$ & $\begin{array}{l}\text { (1) } \\
\text { (1) } \\
\text { (1) }\end{array}$ & & & $\begin{array}{l}2.50 \\
1.33 \\
(1)\end{array}$ & $\begin{array}{l}0 \\
0\end{array}$ & & $\begin{array}{c}(2) \\
(2) \\
0\end{array}$ & i. 17 \\
\hline 0.4 & $\begin{array}{l}0.05 \\
0.10\end{array}$ & $\begin{array}{l}\mathrm{C} \\
\mathrm{C}\end{array}$ & $\begin{array}{l}\text { (1) } \\
\text { (1) }\end{array}$ & & & $\begin{array}{l}2.75 \\
1.50\end{array}$ & $\begin{array}{l}0 \\
0\end{array}$ & & $\begin{array}{l}(2) \\
(2)\end{array}$ & \\
\hline 0.5 & 0.05 & $\mathrm{C}$ & (1) & & $\downarrow$ & 2.75 & 0 & 1 & 1.00 & 0.83 \\
\hline
\end{tabular}

Direction of the maximum surface stress: C indicates circumferential and $I$ indicates longitudinal.

${ }^{b} \mathrm{~A}$ (1) or (2) under this column indicates that the location of the maximum stress corresponds to the positions shown in Fig. B.l. 
Table B.9. Direction and location of maximum membrane stresses for pipe radiusto-thickness ratio of 40

\begin{tabular}{|c|c|c|c|c|c|c|c|c|c|c|}
\hline \multirow{2}{*}{$B_{1}$} & \multirow{2}{*}{$\beta_{2}$} & \multicolumn{3}{|c|}{ W } & \multicolumn{3}{|c|}{$\mathrm{M}_{\mathrm{L}}$} & \multicolumn{3}{|c|}{${ }^{M_{C}}$} \\
\hline & & $D^{\dot{d}}$ & $x^{\mathrm{V}}$ & $\theta$ & $D^{\ddot{a}}$ & $x^{b}$ & $\theta$ & $D^{d}$ & $x^{v}$ & $\theta$ \\
\hline 0.05 & $\begin{array}{l}0.05 \\
0.10 \\
0.20 \\
0.30 \\
0.40 \\
0.50\end{array}$ & $\begin{array}{l}C \\
C \\
\bar{L} \\
L \\
L \\
L\end{array}$ & $\begin{array}{l}(2) \\
.\end{array}$ & & $\begin{array}{l}\mathrm{C} \\
\mathrm{l}\end{array}$ & $\begin{array}{c}1.50 \\
(1) \\
0.67 \\
1\end{array}$ & $\begin{array}{c}0 \\
1.00 \\
1\end{array}$ & $\mathrm{~L}^{\mathrm{L}}$ & $\begin{array}{r}0 \\
.\end{array}$ & $3^{3+}$ \\
\hline 0.10 & $\begin{array}{l}0.05 \\
0.10 \\
0.20 \\
0.30 \\
0.40\end{array}$ & $\begin{array}{l}\text { C } \\
C \\
L \\
L \\
L \\
L\end{array}$ & & & & $\begin{array}{r}1.50 \\
(1) \\
(1) \\
0.67 \\
0.67\end{array}$ & $\begin{array}{c}0 \\
1.00 \\
1.00\end{array}$ & & & $\begin{array}{c}1.67 \\
1.83 \\
2+ \\
2+ \\
2+\end{array}$ \\
\hline 0.2 & $\begin{array}{l}0.05 \\
0.10 \\
0.20 \\
0.30\end{array}$ & $\begin{array}{l}C \\
L \\
L \\
L\end{array}$ & (I) & & & $\begin{array}{r}1.50 \\
1.17 \\
(1) \\
(1)\end{array}$ & $\begin{array}{l}0 \\
0\end{array}$ & & $\begin{array}{c}(2) \\
(2) \\
0 \\
0\end{array}$ & $\begin{array}{l}1.17 \\
1.13\end{array}$ \\
\hline 0.3 & $\begin{array}{l}0.05 \\
0.10 \\
0.20\end{array}$ & $\begin{array}{l}\text { C } \\
\text { L } \\
\text { L }\end{array}$ & & & & $\begin{array}{r}2.00 \\
1.17 \\
(1)\end{array}$ & $\begin{array}{l}0 \\
0\end{array}$ & & $\begin{array}{l}(2) \\
(2) \\
(2)\end{array}$ & \\
\hline 0.4 & $\begin{array}{l}0.05 \\
0.10\end{array}$ & $\begin{array}{l}\mathrm{C} \\
\mathrm{L}\end{array}$ & & & & $\begin{array}{l}2.00 \\
1.17\end{array}$ & $\begin{array}{l}0 \\
0\end{array}$ & & $\begin{array}{r}1.00 \\
(2)\end{array}$ & 0.83 \\
\hline 0.5 & 0.05 & $\mathrm{C}$ & $\downarrow$ & 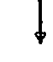 & $\downarrow$ & 2.00 & 0 & ! & 1.00 & 0.83 \\
\hline
\end{tabular}

airection of the maximum surface stress: C indicates circumferential and $L$ indicates longitudinal.

$\mathrm{b}_{\mathrm{A}}(1)$ or (2) under this column indicates that the location of the maximum stress corresponds to the positions shown in Fig. B.1. 
Table B.10. Direction and location of maximum membrane stresses for pipe radius-. to-thickness ratio of 80

\begin{tabular}{|c|c|c|c|c|c|c|c|c|c|c|}
\hline \multirow{2}{*}{$\beta_{1}$} & \multirow{2}{*}{$\beta_{2}$} & \multicolumn{3}{|c|}{$\mathrm{W}$} & \multicolumn{3}{|c|}{$M_{L}$} & \multicolumn{3}{|c|}{${ }^{\mathrm{M}_{\mathrm{C}}}$} \\
\hline & & $D^{a}$ & $x^{b}$ & $\dot{\theta}$ & $D^{a}$ & $x^{b}$ & $\theta$ & $D^{a}$ & $x^{b}$ & $\theta$ \\
\hline 0.05 & $\begin{array}{l}0.05 \\
0.10 \\
0.20 \\
0.30 \\
0.40 \\
0.50\end{array}$ & L & $\begin{array}{r}(1) \\
(2) \\
1\end{array}$ & & $\begin{array}{l}C \\
\text { C } \\
C \\
C \\
L \\
L\end{array}$ & $\begin{array}{r}1.25 \\
(1) \\
0.67 \\
1\end{array}$ & $\begin{array}{c}0 \\
1.00 \\
1\end{array}$ & $\begin{array}{l}\mathrm{L} \\
1\end{array}$ & $\begin{array}{l}0 \\
1\end{array}$ & $\begin{array}{c}2.25 \\
2.50 \\
3+ \\
\downarrow\end{array}$ \\
\hline 0.10 & $\begin{array}{l}0.05 \\
0.10 \\
0.20 \\
0.30 \\
0.40\end{array}$ & & $\begin{array}{l}(1) \\
(1) \\
(2) \\
(2) \\
(2)\end{array}$ & & $\begin{array}{l}\mathrm{C} \\
\mathrm{C} \\
\mathrm{C} \\
\mathrm{C} \\
\mathrm{L}\end{array}$ & $\begin{array}{r}1.25 \\
(1) \\
(1) \\
0.67 \\
(1)\end{array}$ & $\begin{array}{c}0 \\
1.00\end{array}$ & & & $\begin{array}{c}1.33 \\
1.33 \\
1.67 \\
2.00 \\
2+\end{array}$ \\
\hline 0.2 & $\begin{array}{l}0.05 \\
0.10 \\
0.20 \\
0.30\end{array}$ & , & (1) & & $\begin{array}{l}\mathrm{C} \\
\mathrm{d}\end{array}$ & $\begin{array}{r}1.50 \\
(1) \\
(1) \\
(1)\end{array}$ & 0 & & $\begin{array}{c}(2) \\
(2) \\
(2) \\
0\end{array}$ & 1.17 \\
\hline 0.3 & $\begin{array}{l}0.05 \\
0.10 \\
0.20\end{array}$ & & & & & $\begin{array}{r}1.50 \\
(1) \\
(1)\end{array}$ & 0 & & $\begin{array}{r}1.00 \\
(2) \\
(2)\end{array}$ & 0.83 \\
\hline 0.4 & $\begin{array}{l}0.05 \\
0.10\end{array}$ & & & & & $\begin{array}{l}3+ \\
(1)\end{array}$ & 0 & & $\begin{array}{l}1.00 \\
1.00\end{array}$ & $\begin{array}{l}0.67 \\
0.67\end{array}$ \\
\hline 0.5 & 0.05 & $\downarrow$ & & & $\downarrow$ & $3+$ & 0 & & 1.00 & 0.67 \\
\hline
\end{tabular}

airection of the maximum surface stress: C indicates circumferential and $L$ indicates longitudinal.

${ }^{b_{A}}$ (1) or (2) under this column indicates that the location of the maximum stress corresponds to the positions shown in Fig. B.l. 
Appendix C

EXAMPIE ANALYSIS OF A LUG SUPPORT

\section{Loads and Primary-Stress-Intensity Limit}

The determination of the loads applied to the lugs is not a subject of this report. However, the engineering judgment involved in determining the loads can be as significant as the accuracy of the equations relating loads to. stresses developed herein. This aspert san be illustrated by analyzing a 24-in. sched-16n vertinal pipe ( $\mathrm{n}_{0}=24$ in., $t$ 2.343 in.) supported by lugs as shown in Fig. C. 7 , with the size of the

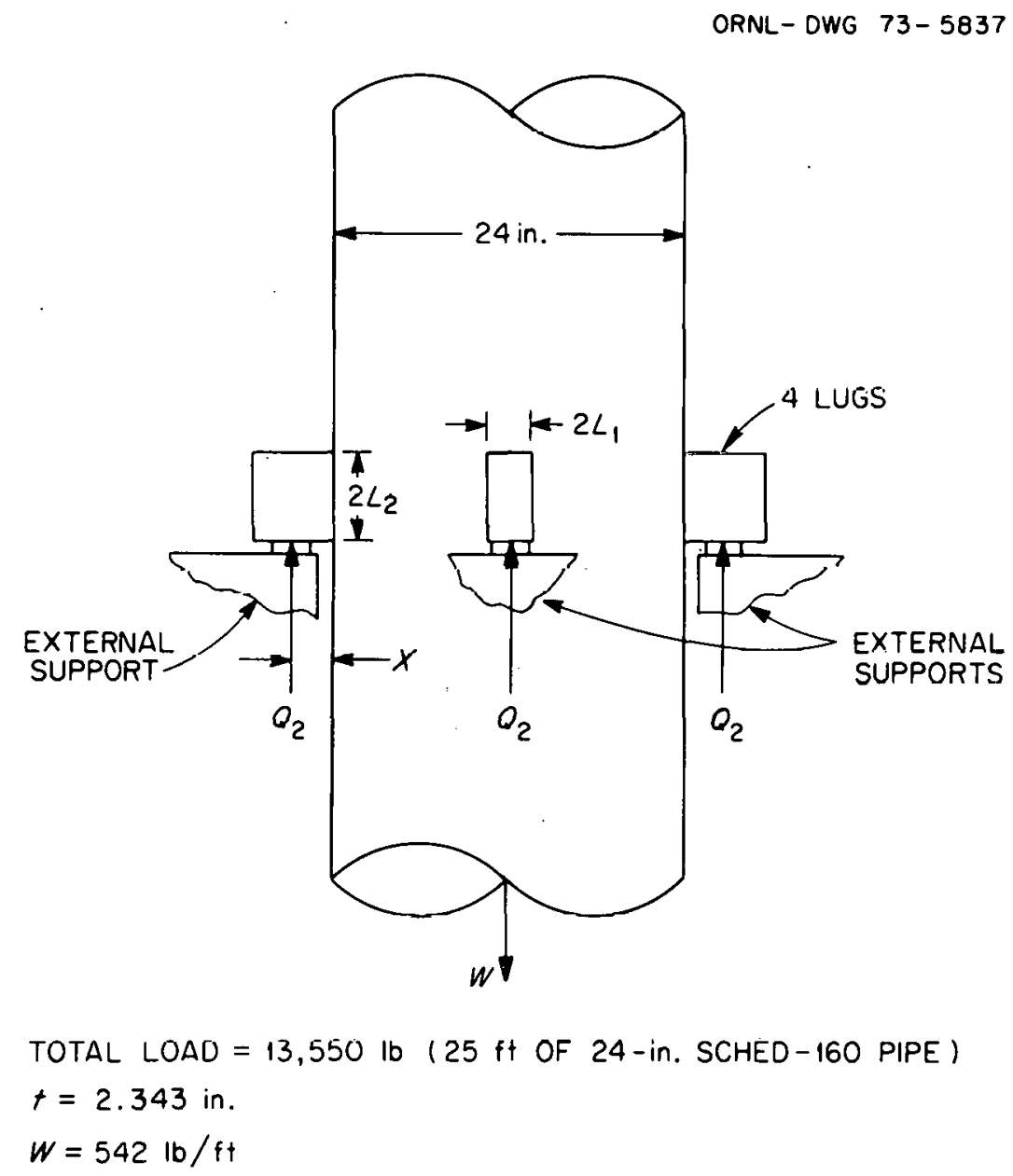

Fig. C.l. Example of lugs used to support vertical pipe. 
lug to be controlled by the modified primary-stress-intensity limit equation given in Table 2 of the text:*

$$
B_{1} \frac{P D_{o}}{2 t}+B_{2} \frac{D_{o}}{2 I} M_{i}+\left(P_{L}+\cdot P_{b}\right)_{1 u g} \div 1.5 S_{m}
$$

where, from Eq. (21) of the text,

$$
\left(P_{L}+P_{b}\right)_{\text {lug }}=\frac{B_{T} W}{A_{\ell}}+\frac{B_{L} M_{L}}{Z_{\ell L}}+\frac{B_{C} M_{C}}{Z_{l C}}+\frac{Q_{1}}{2 L_{1} L_{a}}+\frac{Q_{2}}{2 L_{2} L_{b}}+\bar{M}_{T}
$$

We will assume that the primary stress intensity in the pipe without considering the lug supports is $20,000 \mathrm{psi}$ : Specifically, $\mathrm{PD}_{\mathrm{o}} / 2 \mathrm{t}$ is assumed to be $20,000 \mathrm{psi}$, and the magnitude $D_{0} \mathrm{M}_{i} / 2 \mathrm{I}$ is assumed to be 10,000 psi.** The stress indices $B_{1}=0.5$ and $B_{2}=1.0$ are the values given in Table NB-3683.2-1 of the Code for straight pipe remote from welds or other discontinuities. Thus,

$$
B_{1} \frac{P D_{O}}{2 t}+B_{2} \frac{D_{0}}{2 I} M_{i}=20,000 \mathrm{psi}
$$

It is also assumed that the four support-reaction forces $Q_{2}$ act at some offset distance $X$ from the pipe surface as shown in Fig. C.1. The longitudinal moment $M_{L}$ acting on the pipe is then

$$
M_{L}=Q_{2} X \text {. }
$$

Assume further that

$$
\begin{aligned}
& 1.5 \mathrm{~S}_{\mathrm{m}}=30,000 \mathrm{psi}, \\
& \mathrm{W}=\mathrm{M}_{\mathrm{C}}=Q_{1}=\bar{M}_{\mathrm{T}}=0, \\
& \mathrm{~L}_{1}=\mathrm{L}_{2} / 2 .
\end{aligned}
$$

*Equations numbered C.1, C.2, etc., in this appendix are not to be confused with equations abstracted from the Code and given similar numbers in the main text.

** It should be noted that $M_{i}$ used in Code Eqs. (9) and (13) is a magnitude of a moment vector, whereas $M_{i}$ used in Code Eqs. (1U), (11), and (12) is a range of a moment vector. These do not necessarily have the same numerical value. 
The section modulus of the lug is therefore

$$
Z_{l L}=2 / 3 L_{2}^{3}
$$

The equation for determining the lug dimension $\mathrm{L}_{2}$ from Eqs. (C.I), (C.2), and (C.3) is then

$$
\left(P_{L}+P_{h}\right)_{1 u g}=\frac{3 B_{L} Q_{2} X}{c^{\prime} L_{2}{ }^{0}}+\frac{Q_{2}}{2 \bar{L}_{2} L_{b}}=10,000 \mathrm{psi}
$$

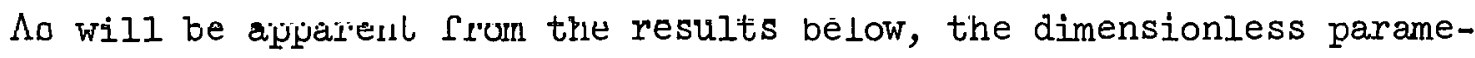
ters involved in this example (i.e., $\gamma=4.62, B_{1} \leq 0.093, B_{i}<0.186$ ) are such that $C_{L}$ is controlled by the lower limit of $1.0, B_{I}=2 / 3$ (see Table 4 in the text), and $I_{b}=L_{1}$ (because $L_{1}$ is less than $t$ ). Hence, Eq. (C.7) for determining $\mathrm{L}_{2}$ becomes

$$
\left(P_{L}+P_{b}\right)_{\operatorname{lug}}=\frac{Q_{2} X}{L_{2}{ }^{3}}+\frac{Q_{2}}{L_{2}{ }^{2}}=10,000 \mathrm{psi} .
$$

The question arises as to what should be used for $Q_{2}$ and $X$. If an ideal situation is assumed in which each lug takes one-quarter of the total load and the load is introduced adjacent to the pipe surface, then $Q_{2}=13,550 / 4, X=0, L_{2}=0.582$ in., and the minimum size of the lug is 0.582 by 1.164 in. However, unless some carefully designed spring supports are used, it is more likely that, at some time, the entire load will be taken by one lug. It might be possible to design supports under the lug liat would introduce the load quite close to the pipe wall, perhaps making $X$ as little as 0.5 in. Table $C .1$ shows various lug sizer requircd for various values of $X$ if all the load (13,550 lb) is supported ky one lug.

However, if the analyst had assumed the ideal conditions of $Q_{2}=$ $13,550 / 4$ and $X=0$, if he had specified a lug with $2 \mathrm{~L}_{2}=1.164$ and $2 \mathrm{~L}_{1}=$ 0.582 , if all of the load were then inadvertently taken by one of the four lugs, and if the supports were such that $X$ was effectively 2 in., then

$$
\left(P_{L}+P_{b}\right)_{\text {lug }}=\frac{(13,550)(2)}{(0.582)^{3}}+\frac{(13,550)}{(0.582)^{2}}=144,470 \mathrm{psi} .
$$

In this case the support might fail. 
Table C.1. Minimum lug dimensions for support of the 24-in. sched-160 pipe

\begin{tabular}{ccccccccc}
\hline $\mathrm{X}$ & $\mathrm{I}_{2}$ & $\begin{array}{c}\text { Stress }^{\mathrm{b}} \\
\text { due to } \\
\text { bending } \\
\text { (psi) }\end{array}$ & $\begin{array}{l}\text { Stress } \\
\text { due to } \\
\text { shearing } \\
\text { (psi) }\end{array}$ & $\begin{array}{l}\text { Lug size } \\
\text { (in.) }\end{array}$ & $\frac{2 \mathrm{~L}_{2}}{\text { in. })}$ & $2 \mathrm{~L}_{1}$ & $\beta_{2}$ & $\beta_{1}$ \\
\hline 0 & 1.16 & 0 & 10,000 & 2.32 & 1.16 & 0.107 & 0.054 \\
0.5 & 1.36 & 2693 & 7,325 & 2.72 & 1.36 & 0.126 & 0.063 \\
1.0 & 1.50 & 4014 & 6,022 & 3.00 & 1.50 & 0.139 & 0.069 \\
2.0 & 1.71 & 5419 & 4,633 & 3.42 & 1.71 & 0.158 & 0.079 \\
4.0 & 2.01 & 6674 & 3,354 & 4.02 & 2.01 & 0.186 & 0.093 \\
\hline
\end{tabular}

$a_{\text {Total load }}=13,550 \mathrm{lb}(25 \mathrm{ft}$ at $542 \mathrm{lb} / \mathrm{ft})$.

$\mathrm{b}_{\text {Bending stress }}=\mathrm{Q}_{2} \mathrm{X} / \mathrm{L}_{2}{ }^{3}$.

${ }^{c}$ Shearing stress $=Q_{2} / L_{2}{ }^{2}$.

If the pipe used in the above example had been a 24-in. sched-40 pipe $(t=0.687$ in., $r=11.656$ in., $w=542 \mathrm{lb} / \mathrm{ft}$ ) rather than a sched -160 pipe, it would not have been possible to establish the value of the stress index $B_{L}$ without evaluating $C_{L}$ for specific lug dimensions as prescribed in Appendix A; that is,

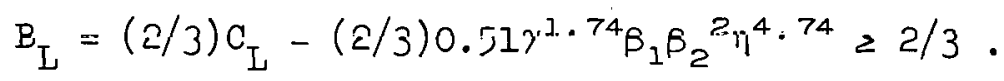

This makes determining the minimum lug size more complex, and a trial-anderror solution is indicated. For this purpose a rather simple timesharing computer program in the BASIC language was used.* The results are given in Table C.2. It is interesting to note that for the smaller lug sizes, when $X \leq 0.5$, the stresses in the lug control the design (i.e., $\left.B_{L}=2 / 3\right)$, whereas for the larger sizes the stresses in the pipe are controlling.

*The program listing is given at the end of this appendix. 
Table C.2. Minimum lug dimensions for support of the 24-in. sched-40 pipe ${ }^{a}$

\begin{tabular}{lccccc}
\hline $\mathrm{X}$ & $\begin{array}{l}\text { Stress } \\
\text { due to } \\
\text { bending }\end{array}$ & $\begin{array}{c}\text { Stress } \\
\text { due to } \\
\text { shearing }\end{array}$ & $2 \mathrm{~L}_{1}$ & $2 \mathrm{~L}_{2}$ & $\mathrm{~B}_{\mathrm{L}}$ \\
\hline 0 & 0 & 10,000 & 0.65 & 1.31 & $2 / 3$ \\
0.5 & 3765 & 6,235 & 0.83 & 1.66 & $2 / 3$ \\
1.0 & 5932 & 4,467 & 0.98 & 1.96 & 0.810 \\
2.0 & 7569 & 2,431 & 1.33 & 2.66 & 1.385 \\
4.0 & 8482 & 1,518 & 2.02 & 4.04 & 2.731 \\
\hline & $a_{\mathrm{n}_{n}}=24$ in, $t=0.687$ in., $r-11.656$ in.;
\end{tabular}

total load $=427 \mathrm{C}^{\prime} \mathrm{Ib}(25 \mathrm{ft}$ at $171.1 \mathrm{lb} / \mathrm{ft})$.

$\mathrm{b}_{\text {Bending stress }}=\mathrm{Q}_{2} \mathrm{X} / \mathrm{L}_{2}{ }^{3}$.
${ }^{\mathrm{c}}$ Shearing stress $=\mathrm{Q}_{2} / \mathrm{L}_{2}{ }^{2}$.

Assumed Operating Conditions and Pipe Properties

The example analysis for the sched-160 pipe is continued below to illustrate the use of the remainder of the equations given in Appendix A.

A very simple set of operating conditions will be assumed, consisting of 50 cycles during which:

$\frac{P_{O} D_{0}}{2 t}$ varies from 0 to 16,000 psi to 0 ,

$\frac{D_{0}}{2 I} M_{i}$ varies from 0 to 8000 psi to 0 ,

$\frac{1}{2(1-\nu)} E \alpha\left|\Delta \overline{\mathrm{T}}_{1}\right|$ varies from 0 to $18,000 \mathrm{psi}$ to 0 ,

$\frac{1}{1-v} E \alpha\left|\Delta \mathrm{T}_{2}\right|$ varies from 0 to $9000 \mathrm{psi}$ to 0 ,

$\mathrm{E} \alpha\left|\mathrm{T}_{\ell}-\mathrm{T}_{\mathrm{W}}\right|$ varies from 0 to $15,000 \mathrm{psi}$ to 0 ,

the thermal expansion of the piping system is such that the tensile stress in the pipe below the lugs varies from 0 to 500 psi to 0 . 
The conservative assumptions are made that the entire load will be taken by one lug and that $X=2.0$ in. From Table C.l the minimum lug dimensions required to satisfy the primary-stress-intensity limit are $2 \mathrm{~L}_{2}=3.42 \mathrm{in}$. and $2 \mathrm{~L}_{1}=1.71 \mathrm{in}$.

The pipe cross section is assumed to be circular within a tolerance of $0.08 \mathrm{t}$, so that $\mathrm{K}_{1}=1.00$. The pipe material is assumed to be an austenitic stainless steel with an allowable stress intensity $S_{m}$ of 20,000 psi at the maximum operating temperature, and the weld between the lug and pipe is assumed to be ground to a radius as required by Fig. A.1. Hence $\mathrm{K}_{\ell}=1.3$.

\section{Primary-Plus-Secondary Stress-Intensity Range Limit}

Following the procedure outlined in Appendix A $[\mathrm{NB}-3683.3(\mathrm{~b})]$, the limiting equation for satisfaction of the allowable primary-plus-secondary stress-intensity range is

$$
S_{n}=C_{1} \frac{P D_{0}}{2 t}+C_{2} \frac{D_{0}}{2 I} M_{i}+\frac{1}{2(1-v)} E \alpha\left|\Delta T_{1}\right|+S_{n \ell} \leq 3 S_{m} \cdot \text { (C.10) }
$$

With the assumed operating conditions and with $C_{1}=C_{2}=1.0$, the numerical value of $\mathrm{S}_{\mathrm{n}}$ is

$$
s_{n}=16,000+8,000+18,000+s_{n \ell}=42,000+s_{n \ell},
$$

where $S_{n l}$ is calculated using the range of loads $M_{L}^{*}$ and $Q_{2}^{*}$ operating on the lugs:

$$
S_{n \ell}=C_{T_{1}} \frac{M_{L}^{*}}{Z_{\ell L}}+\frac{Q_{2}^{*}}{2 T_{1_{2} T_{b}}}=C_{T_{1}} \frac{Q_{2}^{*} X}{Z_{\ell L}}+\frac{Q_{2}^{*}}{2 T_{1_{2}} T_{b}}
$$

The range $Q_{2}^{*}$ is obtained by multiplying the axial stress in the pipe, assumed here to be $500 \mathrm{psi}$, by the cross-sectional metal area of the pipe $\left(159.4 \mathrm{in.}^{2}\right)$, or $Q_{2}^{*}=79,700 \mathrm{lb}$. The numerical value of $S_{n l}$ is thus

$$
\mathrm{s}_{\mathrm{n} \ell}=(1.0) \frac{(79,700)(2)}{(1.333)(0.855)(1.71)^{2}}+\frac{79,700}{(2)(1.71)(0.855)}=75,090 \mathrm{psi} \text {, }
$$


and

$$
\mathrm{S}_{\mathrm{n}}=42,000+75,090=117,090 \mathrm{psi} \text {. }
$$

which is well above the $3 \mathrm{~S}_{\mathrm{m}}$ limit of 60,000 psi.

The lug design might still be acceptable provided that the restriction placed on the maximum load stresses $\mathrm{S}_{\mathrm{n} \ell}^{* *} \leq 3 \mathrm{~S}_{\mathrm{m}}$ [see Appendix A, NB3683.2(b); also Eq. (26) of the text] is met and the design is qualified under the simplified elastic-plastic discontinuity analysis procedures of NB-3653.6 as modified in Appendix A. For this particular design the maximum load stress condition is

$$
\mathrm{S}_{\mathrm{n} \ell}^{* *}=\mathrm{C}_{\mathrm{L}} \frac{\mathrm{M}_{\mathrm{L}}^{* *}}{\mathrm{Z}_{\ell, \mathrm{L}}}+\frac{\mathrm{Q}_{2}^{* *}}{2 \mathrm{~L}_{2} \mathrm{~L}_{\mathrm{b}}}=3 \mathrm{~S}_{\mathrm{m}},
$$

where $M_{L}^{* *}=Q_{2}^{* *} X$, and the maximum load $Q_{2}^{* *}$ is equal to the range $Q_{2}^{*}$ plus the deadweight $\mathrm{W}$; that is,

$$
Q_{2}^{* *}=79,700+13,550=93,250 \text {. }
$$

Thus,

$$
\begin{aligned}
S_{11 \ell}^{* *}=(1) \frac{(93,250)(2)}{(1.333)(0.855)(1.71)^{2}} & \\
& +\frac{93,250}{(2)(1.71)(0.855)}=87,850 \mathrm{psi},
\end{aligned}
$$

which is greater than $3 \mathrm{~S}_{\mathrm{m}}=60,000 \mathrm{psi}$. Therefore the design is unacceptable. In order to pass this restriction, the tensile stress in the pipe would need to be equal to or less than $315 \mathrm{psi}$, rather than $50 \mathrm{c}$ psi as assumed.

\section{Simplified Elastic-Plastic Discontinuity Analycic [NB-3653.6]}

Even though the design failed to pass the maximum-load stress condition $\mathrm{S}_{\mathrm{n} l}^{* *} \leq 3 \mathrm{~S}_{\mathrm{m}}$, the example is continued to show that the potentially overloaded condition is not necessarily prevented by the fatigue analysis. 
In order to qualify the design under Paragraph NB-3653.6 of the Code, two conditional equations must first be satisfied; that is, Code Eqs. (12) and (13). (Paragraph NB-3653.2, Satisfaction of Peak Stress Intensity Range, was ruled out since $S_{n}=117,090>3 S_{m}$.) Code $E q$. (12) for the expansion stress $\mathrm{S}_{\mathrm{e}}$ is (see Table 2 of the text):

$$
S_{e}=C_{2} \frac{D_{0}}{2 I} M_{i}^{*} \leq 3 S_{m}
$$

where the magnitude of $D_{0} / 2 I M_{i}^{*}$ was postulated to be 10,000 psi. With $\mathrm{C}_{2}=1.0$, the expansion stress limit Eq. (C.15) is obviously met.

The other conditional equation [Code Eq. (13), Table 1 of the text] was modified for the analysis of lug supports in that the term involving $\left|\alpha_{a} T_{a}-\alpha_{b} T_{b}\right|$ was dropped. Thus the appropriate limit is

$$
C_{1} \frac{P_{o} D_{0}}{2 t}+C_{2} \frac{D_{O} M_{i}}{2 I} \leq 3 S_{m}
$$

where $P_{0}$ is the range of operating pressure and $M_{i}$ is the magnitude of the moment vector used in the primary-stress-intensity limit check. Accordingly, with $\mathrm{C}_{1}=1.0, \mathrm{P}_{0} \mathrm{D}_{0} / 2 \mathrm{t}=16,000 \mathrm{psi}$, and $\mathrm{D}_{\mathrm{O}} \mathrm{M}_{\mathrm{i}} / 2 \mathrm{I}=10,000 \mathrm{psi}$ the left-hand side of the above equation is $26,000 \mathrm{psi}$. This value is less than $3 S_{m}=60,000 \mathrm{psi}$; hence, Code Eq. (13) is also satisfied.

We may thus proceed to evaluate the alternating stress

$$
S_{\text {alt }}=K_{e} \frac{S_{p}}{2}
$$

using the modified equation for $S_{p}$ given in Appendix A $[N B-3683.3(b)]$ and $\mathrm{K}_{\mathrm{e}}$ calculated according to the rules of NB-3653.6(c). The peak-stress intensity range is

$$
\begin{aligned}
S_{p}=K_{1} C_{1} \frac{P_{0} D_{0}}{2 t}+K_{2} C_{2} \frac{D_{0}}{2 I} M_{i}+\frac{1}{2(1-v)} & K_{3} E \alpha\left|\Delta T_{1}\right| \\
& +\frac{1}{1-\nu} E \alpha\left|\Delta T_{2}\right|+S_{p l},
\end{aligned}
$$


and, with $K_{1}=K_{2}=K_{3}=1.0$, we get

$$
s_{p}=16,000+8,000+18,000+9,000+s_{p l}=51,000+S_{p l} \cdot
$$

Since

$$
\begin{aligned}
\mathrm{S}_{\mathrm{p} \ell} & =\left[\left(\mathrm{K}_{\ell}-1\right)\left(1.5+0.537 \beta_{1} \beta_{2} \gamma\right)\right] \frac{\mathrm{P}_{\mathrm{o}} \mathrm{O}_{\mathrm{o}}}{2 t}+\mathrm{K}_{\ell}\left(\mathrm{S}_{\mathrm{n} \ell}\right)+\mathrm{K}_{\ell} \mathrm{E \alpha}\left|\mathrm{T}_{\ell}-\mathrm{T}_{\mathrm{w}}\right| \\
& =[(1.3-1 .)(1.5+0.03 .1)] \times 1.6,000+1.3[75,090]+1.3 \times 15,000 \\
& =7,350+97,620+19,500=124,470,
\end{aligned}
$$

therefore

$$
S_{p}=51,000+124,470=175,470 .
$$

For austenitic stainless steel with material parameters $\mathrm{m}=1.7$ and $\mathrm{n}=0.3$ from Paragraph NB-3228.3(b) and with $\mathrm{S}_{\mathrm{n}} \geq 3 \mathrm{mS}$, that is,

$$
s_{n}=117, n, 0,>(3)(1.7)(2 n, n n n)=1 n 2, n n n \text {, }
$$

the factor $K_{e}$ is given by

$$
K_{e}=\frac{1}{n}=\frac{1}{0.3}
$$

The alternating stress $S_{\text {alt }}$ from Eq. (C.17) is thus

$$
\mathrm{S}_{\text {alt }}=\frac{(17.470)}{(2)(0.3)}=292,450 \mathrm{pui} \text {. }
$$

From Fig. 1-9.2 of the Code, the allowable number of fatigue cycles $\mathbb{N}$ at $\mathrm{S}_{\mathrm{a}}=\mathrm{S}_{\text {alt }}=295,000 \mathrm{psi}$ is 60 . Because 50 cycles at operating conditions were postulated, the lug design is adequate except for not meeting the overload limitation. For this particular design the new requirement $\mathrm{S}_{\mathrm{nl}}^{* *} \leq 3 \mathrm{~S}_{\mathrm{m}}[\mathrm{Eq}$. (26) of the text] is thus necessary to prevent a potentially dangerous condition. 
LISTING OF THE COMPUTER PROGRAM LUGS (BASIC)

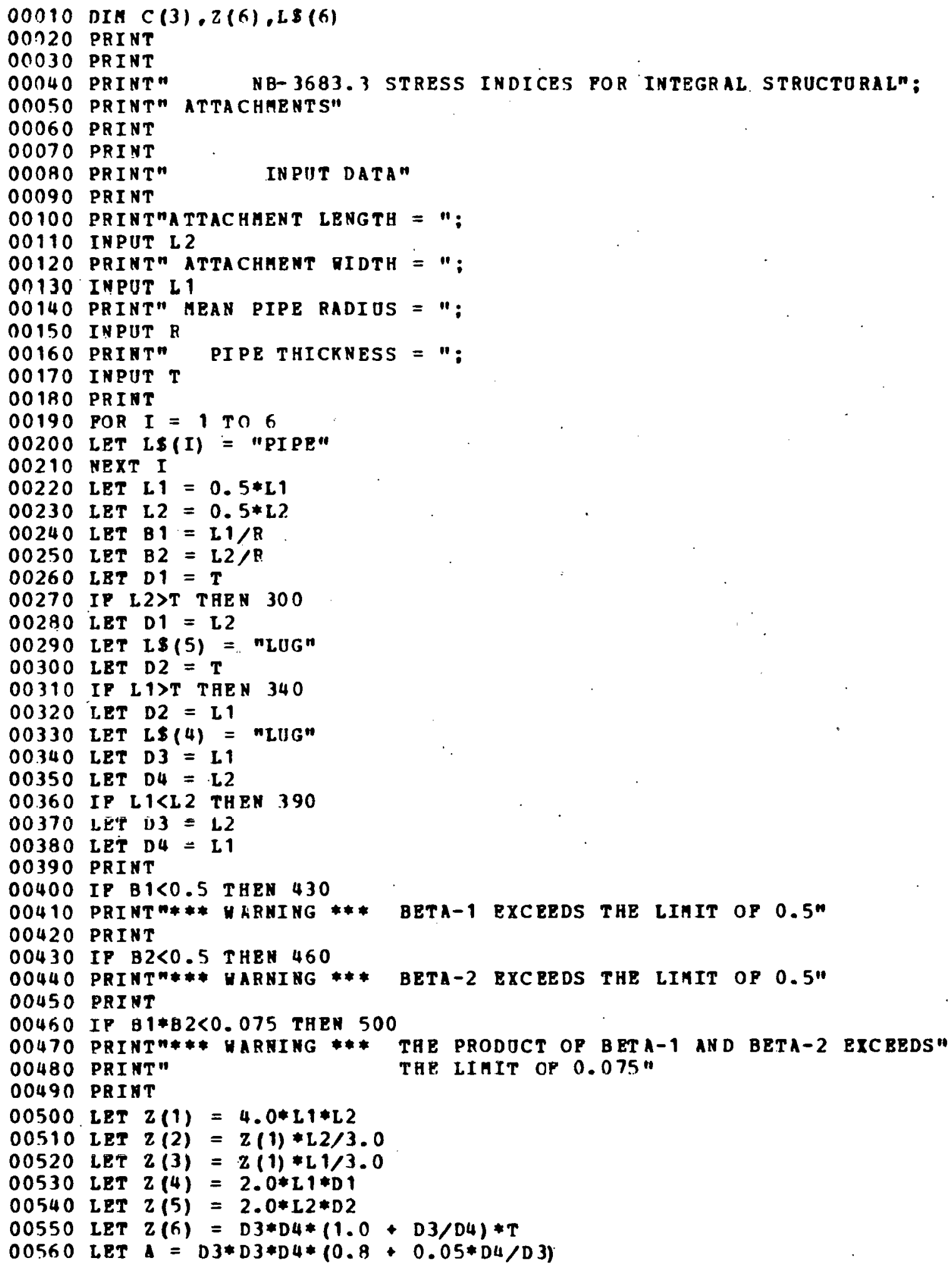




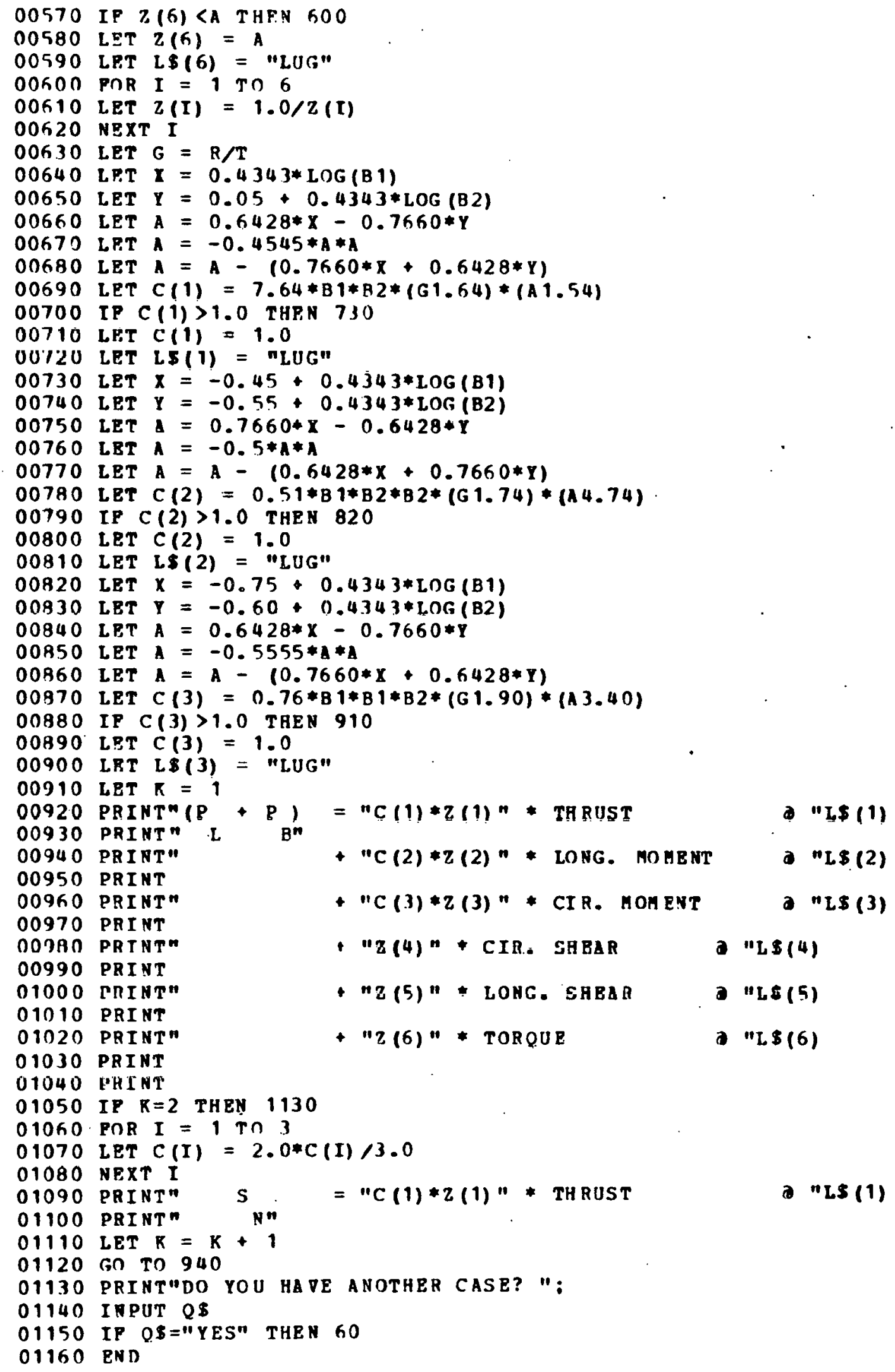


ORIVL-TM-42II

UC-79, $-79 \mathrm{~h},-79 \mathrm{k}$

INTERNAL DISTRIBUTION

1. S. E. Beall

2. M. Bender

3. S. E. Bolt

4. J. W. Bryson

5. J. R. Buchanan

6. J. P. Callahan

7. C. E. Childress

8. J. A. Clinard

9. J. M. Corum

10. W. B. Cottrell

11. F. L. Culler

12-16. W. G. Dodge

17. M. H. Fontana

18. A. P. Fraas

19. W. R. Gall

20-24. W. L. Greenstreet

25. R. C. Gwaltney

26. W. O. Harms

27. H. W. Hoffman

28. P. R. Kasten

29. K. C. Liu

30. R. N. Lyon

31. R. E. MacPherson
32. W. J. McAfee

33. H. C. McCurdy

34. J. G. Merkle

35. A. J. Miller

36-60. S. E. Moore

61. A. M. Pexry

62. T. W. Pickel

63. H. Postma

64. C. E. Pugh

65. R. A. Schmidt

66. M. R. Sheldon

67. J. E. Smith

68. I. Spiewak

69. D. A. Sundberg

70. D. B. Trauger

71. G. D. Whitman

72. G. T. Yahr

73. ORNL Patent Office

74-75. Central Research Library

76. Document Reference Section

77-82. Laboratory Records Department

83. Laboratory Records - Record Copy

\section{SUBCONTRACTORS AND CONSULTANTS}

84. A. J. Edmondson, University of Tennessee, Knoxville, TN

85. R. H. Gallagher, Cornell University, Ithaca, NY

86. J. K. Hayes, Combuetion Engineering, Chattanonga, TN

87. R. W. Holland, University of Tennessee, Knoxville, TN

88. A. T. Hopper, Battelle Memorial Institute, Columbus, $\mathrm{OH}$

89. L. E. Hulbert, Battelle Memorial Institute, Columbus, $\mathrm{OH}$

90. N. Krishnamurthy, Auburn University, Auburn, AL

91. R. L. Maxwell, University of Tennessee, Knoxville, TN

92. F. M. O'Hara, Oak Ridge, TN

93. E. T. Onat, Yale University, New Haven, CT

94. G. H. Powell, University of California, Berkeley, CA

95. Y. R. Rashid, General Electric Co., San Jose, CA

96-100. E. C. Rodabaugh, Battelle Memorial Institute, Columbus, of

101. W. F. Swinson, Auburn University, Auburn, AI

102. S. Y. Zamrik, Pennsylvania State University, University Park, PA

103. Z. Zudans, Franklin Institute, Philadelphia, PA 
104-105. Director, Division of Reactor Research and Development, U.S Atomic Energy Commission, Washington, D.C.

106. RRD Senior Site Representative, ORNL

107. Research and Technical Support Division, AEC-ORO, P. O. Box E, Oak Ridge, TN.

108. Patent Office, AEC, ORO

109-185. Nozzle Analysis and Nuclear Design Criteria - Piping-PumpsValves Programs Distribution

186-454. Given distribution as shown in TID-4500 under UC-79, UC-79h, and UC-79k 